Florida International University FIU Digital Commons

FIU Electronic Theses and Dissertations

University Graduate School

7-18-2008

\title{
Biohazard neutralization based on lipid technology
}

Edelmira Bosques

Florida International University

DOI: $10.25148 /$ etd.FI14051801

Follow this and additional works at: https://digitalcommons.fiu.edu/etd

Part of the Biomedical Engineering and Bioengineering Commons

\section{Recommended Citation}

Bosques, Edelmira, "Biohazard neutralization based on lipid technology" (2008). FIU Electronic Theses and Dissertations. 1771. https://digitalcommons.fiu.edu/etd/1771

This work is brought to you for free and open access by the University Graduate School at FIU Digital Commons. It has been accepted for inclusion in FIU Electronic Theses and Dissertations by an authorized administrator of FIU Digital Commons. For more information, please contact dcc@fiu.edu. 
Miami, Florida

A thesis submitted in partial fulfillment of the requirements for the degree MASTER OF SCIENCE in

BIOMEDICAL ENGINEERING

by

Edelmira Bosques 
To: Interim Dean Amir Mirmiran

College of Engineering and Computing

This thesis, written by Edelmira Bosques, and entitled Biohazard Neutralization Based on Lipid Technology, having been approved in respect to style and intellectual content, is referred to you for judgment.

We have read this thesis and recommend that it be approved.

Anthony J. McGoron

Chenzhong Li

Eric T. Crumpler, Major Professor

Date of Defense: July 18, 2008

The thesis of Edelmira Bosques is approved.

Interim Dean Amir Mirmiran

College of Engineering and Computing

Dean George Walker

University Graduate School

Florida International University, 2008 


\section{DEDICATION}

To my first mentors, my mom Carmen T. Bosques and my dad Leonardo Bosques. Thanks for teaching me the value of the studies, for always believing in my work, and for all your help and loving support through out my career. 


\section{ACKNOWLEDGMENTS}

"Knowledge is in the end based on acknowledgements". Ludwig Wittgenstein. I would like to thank my mentor Dr. Eric T. Crumpler, for his guidance, support, and his patience through the development of my thesis. I would like to recognize the help of Dr. Mc Goron and Dr. Li; for their availability, suggestions, and revisions for this thesis. Special thanks to Dr. Mathee, for opening the doors to her lab for me, for her assistance and for making me feel as part of her lab group. I would like to thank Diansy Zincke, Deepak Balasubramanian and Lisa Schneper, for their patience and absolute help at Dr. Mathees' lab. Also, to my labmates Zhiqi Zhang, Ronald Gutierrez, Soliany Pardo and Michael Becker for their unconditional help, suggestions and support though out the difficult times. I would also like to acknowledge Nanomaterials company for proving the grant that supported this research.

In addition to all of my friends and family in particular to Laura Andujar, Abdiel Torres, Evamariely García, Eduardo Sastre, Jaime Rivera, Zaida Salas, Enrique González, and Lourdes González, who supported me through hard-hitting moments by smoothing the tension with their sense of humor. Thanks to my brothers Leonardo A. Bosques and Gustavo Bosques for their loving support through out the distance. Also thanks to my uncle Guillermo Bosques and my aunt Angelica Bosques, for their unique support. Special thanks to Mohammed Goryawala, Misael del Valle, Adel Elsayed, José M. Villar, Javier González, Avani Mulchandani, Shrada Prabhulkar, Sridevi Nagaraja, Laura Causey, Karin Hsiao, and Barbara Traub for making me part of their everyday life and for becoming like a family to me. Special recognition to Karin, for dedicating of her time and effort for all the help in the edition this thesis. 


\section{ABSTRACT OF THE THESIS \\ BIOHAZARD NEUTRALIZATION BASED ON LIPID TECHNOLOGY \\ by}

Edelmira Bosques

Florida International University, 2008

Miami, Florida

Professor Eric T. Crumpler, Major Professor

A rapid detection and neutralization method for biowarfare agents would be a great biodefense in war times. With this purpose, liposomes were developed following the lipid film formation, rehydration, and extrusion procedure as the production method. $\mathrm{MgOCl}_{2}$ was encapsulated in the liposomes and it was tested with three different bacterium B. cereus; B. thuringiensis; and B. subtilis. For specificity, the liposomes were modified with a polyclonal antibody against $B$. cereus and B. subtilis. The liposomes were characterized using a Malvern Zetasizer Instrument, and the study revealed stability of the liposomes stored at $4^{\circ} \mathrm{C}$ for a period of 15 days. A live/dead assay revealed a significant reduction of bacterium incubated with $\mathrm{MgOCl}_{2}$-liposomes. Smaller reduction percentages, but yet significant, were observed with the $\mathrm{MgOCl}_{2}$-immunoliposomes. $\mathrm{A}$ colony growth assay revealed a significant reduction percentage for empty liposomes, $\mathrm{MgOCl}_{2}$-liposomes, and $\mathrm{MgOCl}_{2}$-immunoliposomes incubated with $\mathrm{B}$. thuringiensis. 


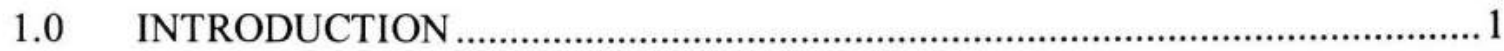

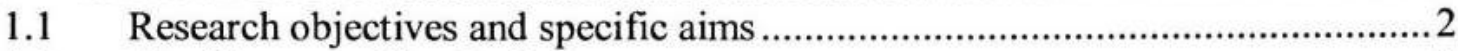

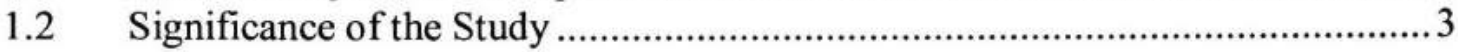

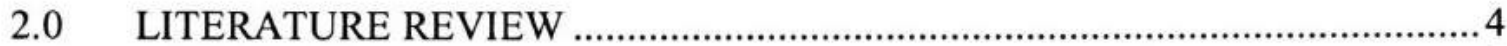

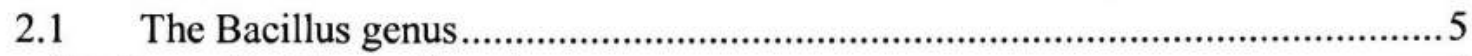

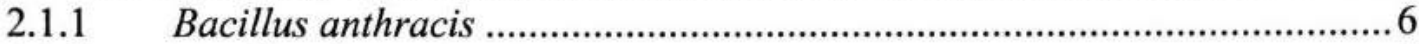

2.1.2 Bacillus thuringiensis ....................................................................... 7

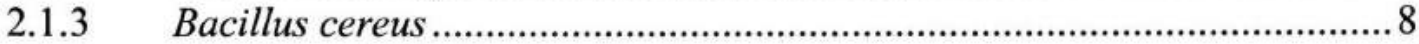

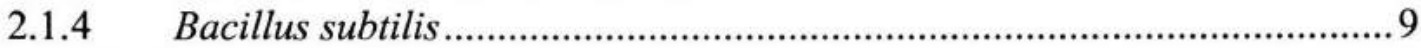

$2.2 \quad \mathrm{MgOCl}_{2} \quad$ Nanoparticles as Bactericidal Agent .............................................. 9

2.3 Liposomes and Liposome Technology ......................................................... 10

2.4 m-maleimidobenzoyl-N-hydoxysuccinimide ester (MBS) crosslinker .............15

$2.5 \quad$ 2-Iminothoilane (TRAUTS) crosslinker …...................................................... 15

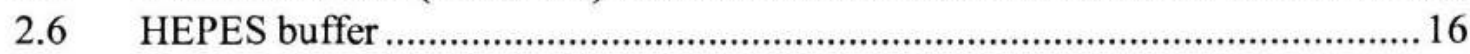

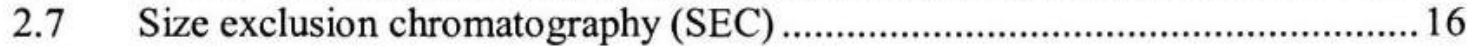

2.8 Minimum Inhibitory Concentration (MIC) assay.........................................16

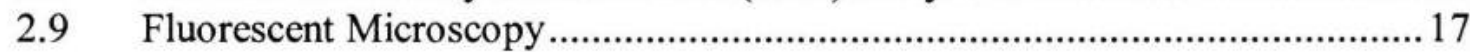

3.0 MATERIALS AND LIPOSOMES METHODS ............................................. 18

3.1 Materials necessary for the creation of the liposome solution .......................... 18

3.2 Method \#1, $100 \mathrm{~nm}$ liposome solution preparation ........................................ 18

3.3 Liposome film rehydration.......................................................................... 19

3.4 Making 20.0\% Trehalose 3mM HEPES solutions ......................................... 19

3.5 Extrusion Procedure using the $100 \mathrm{ml}$ extruder ...........................................2

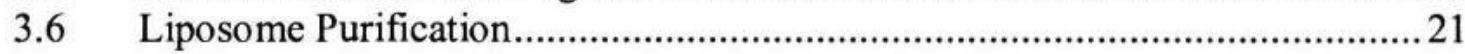

3.7 Method \#2, Streptavidin-Nanoparticle antibody Complex ..............................2

3.8 Streptavidin Coated Nanoparticle- MBS synthesis ........................................2

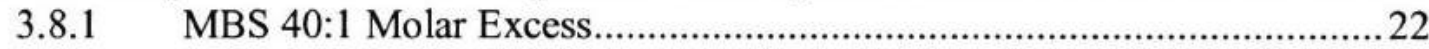

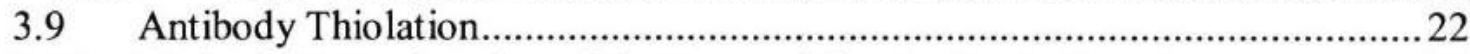

3.10 Method \#3, Conjugation of the Streptavidin- Antibody Complex …................2

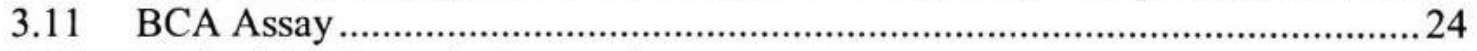

3.12 Method \#4, Bacteria Preparation ....................................................................2

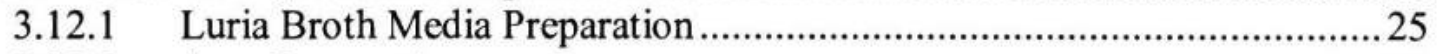

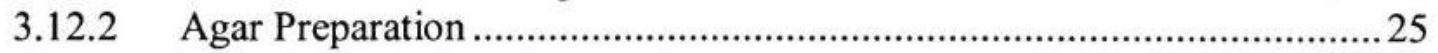

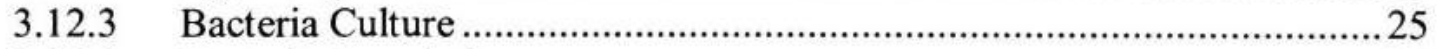

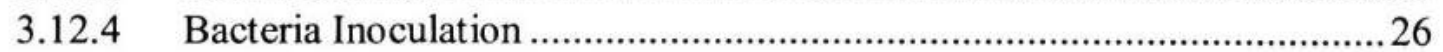

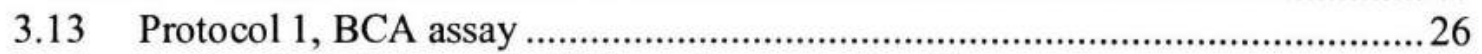

3.14 Protocol 2, Minimum Inhibitory Concentration Test .....................................22

3.15 Protocol 3, Colony Growth inhibition assay (CGA)........................................2 28

3.16 Protocol 4, Fluorescent Microscopy …............................................................ 30 


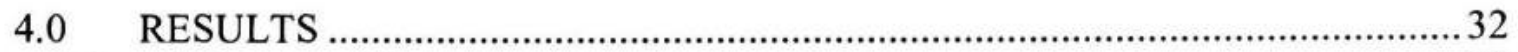

$4.1 \quad$ Liposome Size .................................................................................. 32

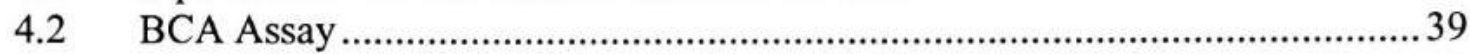

4.3 Minimum Inhibitory Concentration (MIC) assay .......................................4 40

4.4 Colony Growth Assay (CGA) ........................................................... 40

$4.5 \quad$ Live/Dead Assay.................................................................................. 43

4.5.1 Bacillus thuringiensis live/dead assay results.................................... 44

4.5.2 Bacillus cereus, live/dead assay results............................................... 46

4.5.3 Bacillus subtilis live/dead assay results............................................ 48

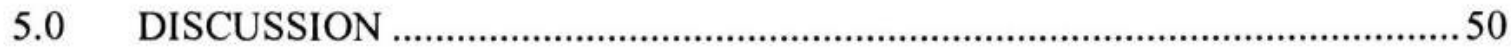

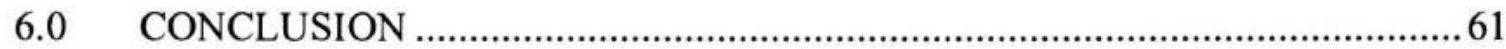

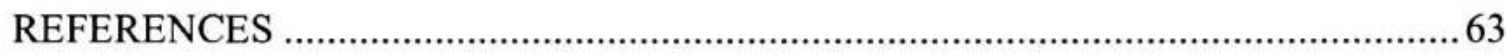

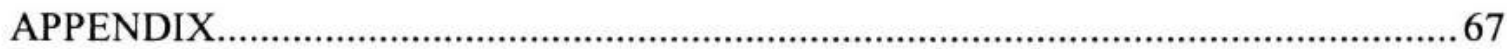




\section{LIST OF TABLES}

TABLE

PAGE

Table 1. Dilutions for enhanced BCA standard.

Table 2. 96-well plate and Petri dish contents for the MIC assay 28

Table 3. B. thuringiensis CGA reduction percentage

Table 4. B. thuringiensis CGA $\mathrm{P}$ values from a $\mathrm{t}$-Test for 1 hour

Table 5. B. thuringiensis CGA P values from a t-Test for 2 hours

Table 6. B. thuringiensis, live/dead assay reduction percentages at time $0 \mathrm{hr}$.

Table 7. B. thuringiensis, live/dead assay reduction percentages time $1 \mathrm{hr}$.

Table 8. B. thuringiensis, $\mathrm{P}$ values from $\mathrm{t}$-Test.

Table 9. B cereus, live/dead assay reduction percentage time $0 \mathrm{hr}$. 46

Table 10. B cereus, live/dead assay reduction percentage time $1 \mathrm{hr}$. 46

Table 11. B. cereus, $\mathrm{P}$ values from a t-Test 47

Table 12. Bacillus subtilis average reduction percentage at time $0 \mathrm{hr}$. 48

Table 13. Bacillus subtilis average reduction percentage at time $1 \mathrm{hr}$. 48

Table 14. B. subtilis, $\mathrm{P}$ values from a $\mathrm{t}-\mathrm{Test}$ 49 


\section{LIST OF FIGURES}

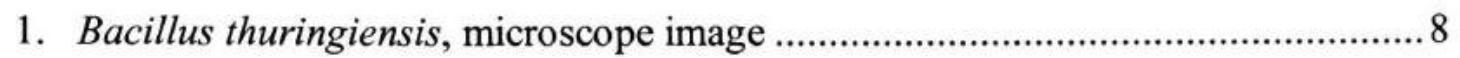

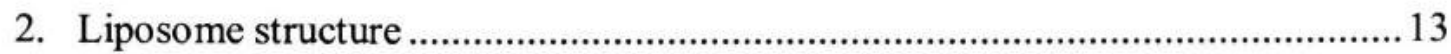

3. Surface modification of a liposome with antibodies ..........................................14

4. Schematic of the biotinylated liposome surface................................................2 23

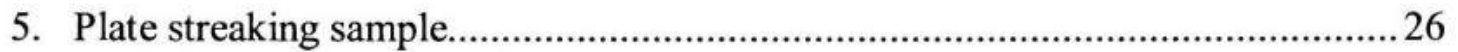

6. Colony growth assay (CGA) summary procedure …............................................ 30

7. Schematic representation of $\mathrm{MgOCl}_{2}$-immunoliposomes ..................................31

8. Empty liposomes size distribution curve on the $1^{\text {st }}$ day of storage at $4^{\circ} \mathrm{C} \ldots \ldots \ldots \ldots . . . .33$

9. Empty liposome size distribution curve after one week of storage at $4^{\circ} \mathrm{C} \ldots \ldots \ldots . . .33$

10. Empty liposome size distribution curve after 10 days of storage at $4^{\circ} \mathrm{C}$...............3 34

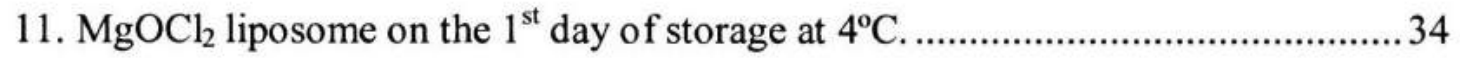

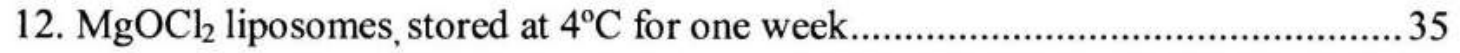

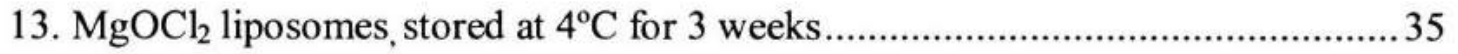

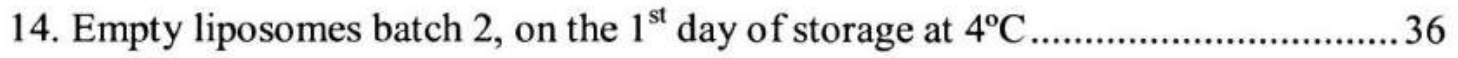

15. Empty liposomes batch 2, stored at $4^{\circ} \mathrm{C} 4$ weeks.............................................. 36

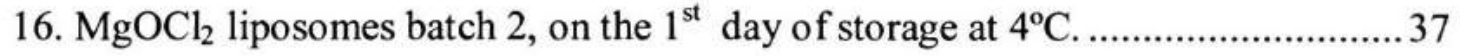

17. $\mathrm{MgOCl}_{2}$ liposomes batch 2 stored at $4^{\circ} \mathrm{C} 4$ weeks............................................... 37

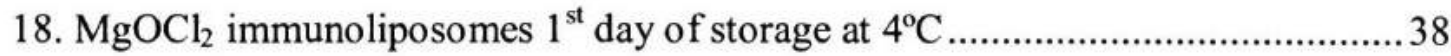

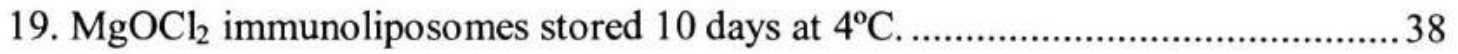

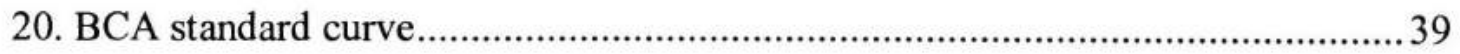

21. MIC for B. thuringiensis after 22 hours of incubation. ......................................40 


\subsection{INTRODUCTION}

Beginning on September 18, 2001, several mailed letters containing Bacillus anthracis (B. anthracis) spores were received at New York and Florida, by some media organizations. In October 2001, some members of the U.S. Congress also received mailed letters containing $B$. anthracis spores. Due to the $B$. anthracis intentional delivery in October 2001; 22 cases of pulmonary anthrax, caused by the inhalation of $B$. anthracis spores were reported. Five of the patients died due to a misdiagnosis of the disease (John A. Jernigan, Stephens et al. 2001). B. anthracis spores are acquired by the host through breaks in the skin, by inhalation or by ingestion (Committee to Update Science). It can cause different types of infections, which, if not detected before the fatal stage it will kill the host. The ease of spreading this bacteria spore as an aerosol, with the purpose of causing a massive infection, is attractive to terrorists. In addition, the spores are resistant to environmental changes and can persist in the environment for long periods, causing massive infections. Since all members of the Bacillus genus produce the endospores as part of their life cycle, it is impossible to determine the identity of the spores by casual or morphological examination (Swiecki 2006). In case of a bioattack, a fast and accurate way of neutralization is needed to prevent a massive infection.

In this study, liposomes were used as drug carriers of a bacterial neutralizing agent magnesium oxide chlorine $\left(\mathrm{MgOCl}_{2}\right)$ with the purpose of enhancing the bactericidal effect of $\mathrm{MgOCl}_{2}$ on bacterium, aiming the use of this system in the future as a defense against a biohazard. Since their discovery, liposomes have become popular drug carriers systems and have been enhanced in order to target specific sites of drug action such as the brain, cancer, and HIV-infected cells. The liposomes presented in this 
study are loaded with a neutralizing agent $\mathrm{MgOCl}_{2}$, capable of reducing Bacillus bacteria viability. In order to increase the specificity of these liposomes, their surface was modified with a polyclonal antibody specific to the spores and vegetative cells of the bacterium Bacillus cereus (B. cereus) and Bacillus subtilis (B. subtilis). The viability of the bacterium Bacillus cereus, Bacillus thuringiensis, and Bacillus subtilis was studied in the presence of the $\mathrm{MgOCl}_{2}$ liposomes and $\mathrm{MgOCl}_{2}$ immunoliposomes, compared to the viability of the bacteria in the presence of free $\mathrm{MgOCl}_{2}$.

\subsection{Research objectives and specific aims}

The primary purpose of this research is to develop a feasible method, capable of neutralizing Gram positive bacteria such as Bacillus cereus (B. cereus), Bacillus subtilis (B. subtilis) and Bacillus thuringiensis (B. thuringiensis). Also, it is proposed that the modified surface of a liposome with a polyclonal antibody against $B$. cereus and $B$. subtilis, has a better neutralization effect than a non targeted liposome. Due to the similarities between $B$. cereus and $B$. thuringiensis to $B$. anthracis, it is expected that the behavior of $B$. anthracis in contact with the immunoliposomes and with the drug loaded liposomes will be similar to that of the aforementioned Bacillus species. 
Specific Aims:

1. Development of surface modified $\mathrm{MgOCl}_{2}$-immunoliposomes with pseudospecificity toward B. cereus and B. subtilis bacterium.

2. Determine the efficacy of $\mathrm{MgOCl}_{2}$-immunoliposomes compared to $\mathrm{MgOCl}_{2}$ liposomes and free $\mathrm{MgOCl}_{2}$, against bacterial viability.

\subsection{Significance of the Study}

The significance of this study stems in the attempt to develop a neutralizing immunoliposome system for Bacillus bacterium. The neutralizing agent $\left(\mathrm{MgOCl}_{2}\right)$ that is able to damage or compromise the membrane cell wall of bacteria was encapsulated within liposomes and immunoliposomes. The development of this neutralization system brings the $\mathrm{MgOCl}_{2}$-liposomes and immunoliposomes technology closer to the development of a neutralization system capable of detecting and neutralizing the bacterium in a rapid and effective form. The bactericidal effect observed for the $\mathrm{MgOCl}_{2}$ immunoliposomes and $\mathrm{MgOCl}_{2}$ liposomes towards the bacterium B. thuringiensis, $\mathrm{B}$. subtilis, and B. cereus should be similar towards the bacteria $B$. anthracis. 


\subsection{LITERATURE REVIEW}

The Institute of Scientific Medicine affirmed that the United States is not yet prepared to deal with a bioterrorist attack. There are many bacterial threats that could risk citizens' health, for example Bacillus anthracis, Yersinia pestis, Francisella tularensis, and Clostridium botulinum (Nolen 2003).

Bacillus anthracis (B. anthracis), the bacteria that causes the disease anthrax, is the most dangerous bioweapon available to date. The three types of anthrax infections are cutaneous, gastrointestinal, and inhalation of anthrax. Cutaneous anthrax occurs when anthrax spores penetrate a wounded area of the skin; the infection will appear to be an insect bite. In approximately 2 days, the area will become a fluid filled vesicle, which will rupture and form an ulcer. As a peculiar characteristic, it will have a black necrotic area in the center. Approximately $20 \%$ of untreated cases of cutaneous anthrax result in death because the infection becomes systemic (Lenski). Gastrointestinal anthrax may be caused by consumption of contaminated meat from infected animals and it is characterized by an acute inflammation of the intestines. Mortality rates are around 25$60 \%$ (Weyant, Ezzell et al. 2001). Inhalation anthrax is the most lethal type of anthrax. It is the easiest way of spreading the bacteria in massive amounts. The symptoms of inhalation anthrax are similar to a common cold. If the patient is not treated within 36 hours he would enter into the lethal phase where chances of survival are not encouraging.

Current methods available to determine the presence of $B$. anthracis take up to 48 hours (Zayas 2006). For example, two types of tests performed to detect the presence of B. anthracis are the phenotypic identification of $B$. anthracis and antibody based methods. The phenotypic identification method requires blood cultures and requires 1-2 
days to provide a definitive identification and cultures from skin or lesions (Eduards 2006). Therefore, attention is focused on B. anthracis neutralization in a fast and precise way, with the purpose of biodefense.

\subsection{The Bacillus genus}

The family of Bacillus genus distinguishing feature is the production of endospores formed in the bacteria cell. Members of this group are Gram positive bacteria. Gram positive bacterium cell wall thickness is around $15-18 \mathrm{~nm}$ and it is composed of linear anionic polymers termed teichoic or teichuronic acids that are covalently linked to the peptidoglycan, giving the membrane cell wall support and protection (Lambert 2002; Kim, Farrah et al. 2007). The membrane wall is a bilayered structure and it has a selective permeable barrier that regulates the passage of substances into and out of the cell. Disorganization of the membrane by undesired or a foreign substance can cause loss of permeability of the membrane; therefore, causing its death (Lambert 2002). Liposomes composition is similar to the membrane cell wall and they can pass easier through it without being recognized as a foreign substance.

All Bacillus strains contain special mechanism of survival which is based in the production of endospores, the mechanism is activated in reaction to environmental alterations, such as exhaustion of essential nutrients or stress. The spores are resistant to extreme environmental changes and when the environmental stress is relieved, they germinate and become vegetative cells (K. Todar 2005). This mechanism of survival 
makes the elimination of these bacteria even more difficult, and a good bioweapon resource.

The Bacillus genus contains some toxins, which are generally water soluble and capable of interacting with the cell membrane. The toxins recognize specific receptors, which usually are lipids or another molecule that bound to the lipid bilayer. Bacterial toxins are able to cross lipid membranes, and induce pores to release cell nutrients or kill target cells by disrupting their membrane. The pore formation involves dynamic interactions between hydrophobic protein and hydrophobic lipid bilayers (Geny and Popoff 2006).

The use of liposomes to carry a bactericidal agent to treat Bacillus bacterium will provide a faster neutralization effect because they can pass through the membrane cell wall of the bacteria and the bactericidal toxins permeate the liposomes enhancing the drug release from the liposomes into the cell.

\subsubsection{Bacillus anthracis}

Bacillus anthracis (B. anthracis) is the bacteria that cause the disease anthrax. B. anthracis has a capsule, a proteinaceous surface layer, and several layers of peptidoglycan outside the surface of the plasma membrane. The capsule of $B$. anthracis contains poly-D-glutamic acid, which is a major determinant of its virulence. Of the Bacillus genus strains $B$. cereus and $B$. thuringiensis are the closest relatives to $B$. anthracis. Typically B. cereus and B. thuringiensis do not contain the poly-D-glutamic acid capsule (Sue, Hoffmaster et al. 2006). B. anthracis has some surface labels, which 
are the major components of the surface layer proteins EA1 and Sap. These labels can be identified by their specific antibodies anti-EAl and anti-Sap. In the presence of the capsule, there is an absence of immunolabels; therefore, it is suggested that the cell surface is inaccessible to the EA1 and anti-Sap antibodies. The presence of the antibodies could be due to the synthesis of these proteins prior to the complete coverage of the surface by the capsule or to leakage or bacterial lysis (Mesnage and Tosi-Courture 1998). This suggests that targeting the bacteria with an antibody EA1 or anti-Sap needs to be done before the bacterium is covered by the capsule. B. anthracis was not used for this thesis due to safety precautions, but the Bacillus strains that are described in the following section were used as a model of these bacteria.

\subsubsection{Bacillus thuringiensis}

Bacillus thuringiensis (B. thuringiensis) is an anaerobic Gram positive bacterium that is closely related to B. anthracis and B. cereus. These organisms are capable of producing endospores and differ mainly in their plasmids (Madigan and Martinko 2005). This bacterium has been used as the active ingredient of some insecticides because protein extracts of the bacteria react with the antiprotoxin antibody forming protein crystals of insecticidal protein toxins. These insecticidal proteins are called Cry proteins; these proteins have specific activities against Diptera, Cleoptera, and Lepidoptera species (Du 2005). From previous studies, Bacillus thuringiensis Cry4Ba toxin is shown to be capable of permeabilizing liposomes and forming ionic channels in receptor free planar lipid bilayers (Theeraporn Puntheeranurak 2005). 


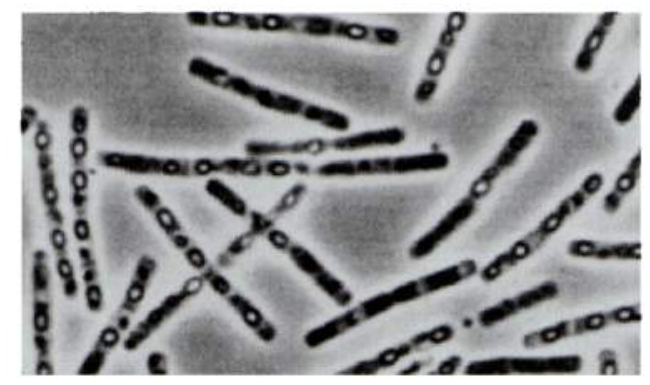

Figure 1. Bacillus thuringiensis, microscope image, observe the rod shape of the bacteria (K. Todar 2005).

\subsubsection{Bacillus cereus}

B. cereus is a spore forming bacteria that causes food spoilage and therefore foodborne illnesses (Koo, ForEgeding et al. 1998). This bacterium causes two different types of food poisoning, which are characterized by either emesis or diarrheal type of intoxication (Dietrich 1999). The first type of intoxication is the short- incubation period of 1-6 hours and is characterized by nausea, vomiting, and abdominal cramps. It resembles Staphylococcus aureus food poisoning in its symptoms and incubation period. B. cereus food poisoning occurs year-round and is without any particular geographic distribution. The short-incubation form is most often associated with fried rice that has been cooked and then held at warm temperatures for several hours. The second type is manifested primarily by abdominal cramps and diarrhea with an incubation period of 8 to 16 hours (K. Todar 2005). This bacterium has two different enterotoxin complexes, the nonhemolytic and hemolysin enterotoxins. Each of them is composed of three components with different molecular masses. The components of the hemolysin BL have been characterized and are required to produce maximum biological activity (Dietrich 1999). The surface protein for B. cereus is used for the production of an antibody from 
immunized animals and it is purified through SDS-PAGE (Hua 2002). B. cereus has an enzyme called Phospholipase C hydrolyzes with phosphatidylcholine, the major component in the liposomes used for this thesis.

\subsubsection{Bacillus subtilis}

Bacillus subtilis (B. subtilis) is not classified as a human threat, it may contaminate food but it rarely causes food poisoning. It is commonly found in the soil and has a protective endospore that protects it from extreme environments. B. subtilis has become adopted as a model organism; it is used as a Gram positive equivalent of $E$. coli.

\section{2 $\mathrm{MgOCl}_{2}$ Nanoparticles as Bactericidal Agent}

Nanotechnology is applying science and engineering knowledge for the design and production of new materials and devices on the nanoscale. Nanotechnology has the goal of increasing the ratio of the surface area per volume present in many nanoscale materials. Nanoparticles used as a bactericidal agent are able to cover the bacteria cells to a high extent bringing the drug's active form, at high concentration, in close proximity to the cell wall membrane were it acts by damaging the cell wall. This nanomaterial characteristic was used as the criteria of selection for liposome encapsulation. $\mathrm{MgOCl}_{2}$ nanoparticles are capable of damaging the bacterial cell wall because they can surround a higher surface area and create an alkaline environment that destroys the membrane cell wall of the bacteria (Stoimenov 2002). Therefore, $\mathrm{MgOCl}_{2}$ was encapsulated in the liposomes and tested for bactericidal effect. 
Stoimenov used $\mathrm{MgOCl}_{2}$ nanoparticles prepared through an aerogel procedure (AP) to test its bactericidal and sporicidal activity. AP-MgO nanoparticles possess many properties that are very desirable for a potent disinfectant. AP-MgO nanoparticles have the ability to absorb and retain for longer periods of time (in the order of months) significant amounts of chlorine and bromide. It is suggested that $\mathrm{AP}-\mathrm{MgO}$ nanoparticles can absorb $20 \mathrm{wt} \%$ chlorine. Furthermore, Koper showed that $\mathrm{AP}-\mathrm{MgO} / \mathrm{Cl}_{2}$ formulations are quite active as biocides, more so than free $\mathrm{Cl}_{2}$ or AP-MgO itself or commercially available microcrystalline $\mathrm{MgO}$ (Koper, Klabunde et al. 2002). In previous studies by Stoimenov, it has been proven that $\mathrm{AP}-\mathrm{MgO} / \mathrm{Cl}_{2}$ and $\mathrm{AP}-\mathrm{MgO} / \mathrm{Br}_{2}$ changed significantly the Escherichia coli, Bacillus subtilis, and Bacillus Megaterium cell wall (Stoimenov 2002). Chlorine action is dependent on $\mathrm{pH}$ and temperature. From the reaction of chlorine and water, one of the products is $\mathrm{HOCl}$, and $\mathrm{pH}$ levels are around 4.0-6.0. Microorganism killed by disinfectants are assumed to follow the CT concept, defined as the product of disinfectant concentration and time (Davis and Cornwell 1991).

\subsection{Liposomes and Liposome Technology}

Liposomes were discovered by A.D Bangham (Segota and Tezak 2006), who was performing blood clot research on the colloidal behavior of some phospholipids. Bangham found that phospholipids were capable of forming spheres in diluted aqueous solutions, and he described the liposomes as the smallest artificial vesicles that can be produced from natural nontoxic phospholipids and cholesterol (Segota and Tezak 2006). 
Since Bangham's discovery, liposomes are considered as highly versatile structures for research due to their many applications.

Liposomes can be used to encapsulate and deliver a chemical dissolved in an aqueous environment. Hydrophilic chemicals are entrapped in the aqueous compartments of the liposomes, whereas hydrophobic chemicals are incorporated into their lipid bilayers (Mugabe, Azghani et al. 2005) (see figure 2). For the purpose of this research a hydrophilic chemical $\mathrm{MgOCl} 2$ was used, and the liposomes entraped it in its aqueous compartment.

Liposomes have permeability properties similar to biological membranes, also they are non toxic and non immunogenic. Therefore, interest in these vesicles towards the study of the interactions between membrane lipids and biomolecule grew due to the possibility of their use as a model of biological membranes (Mugabe, Azghani et al. 2005; Eduards 2006; Segota and Tezak 2006). Liposomes can be characterized by size, number of layers, and surface charge (Segota and Tezak 2006). Liposome size can be controlled by decreasing the total energy in the dispersed system (Sabin, Prieto et al. 2006). Liposomes formed with phospholipids have high stability, but have no thermodynamic stability. They require some energy input provided by sonication, electrophoration or extrusion in order to form vesicles. Initially liposomes consist of several layers (multilamellar vesicles), which are removed as the extrusion process is performed to make them unilamellar encapsulating vesicles of a desired size (Segota and Tezak 2006). The extrusion procedure was the energy input method used for the development of the liposomes in this thesis and filter membranes of 100-80 nm were used in the procedure to make $100 \mathrm{~nm}$ liposomes. 
Phosphatidylcholine, liposomes are zwitterionic lipids, meaning that they have zero net charge and that they will repel each other providing colloidal stability to the phosphatidylcholine liposome system (Malmsten 2002). The membrane of the liposomes made for this thesis is mainly composed of phosphatidylcholine and Biotin-polyethylene glycol (PEG) and is "alloyed" with cholesterol (which is the basic constituent of cell membranes) to improve mechanical stability. This results in a stronger membrane with reduced permeability (Lasic 1998; Sederatou, Tsiourvas et al. 2000). Cholesterol in liposomes has been proven to enhance liposomes recognition due to the organization of the lipids and resulting in a higher lateral motility of the recognizable molecules in the liquid ordered phase (Sederatou, Tsiourvas et al. 2000).

The stability of the liposomes can be enhanced by the addition of a protective agent. In addition, the agent will help avoid aggregation and provide a longer storage time. The cryoprotectant trehalose is a non-reducing glucose disaccharide, which is found in many species of hydrobiotic organism. Trehalose is type of sugar that has been used to maintain the structural integrity and viability of certain biomaterials, and it was proven to be capable of maintaining liposome stability in solution for a longer period of time (Holovati and Acker 2007). Trehalose was used to increase the stability and storage time of the liposomes created for this thesis. 


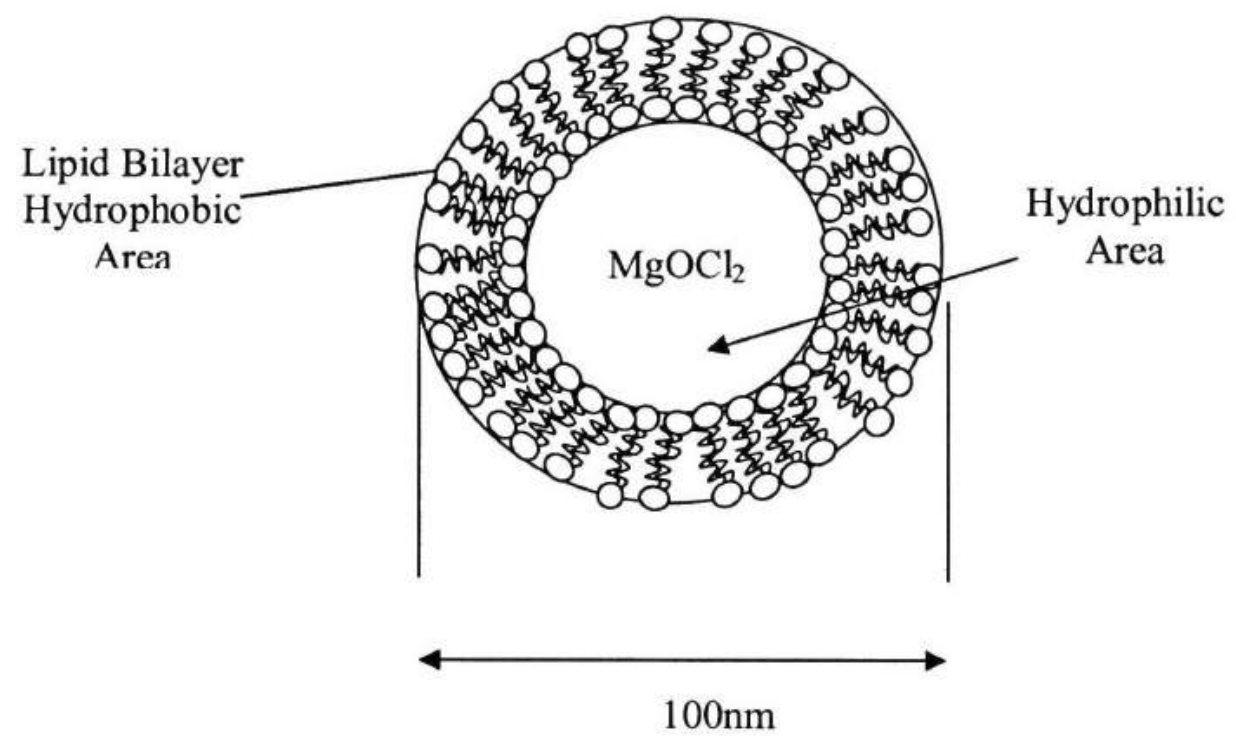

Figure 2. Liposome structure. Hydrophobic drugs can be entrapped within the liposome lipid bilayer. $\mathrm{MgOCl}_{2}$ is a hydrophilic molecule which was used as a neutralizing agent for the purposes of this thesis and was entrapped inside the aqueous area of the liposomes.

Liposomes are of great interest to pharmaceutical companies due the drug encapsulation capacity and the possibility of control of their delivery to a specific target in the body. Drug targeting by antibody-conjugated liposomes (immunoliposomes), see figure 3, represents a technology that has been applied to the targeting of specific sites of drug action, such as the brain, lung, cancer cells or cells of the immune system (Schnyder, Krahenbuhl et al. 2004). Site-specific targeting depends on the labeling of a liposome with an antibody and the high affinity between the antibody and its specific antigen. The use of antibodies in the surface of the liposomes may shorten the detection and neutralization time from days to hours (Koo, ForEgeding et al. 1998). The efficacy of the targeting depends on choosing the correct antibody to label the surface of the liposomes, and the specificity of the antigen against that antibody. The liposomes made for this application contain Biotin PEG- 2000. Biotin is used in many bioanalytical 
techniques specifically to form essential irreversible and specific linkages between biological molecules. Avidin and the homologous protein Streptavidin are tetrameric proteins, each can bind up to four molecules of biotin with high affinity (Lo 1999).

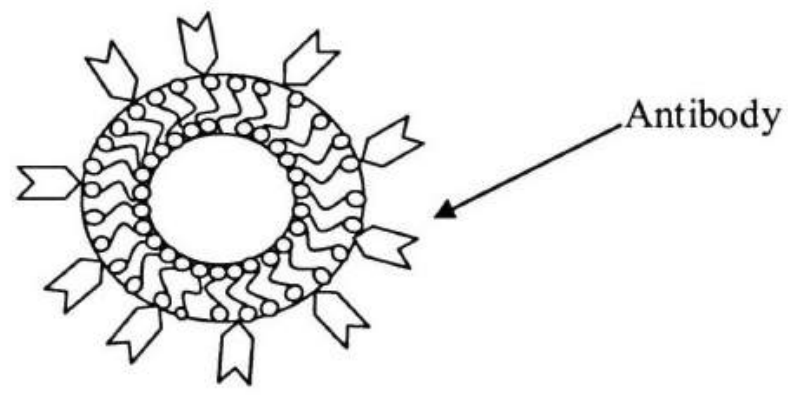

Figure 3. Surface modification of a liposome with antibodies to increase specificity.

Streptavidin has a high affinity for biotin $\left(\mathrm{Ka} \sim 10^{15} \mathrm{M}^{-1}\right)$ (Wolfgang Frey 1996) and will form a high strength bond between these two components. Streptavidin provides four binding sites for the biotin and for an antibody. This will help increase liposome specificity towards a specific target. The antibody used to demonstrate the specificity of the liposomes toward the bacterium in this thesis is a polyclonal antibody. Polyclonal antibodies come from different $\mathrm{B}$ cell lines and are a mixture of the immunoglobin molecules produced by those B cells. Each immunoglobin differs in the epitope that recognizes and the strength of the interaction. The recognition of the different epitopes in polyclonal antibodies may lead to the cross reaction with different species similar to the target antigen. The antibody to be used in this thesis is the rabbit antibody to Bacillus spores and is reactive with spores and vegetative cells of Bacillus cereus and Bacillus subtilis. As indicated by the manufacturer there is a possibility of cross-reaction with other Bacillus species. As a proof of principle, this polyclonal antibody is sufficient to 
demonstrate the identification of the bacteria by the $\mathrm{MgOCl}_{2}$-immunoliposomes, but for later applications, a monoclonal antibody against the target bacteria should be used.

\section{4 m-maleimidobenzoyl-N-hydoxysuccinimide ester (MBS) crosslinker}

MBS is a heterobifunctional cross linker that contains N-hydroxysuccinimide (NHS) ester and maleimide groups that allow covalent conjugation of amine-and sulfhydryl-containing molecule. NHS esters react with primary amines at $\mathrm{pH} 7-9$ to form amide bonds, while maleimides react with sulfhydryl groups at $\mathrm{pH}$ 6.5-7.5 to form stable thioether bonds (Pierce Company 2000). MBS was used to add an amine group in the $\mathrm{N}$ terminal of Streptavidin. This amine group will bind to the thiolated antibody used for this application of anti Bacillus spores.

\subsection{2-Iminothoilane (TRAUTS) crosslinker}

TRAUTS reagent is a thiolating agent used for the preparation of a disulfide conjugates (R. 1978). It was used to add a sulfhydryl to the amine group in the anti Bacillus spores antibody. The addition of the sulfhydryl group in the antibody will permit a conjugation with a Streptavidin protein creating a Streptavidin-antibody conjugate that will bind to the biotin surface of the liposomes created for this thesis. 


\subsection{HEPES buffer}

HEPES is a zwitterionic buffer, that do not bind Magnesium ions and is usually used to maintain $\mathrm{pH}$ of cell culture media. It was stored at ambient temperature and protected from light to avoid the production of hydrogen peroxide ions, and cell toxicity (Lepe-Zuniga, Jr. et al. 1987; Probes 2001; Incorporation 2006).

\subsection{Size exclusion chromatography (SEC)}

SEC is use to separate molecules by size. In general, a column is packed with porous particles of a defined pore size, and the SEC mobile phase is the solvent used to dissolve the sample for purification. The molecules that are too large to penetrate the pores elute in the void volume of the column, and high molecular weight molecules elude first. Smaller particle have a longer residence time since they interact more with the column packing and will elude after the larger molecules and therefore the larger molecules can separate and purified (Mori and Barth 1999).

\subsection{Minimum Inhibitory Concentration (MIC) assay}

MIC assay is a basic technique used to determine the minimum drug concentration required to kill a bacterial population in a period of 24 hours. The assay consists of adding known concentrations of free $\mathrm{MgOCl}_{2}$ to a certain volume of bacteria to determine the bactericidal effect compared to the $\mathrm{MgOCl}_{2}$-liposmes. 


\subsection{Fluorescent Microscopy}

Fluorescent microscopy is used for a rapid identification of bacterial antigens. A Live/Dead assay kit from Molecular Probes can asses the enzymatic activity of bacterial cells and is used to quantify the amount of live and dead bacteria in a sample. This kit provides two dyes, Syto 9 and propidium homodimer. Propidium homodimer dye penetrates the compromised membrane of the bacteria. The bacterium stained with this dye emits a red fluorescent color whereas the intact bacteria membrane will be dyed with Syto 9 and emit a green fluorescent light. Both can be observed under a fluorescent microscope with adequate filters (Probes 2004). The green fluorescent emission is due to the capacity of living cells to cleave the masked nonfluorescent form of green calcein fluorophore. The reason for the red fluorescence image in dead cells is the failure to exclude the ethidium homodimer dye from their nuclei (Ratner, Hoffman et al. 2004). 


\subsection{MATERIALS AND LIPOSOMES METHODS}

\subsection{Materials necessary for the creation of the liposome solution}

The materials necessary to make the lipid film are 1,2 Disteroyl-sn-Glycerol Phosphoethanolamine-N- Biotinyl [DSPE-PEG 2000] (from Avanti Polar Lipids) L- $\alpha$ Phosphatidylcholine (Egg-Chicken) (from Avanti Polar Lipids), Cholesterol (Ovine wool) (from Avanti Polar Lipids) and Chloroform ACS graded (from Fisher Scientific). The lipid film was hydrated with HEPES Buffer $1 \mathrm{M}$ (from Gibco Company) and the sugar Trehalose was used to preserve the lipids and the bactericidal agent $\mathrm{MgOCl}_{2}$ (from Nanomaterials Company).

\subsection{Method \#1, $100 \mathrm{~nm}$ liposome solution preparation}

To accomplish the first aim of this thesis, a liposome solution composed of 100 $\mathrm{nm}$ sized vesicles was created following Becker's protocol (Becker 2007). This was the first step leading to the accomplishment of Aim 1.

In order to prepare the lipid solution, $37.5 \mathrm{mg}$ of DSPE- PEG 2000 Biotin (solid), $87.5 \mathrm{mg}$ of $\mathrm{L}-\alpha-$ Phosphatidylcholine, and $6.5 \mathrm{mg}$ of cholesterol were weighted and dispensed into a round bottom flask. In the fume hood, $50 \mathrm{ml}$ of Chloroform were added and stirred in a round bottom flask for 1 minute to produce a well-mixed solution and to avoid any particle residue. After mixing, the liposome solution was placed in the rotary evaporator (rotovap) under low vacuum to assist the evaporation of the chloroform. The water bath of the rotatory evaporator was set at $40^{\circ} \mathrm{C}$, and the water bath of the circulator was set to $14^{\circ} \mathrm{C}$. The evaporation of the solvent was assisted by low vacuum, and the 
rotation was set to $155 \mathrm{rpms}$. The average time for the solvent to evaporate was one hour. The lipid film was immersed in liquid Nitrogen three times and it was placed in the lyophilizer for an overnight procedure.

\subsection{Liposome film rehydration}

The flask containing the lipid film was rehydrated by an addition of $35 \mathrm{~mL}$ HEPES buffer after the overnight lyophilization. The flask was placed in the rotatory evaporator, and the rotations were set at 100 RPM until the lipid film is completely dissolved in the HEPES (this process takes approximately 45minutes). After the lipid film was completely rehydrated, $13.0 \mathrm{mg} \mathrm{MgOCl}_{2}$ were added to the liposome solution. The liposome solution containing the $\mathrm{MgOCl}_{2}$ was placed in the rotatory evaporator at the same conditions previously mentioned for a period of 15 minutes to help the $\mathrm{MgOCl}_{2}$ dissolve. After the drug was dissolved in the liposome solution, the liposomes were ready for the extrusion procedure (Becker 2007).

\subsection{Making $20.0 \%$ Trehalose $3 \mathrm{mM}$ HEPES solutions}

A $3 \mathrm{mM}$ HEPES solution was prepared by adding $3 \mathrm{ml}$ of HEPES buffer to a 1000 $\mathrm{ml}$ volumetric flask and then filled to the $1000 \mathrm{ml}$ mark with distilled water. The $20.0 \%$ trehalose solution was prepared by adding $20.0 \mathrm{mg}$ of Trehalose to $100 \mathrm{ml}$ of $3 \mathrm{mM}$ HEPES in an Erlenmeyer flask. 


\subsection{Extrusion Procedure using the $100 \mathrm{ml}$ extruder}

Liposomes are not thermodynamically stable therefore will not form spontaneously (Lasic 1998). Extrusion of the liposomes in a $100 \mathrm{ml}$ extruder provided the required energy to the system for the formation of the vesicles. The $100 \mathrm{ml}$ extruder needed to be prepared before the extrusion procedure. The extruder parts were cleaned with water and Alconox anionic detergent and rinsed with 1M HEPES buffer. After the instrument parts were cleaned, an extrusion with Triton X was performed followed by ten HEPES buffer extrusions of $10 \mathrm{ml}$ to remove any liposome residual left in the extruder. After the extruder was cleaned, the water bath was allowed to heat to $42^{\circ} \mathrm{C}$ and $15 \mathrm{ml}$ of the liposomes were added into the extruder tank. The Argon tank and the valve that allows the flow of the Argon into the extruder (green valve) were opened and the valve that releases the pressure of the tank was closed and the pressure of the Argon tank was increased to $100 \mathrm{psi}$ or to the required pressure for the liposomes to start coming out of the extruder. This process continues until the liposome solution is completely extruded. The extrusion procedure was repeated 10 times with the $100 \mathrm{~nm}$ membrane, the membrane was replaced every 5 extrusions. After the tenth extrusion $1 \mathrm{ml}$ of $2 \%$ trehalose was added to the extruded liposomes. Ten extrusions were performed with the $80 \mathrm{~nm}$ membrane and the membrane was replaced after 5 extrusions, after the tenth extrusion $2 \mathrm{ml}$ of $10 \%$ of trehalose were added. Finally, 3 extrusions were performed with a $50 \mathrm{~nm}$ membrane and a sample of $1 \mathrm{ml}$ was placed in the Zetasizer Nano ZS (from Malvern Instruments Ltd.) for size measurement. If the size is in the range of $100-80 \mathrm{~nm}$, the liposomes are ready for the purification procedure. Otherwise, 5 more extrusions need to be performed using a $50 \mathrm{~nm}$ membrane, until the liposome size matched the 
desired size range. This liposome extrusion procedure was established by Michael Becker 2007 (Becker 2007).

\subsection{Liposome Purification}

Liposome purification was performed by size exclusion chromatography using a Sephadex G-50 column. To make the Sephadex-G50 columns, $25 \mathrm{~g}$ of Sephadex were swelled in $250 \mathrm{ml}$ of HEPES ( 1 Gram swells in $9-11 \mathrm{ml}$ of buffer) at room temperature for 3 hours or at $90^{\circ} \mathrm{C}$ for one hour. Glass wool was packed inside a $60 \mathrm{ml}$ syringe. It is necessary to pre-treat the glass wool for 15 minutes with HEPES buffer before packing it. The Sephadex-G50 column was placed at low vacuum and $10 \mathrm{ml}$ of liposome solution was added to the column for purification. The purified liposomes were recovered in a 50 $\mathrm{ml}$ Erlenmeyer flask and stored in the refrigerator at $4-8^{\circ} \mathrm{C}$. After the purification, the liposomes size was measured with a Zetasizer Nano ZS manufactured by Malvern Instruments Ltd.

\subsection{Method \#2, Streptavidin-Nanoparticle antibody Complex}

The development of the Streptavidin- Antibody complex is the second step leading to the accomplishment of Aim 1.

\subsection{Streptavidin Coated Nanoparticle- MBS synthesis}

A Streptavidin-MBS complex was developed by mixing $40 \mu 1$ of Streptavidin in $5 \mathrm{ml}$ of a $16.0 \mathrm{mM}$ HEPES solution ( $4.3 \mathrm{ml}$ of dionized water, and $0.7 \mathrm{~mL}$ HEPES) in a 
$15 \mathrm{ml}$ flask. A 40:1 molar excess of MBS solution was added to the diluted Streptavidin by adding $200 \mu$ l of MBS solution.

\subsubsection{MBS 40:1 Molar Excess}

Following the instructions from the Pierce company protocol; $3.14 \mathrm{mg}$ of MBS was dissolved in $1 \mathrm{~mL}$ of DMSO to make a $10 \mathrm{mM}$ MBS solution. The preparation of the molar excess consists of adding $40 \mu \mathrm{l}$ of Streptavidin to the MBS solution. A 40:1 molar excess of MBS solution is prepared by adding $200 \mu 1$ of MBS to $40 \mu 1$ of Streptavidin solution. The MBS-Streptavidin Complex was purified following the standard protocol of a 30 Centriprep Ultrafiltration Device from Millipore.

\subsection{Antibody Thiolation}

The antibody needs to be thiolated before it can bind to the available maleimide in the Streptavidin-MBS complex. A 40:1 molar excess of TRAUTS powder, was prepared by dissolving $1 \mathrm{mg}$ of TRAUTS in $200 \mu \mathrm{l}$ of HEPES. The antibody (rabbit antiBacillus spores) $(40 \mu \mathrm{l})$ was diluted in $2 \mathrm{ml}$ of HEPES 1M. A 40:1 molar excess was added to the diluted antibody with the buffer flask, and it was placed in a gently stirred water bath at room temperature for one hour. After the antibody thiolation, purification by size exclusion chromatography was performed in a Sephadex $25-\mathrm{G}$ column. 


\subsection{Method \#3, Conjugation of the Streptavidin- Antibody Complex}

The third and final step for the accomplishment of Aim 1 consists of the formation of the Streptavidin-MBS complex and the conjugation of the complex with the liposomes.

In order to obtain the Streptavidin-Antibody complex, $150 \mu 1$ of the StreptavidinMBS Complex were mixed with $500 \mu \mathrm{l}$ of the antibody-TRAUTs into a $15 \mathrm{ml}$ conical tube and vortexed it for 20 seconds. This complex was left in a water bath overnight to permit the conjugation to take place.

The $\mathrm{MgOCl}_{2}$-immunoliposomes were made with a 1:1 ratio of the $\mathrm{MgOCl}_{2}$ liposomes and the Streptavidin-Antibody complex. The $\mathrm{MgOCl}_{2}$-immunoliposomes inside the $15 \mathrm{ml}$ flask were placed in a water bath at room temperature, and stirred for 30 minutes to ensure the reaction took place.

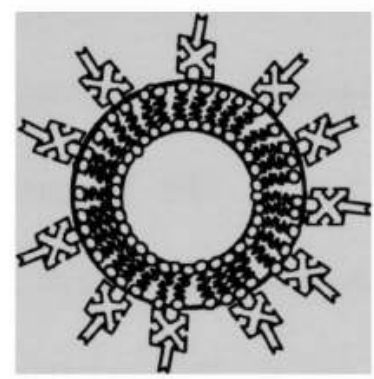

Figure 4. Schematic of the biotinylated liposome surface, modified with the Streptavidin- Antibody Complex, where represents Streptavidin, ITrepresents the anti-Bacillus spores antibody, $\square$ and represents the PEG-2000 Biotin. 


\subsection{BCA Assay}

To determine the concentration of proteins (antibody) in the Streptavidinantibody complex, a BCA assay was performed. This assay is required for the quantification of the total protein attached to the surface of the liposome (Streptavidin and the anti Bacillus spores antibody).

The BCA assay is based on the reduction of $\mathrm{Cu}^{+2}$ to $\mathrm{Cu}^{+1}$ by proteins. The reduction is proportional to the protein present in a solution. The biuret product that is in contact with the $\mathrm{Cu}^{+1}$ turns violet is an indicator of protein presence (Pierce Company 2006). The assay comes with to reagents that mixed together in a $50: 1$, A to B. This mixture is called the working solution. This solution makes the samples change from clear to color purple when protein is present. The manufacturer standard protocol is followed to create the standard solutions in order to obtain the absorbance values in the spectrophotometer. The obtained data was used to determine the protein concentration. The absorbance of the standard and the Streptavidin-Antibody sample was determined in

a TECAN spectrophotometer at $595 \mathrm{~nm}$. A standard curve of absorbance vs. concentration was created in Microsoft Excel. With the standard curve, the values of the absorbance obtained for the Streptavidin-Antibody complex were used to find the total protein concentration in this complex.

\subsection{Method \#4, Bacteria Preparation}

In order to test the $\mathrm{MgOCl}_{2}$-immunoliposomes to accomplish Aim 2 a standard protocol of bacteria preparation was followed as described in the next section. 


\subsubsection{Luria Broth Media Preparation}

Fresh Luria Broth bacteria media was made by adding $20 \mathrm{~g}$ of Luria Broth (LB) to $1000 \mathrm{ml}$ of distilled water into $2000 \mathrm{ml}$ Erlenmeyer flask. This solution was stirred in a stirring plate at high velocity until a homogeneous solution was observed. After the solution was prepared, it was placed into the autoclave equipment for a period of 50 minutes in the liquid cycle.

\subsubsection{Agar Preparation}

As recommended in the standard protocol for agar preparation, $40 \mathrm{mg}$ of agar powder was added to $1000 \mathrm{ml}$ of dionized water. The solution was well mixed with a magnetic stirrer for 15 minutes. The agar solution was placed in the autoclave for 25 minutes. After removing from the autoclave, the solution was placed in the magnetic stirrer mixer to cool down the solution. After the solution is warm enough, it was poured in the agar plates.

\subsubsection{Bacteria Culture}

Basic bacteria culture procedures like bacteria streaking and bacteria inoculation was followed. Bacteria stocks were placed in a $-80^{\circ} \mathrm{C}$ freezer; the vials were taken from the freezer; and was warmed in the hands. With a pipette tip, obtain some cells from the freeze stock and streak in the agar plate as shown in figure 5. 


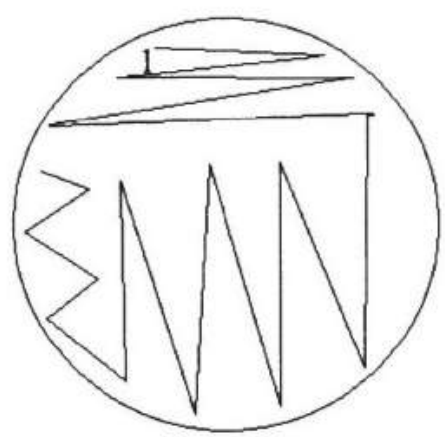

Figure 5. Plate streaking sample. The number 1 indicates the streaking starting point

After streaking the desired number of culture dishes, the plates were placed inside an incubator at physiological conditions $\left(37^{\circ} \mathrm{C}\right)$ overnight.

\subsubsection{Bacteria Inoculation}

Sixteen hours after the streaking incubation, the culture dishes were removed from the incubator and placed in the bench top until a selection of one isolated colony was made. The selected colony was scraped with a round tip and then mixed in a $50 \mathrm{ml}$ Erlenmeyer flask with $10 \mathrm{ml}$ of Luria Broth. The bacterial solution was placed inside a shaking incubator at $37^{\circ} \mathrm{C}$ overnight. A bacteria concentration was determined using an Optical Density Spectrophotometer analysis at $600 \mathrm{~nm}$. From this concentration, 4 serial dilutions of 1:10 were made to reach theoretical concentration of $1 \times 10^{5}$ cells $/ \mathrm{ml}$.

\subsection{Protocol 1, BCA assay}

The most important step to develop a successful BCA assay to obtain the unknown amount of protein in solution, is to generate a standard curve of Absorbance vs. 
Concentration. The standard solutions were prepared following the instructions provided by the manufacturer in Table 1. Three samples of twenty five microliters each of the standard dilutions were pipetted into a 96-well microplate with $200 \mu \mathrm{l}$ of working reagent. The plate was then shaken for 30 seconds and incubated at $60^{\circ} \mathrm{C}$ for 30 minutes. After 30 minutes of incubation the microplate was cooled at room temperature for 30 minutes. The absorbance reading was measured in the Tecan instrument at $595 \mathrm{~nm}$. An Absorbance vs. Concentration curve was performed with the averages of the measured absorbance values subtracted to the blank standard measurement at $595 \mathrm{~nm}$.

\begin{tabular}{|l|c|c|c|}
\hline Vial & Volume of Diluent & Volume and Source of BSA & Final BSA concentration \\
\hline $\mathrm{A}$ & $720 \mu \mathrm{l}$ & $80 \mu \mathrm{l}$ of stock & $200 \mu \mathrm{g} / \mathrm{ml}$ \\
\hline $\mathrm{B}$ & $300 \mu \mathrm{l}$ & $500 \mu \mathrm{l}$ of vial A dilution & $125 \mu \mathrm{g} / \mathrm{ml}$ \\
\hline $\mathrm{C}$ & $160 \mu \mathrm{l}$ & $640 \mu \mathrm{l}$ of vial B dilution & $100 \mu \mathrm{g} / \mathrm{ml}$ \\
\hline $\mathrm{D}$ & $400 \mu \mathrm{l}$ & $400 \mu \mathrm{l}$ of vial C dilution & $50 \mu \mathrm{g} / \mathrm{ml}$ \\
\hline $\mathrm{E}$ & $400 \mu \mathrm{l}$ & $400 \mu \mathrm{l}$ of vial D dilution & $25 \mu \mathrm{g} / \mathrm{ml}$ \\
\hline $\mathrm{F}$ & $800 \mu \mathrm{l}$ & 0 & $0 \mu \mathrm{g} / \mathrm{ml}=\mathrm{Blank}$ \\
\hline
\end{tabular}

Table 3-1. Dilutions for enhanced BCA standard. Preparation of diluted albumin (BSA) standards dilution scheme for enhanced protocol microplate (working range 200-5 $\mu \mathrm{g} / \mathrm{ml}$ ) modified from Thermo Scientific Pierce Protein Research Products, protocol.

\subsection{Protocol 2, Minimum Inhibitory Concentration Test}

In order to determine the $\mathrm{MgOCl}_{2}$ liposomes effectiveness compared to the free drug at different concentration effectiveness, a Minimum Inhibitory Concentration assay was performed. $\mathrm{MgOCl}_{2}$ was diluted with $1 \mathrm{M}$ HEPES buffer to create solutions at concentrations of $2 \mathrm{M}, 1 \mathrm{M}, 0.5 \mathrm{M}, 30 \mathrm{mM}, 3 \mathrm{mM}, 1.5 \mathrm{mM}, 0.75 \mathrm{mM}, 0.3 \mathrm{mM}, 0.15 \mathrm{mM}$, and $0.075 \mathrm{mM}$. 
B. thuringiensis cultured overnight was diluted 5 times to a theoretical cell concentration of $1 \times 10^{5}$ cells $/ \mathrm{ml}$. Optical density measurements at $600 \mathrm{~nm}$ were recorded. One hundred and fifty microliters of the diluted bacteria was placed inside a 96-well plate and mixed with $150 \mu \mathrm{l}$ of the different $\mathrm{MgOCl}_{2}$ solutions. At time $0,100 \mu \mathrm{l}$ of the bacterial solutions were plated in a Petri Dish. The 96-well plate was placed inside a shaking incubator at physological conditions for a period of 22 hours. After 22 hours $100 \mu 1$ of the 96-well plate were plated in a Petri Dish and incubated at physiological conditions for 8 hours to observe the bacterial growth.

The 96-well plate and Petri dishes were filled and identified as described in Table 2.

\begin{tabular}{|c|c|}
\hline Plate Identification & Contents \\
\hline A & HEPES $+B$. thuringiensis \\
\hline B. & $2 \mathrm{M} \mathrm{MgOCl}_{2}+B$. thuringiensis \\
\hline C. & $1 \mathrm{M} \mathrm{MgOCl}{ }_{2}+B$. thuringiensis \\
\hline $\mathrm{D}$ & $0.5 \mathrm{M} \mathrm{MgOCl} l_{2}+B$. thuringiensis \\
\hline $\mathrm{E}$ & $30 \mathrm{mM} \mathrm{MgOCl}{ }_{2}+B$. thuringiensis \\
\hline $\mathrm{F}$ & $3 \mathrm{mM} \mathrm{MgOCl}{ }_{2}+B$. thuringiensis \\
\hline G & $1.5 \mathrm{mM} \mathrm{MgOCl}{ }_{2}+B$. thuringiensis \\
\hline $\mathrm{H}$ & $0.75 \mathrm{mM} \mathrm{MgOCl}_{2}+B$. thuringiensis \\
\hline A6 & $0.3 \mathrm{mM} \mathrm{MgOCl}_{2}+B$. thuringiensis \\
\hline B6 & $0.15 \mathrm{mM} \mathrm{MgOCl}_{2}+B$. thuringiensis \\
\hline C6 & $0.075 \mathrm{mM} \mathrm{MgOCl}_{2}+B$. thuringiensis \\
\hline D6 & $\mathrm{MgOCl}_{2}$ liposomes $+B$. thuringiensis \\
\hline
\end{tabular}

Table 3-2. 96-well plate and Petri dish contents for the minimum growth concentration assay.

\subsection{Protocol 3, Colony Growth inhibition assay (CGA)}

This assay was used to accomplish aim 2 to quantify the effect of the $\mathrm{MgOCl}_{2}-$ immunoliposomes and $\mathrm{MgOCl}_{2}$ liposomes towards B. thuringiensis. 
Bacillus thuringiensis was streaked and inoculated using standard protocol described above. A $100 \mu 1$ sample of each bacterium strain was taken from the flask inoculated overnight, and diluted with $900 \mu 1$ of Luria Bertani (LB) broth. Five hundred micro liters of the diluted sample were placed in a $1 \mathrm{~cm}^{3}$ cuvette. An optical density analysis was taken at $600 \mathrm{~nm}$ wavelength to determine the original bacteria concentrations. Four serial dilutions of 1:10 were performed. The diluted bacteria were divided in four $15 \mathrm{ml}$ flasks. Flask number four was filled with $2 \mathrm{ml}$ of the fourth dilution (containing $2.5 \mathrm{ml}$ of third dilution plus $22.5 \mathrm{ml}$ of Luria Broth). A quantity of $1.5 \mathrm{ml}$ of HEPES buffer was added to $15 \mathrm{ml}$ flask number one, the same amount of empty liposomes, $\mathrm{MgOCl}_{2}$ liposomes, and $\mathrm{MgOCl}_{2}$-immunoliposomes were added to flask number 2, 3, and four respectively. The same solutions prepared for B. cereus were prepared for the bacteria $B$. thuringiensis and $B$. subtilis. Two 1:10 serial dilutions were performed in order to obtain less than 300 colonies in the plates. The control plates of $B$. cereus and B. thuringiensis contain $100 \mu 1$ of each of the flasks prepared in four different Petri dishes at time zero. After one hour of incubation, $100 \mu 1$ of each flask was plated in four different Petri dishes. After three hours of incubation, $100 \mu 1$ of each of the solutions was plated onto four different plates. The same procedure was repeated for $B$. thuringiensis, but only with the difference of control plate containing $100 \mu$ of each solution. All the plates were incubated overnight at $37^{\circ} \mathrm{C}$. 


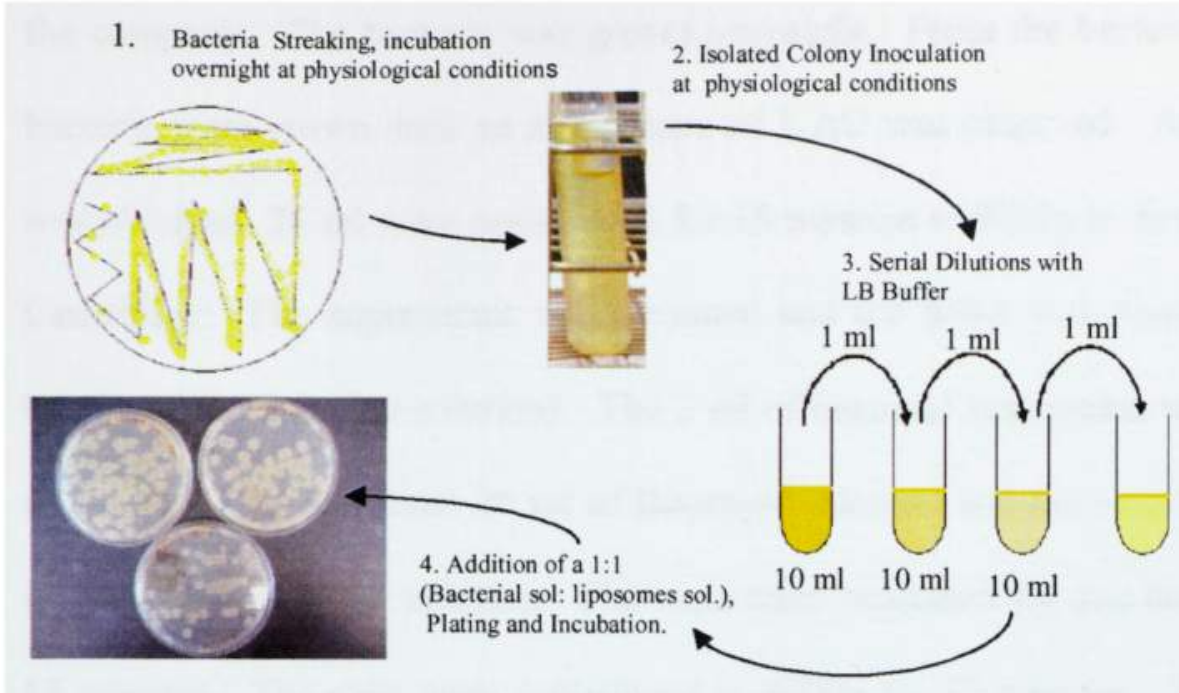

Figure 6. Colony growth assay (CGA) summary procedure. 1. Bacteria Streaking schematic, 2. One isolated colony from the streaked plate is inoculated overnight in LB broth at physiological conditions. 3. Five serials dilutions were performed in order to have approximately $1 \times 104 \mathrm{cells} / \mathrm{ml}$, a 1:1 ratio (Bacterial solution: HEPES, Empty liposomes, $\mathbf{M g O C l}_{2}$ liposomes, $\mathbf{M g O C l}_{2}$ immunoliposomes and $3 \mathrm{mM} \mathrm{MgOCl} \mathrm{M}_{2}$ in five different vials). 4. At time 0 hours $100 \mu \mathrm{l}$ of the solutions prepared in step 3 were plated in petri dishes, the solutions were incubated at physiological conditions for two hours and plating were performed for each hour. In a period of 6-8 hours the colonies become visible and the CFU count was performed.

\subsection{Protocol 4, Fluorescent Microscopy}

To identify the effect in the membrane cell wall of the bacteria caused by the $\mathrm{MgOCl}_{2}$ liposomes and the $\mathrm{MgOCl}_{2}$ immunoliposomes a live/dead assay for cell viability was performed. The bacteria samples in contact with the $\mathrm{MgOCl}_{2}$ liposomes and the $\mathrm{MgOCl}_{2}$-immunoliposomes were dyed with the backlight kit $\mathrm{L} 7012$ from Molecular Probes that contain propidium iodide and Syto-9. If the membrane cell wall is damaged, propidium iodide will enter inside the cell and bind to nucleic acid. This will produce the red image as an indication of dead or damaged cell. In contrast, Syto-9 will make a green fluorescent image as a result of the labeling of the dyed nucleic acids in the bacteria without damage in the membrane cell wall. The protocol followed was as provided by 
the company. The bacteria was grown overnight. From the bacteria culture, $30 \mathrm{ml}$ of bacteria were grown until an absorbance of $1 \mathrm{AU}$ was observed. After this absorbance was obtained, $25 \mathrm{ml}$ were centrifuged for 15 minutes at $9000 \mathrm{~g}$ in Sorval RT 6000 Series Centrifuge. The supernatant was decanted and the pellet was resuspended in $2 \mathrm{ml}$ of $0.85 \%$ of $\mathrm{NaCl}$ (saline solution). The $2 \mathrm{ml}$ of bacterial suspension was divided into two vials. One vial contained $20 \mathrm{ml}$ of Isopropyl Alcohol and the second vial contained 20 $\mathrm{ml}$ of $0.85 \%$ of saline solution. The vials were incubated for one hour and mixed every 15 minutes. The cells were centrifuged at $9000 \mathrm{~g}$ for 15 minutes. The supernatant was decanted from both vials and the pellet was re-suspended in $20 \mathrm{ml}$ of the $0.85 \%$ saline solution. The centrifugation procedure was repeated for the last time at the same conditions previously mentioned. The supernatant was decanted and the pellet was resuspended. The bacterial concentration was adjusted to $1 \times 10^{8}$ cells $/ \mathrm{ml}$ and it was stained with a mixture of the propiduim iodine and Styo 9. It was then observed under the fluorescent microscope.

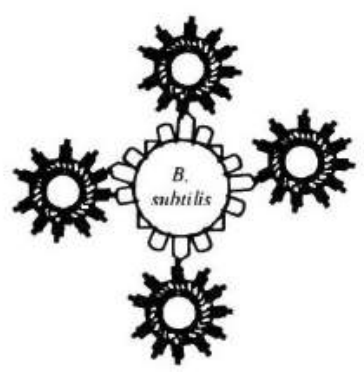

Figure 7. Schematic representation of $\mathrm{MgOCl}_{2}$-immunoliposomes attached to the antigens of $B$. subtilis 


\subsection{RESULTS}

\subsection{Liposome Size}

Liposome size measurements were performed in the Malvern Zeta Sizer. The liposome size varied between $50 \mathrm{~nm}$ and $500 \mathrm{~nm}$ with averages size of $100-149 \mathrm{~nm}$ (Figures 8-17). The liposomes were kept at $4^{\circ} \mathrm{C}$ and weekly size distribution test readings were performed in the Malvern Zetasizer to determine the stability of the liposomes in solution. The polydispersity index of the empty liposome solution doubled after a week but remained stable for a period of three weeks. The polydispersity index for $\mathrm{MgOCl}_{2}$ liposomes remained stable for three weeks. In the third week of storage the $\mathrm{MgOCl}_{2}$ liposomes size increased suggesting liposome swelling or aggregation. On the third week empty liposomes size and polydispersity also increased.

$\mathrm{MgOCl}_{2}$ liposomes and empty liposomes at 4 weeks of storage at $4^{\circ} \mathrm{C}$, showed a polydispersity index (PdI) of above 0.2 , and more than one peak in the size distribution curve. The $\mathrm{MgOCl}_{2}$ liposomes with the antibody attached to its surface showed a polydispersity index of above 0.2 and a second peak on the size distribution curve after one week of storage at $4^{\circ} \mathrm{C}$. 


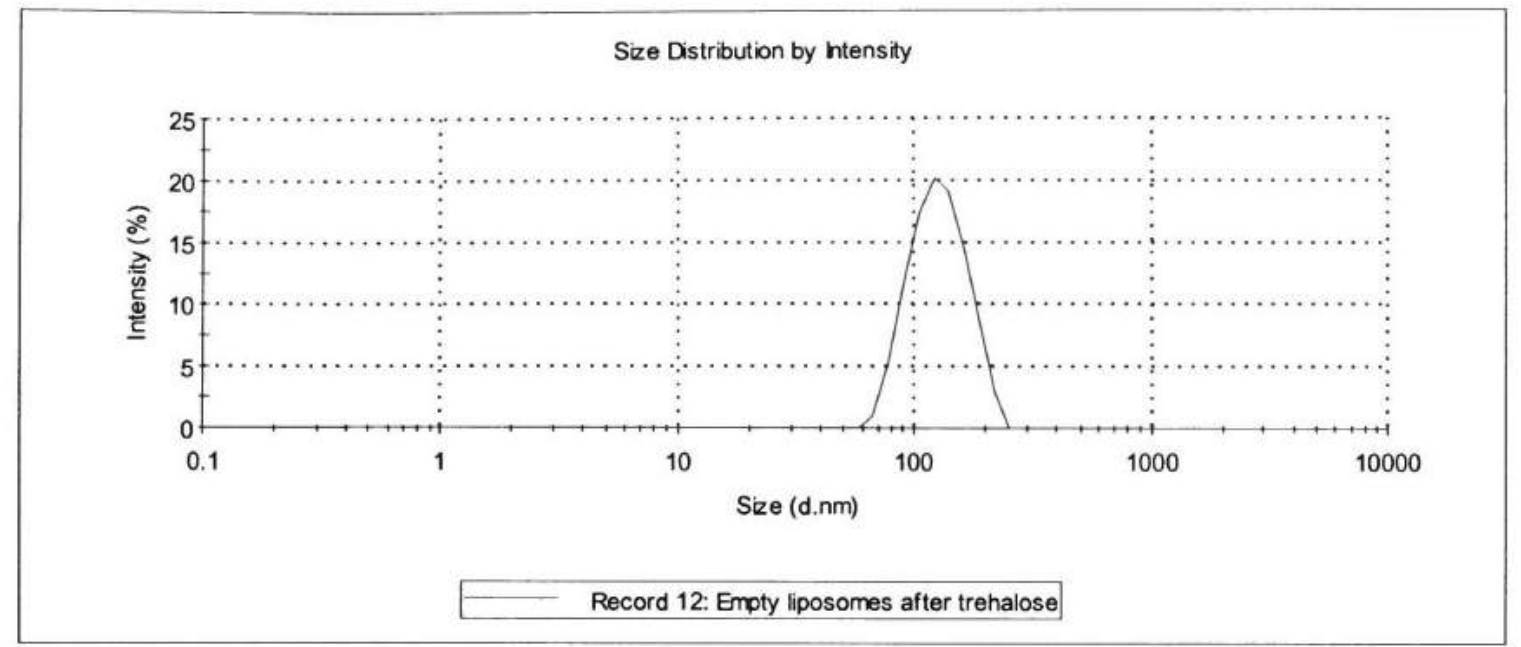

Figure 8. Empty liposomes size distribution curve on the $1^{\text {st }}$ day of storage at $4^{\circ} \mathrm{C}$. Obtained in the Malvern Zetasizer for liposomes after extrusion and trehalose addition. The polydispersity index corresponding to this curve is 0.059 and the average $Z$ size is $123 \mathrm{~nm}$.

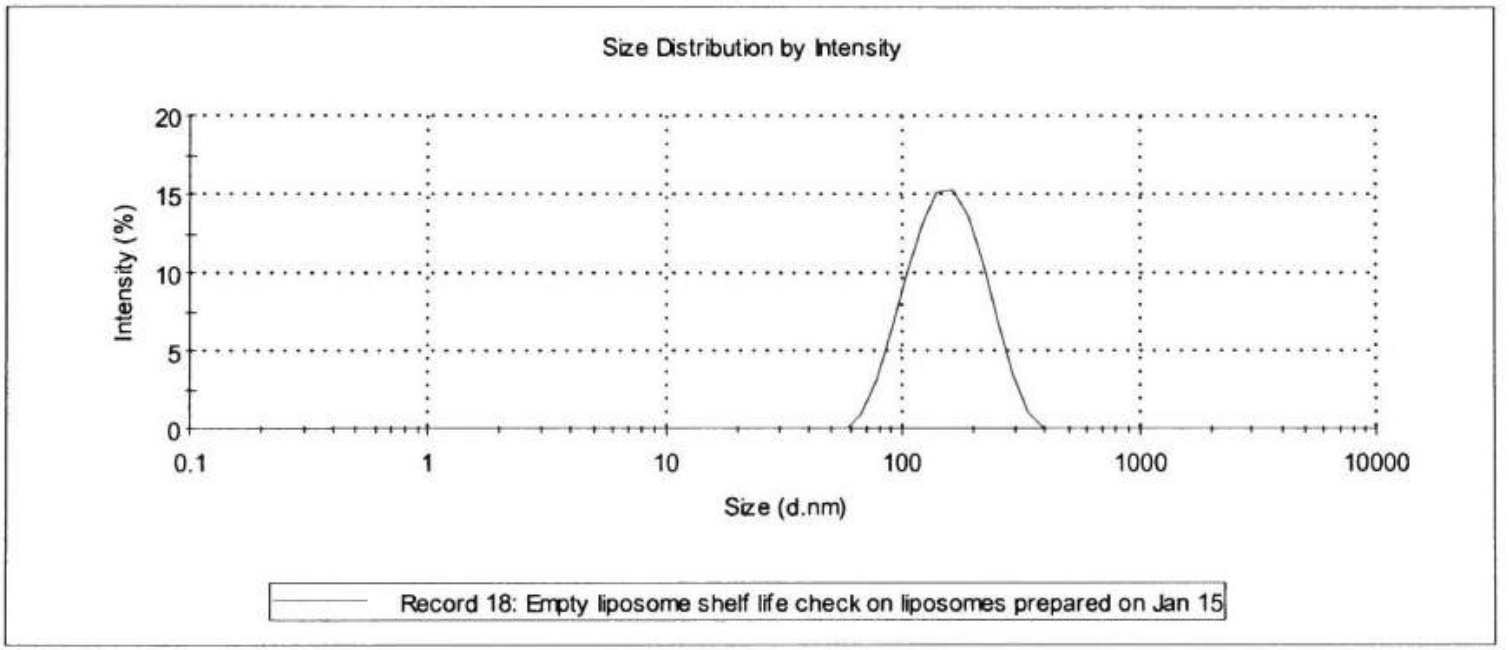

Figure 9. Empty liposome size distribution curve after one week of storage at $4^{\circ} \mathrm{C}$. The polydispersity index corresponding to this curve is 0.122 and the average $Z$ size is $143 \mathrm{~nm}$. 
Sze Distribution by ntensity

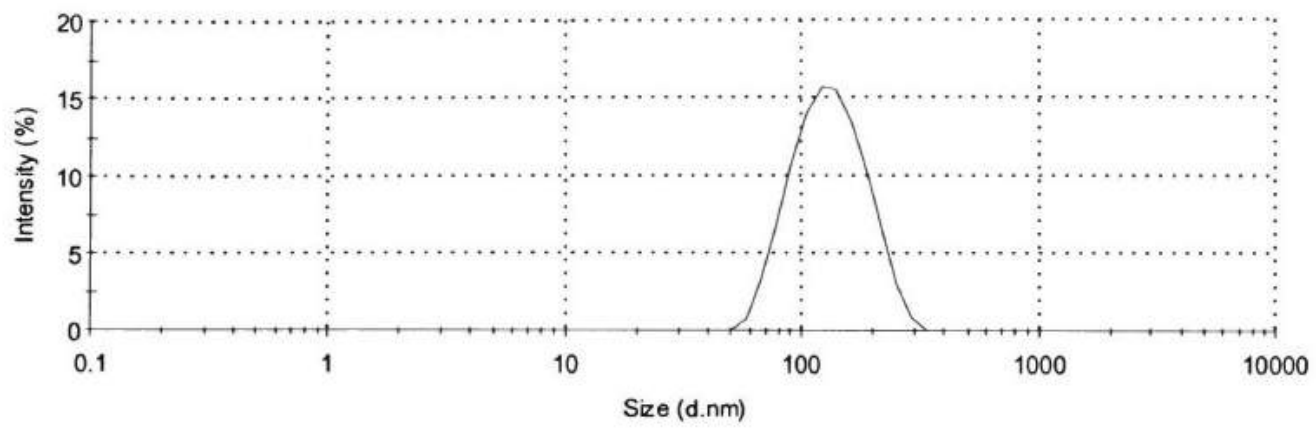

Record 21: MgOC2 liposomes made on January 152008 shelf life Check

Figure 10. Empty liposome size distribution curve after 10 days of storage at $4^{\circ} \mathrm{C}$. The polydispersity index corresponding to this curve is 0.123 and the average $\mathrm{Z}$ size is $122 \mathrm{~nm}$.

Size Distribution by htensity

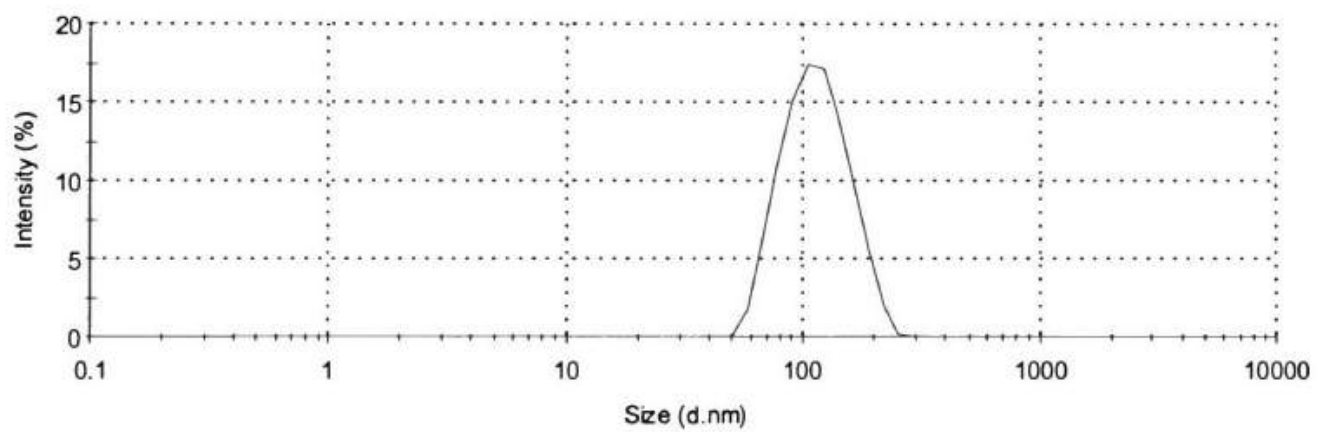

Record 13: MgOCI2 liposomes $20 \%$ trehalose

Figure 11. $\mathrm{MgOCl}_{2}$ liposome on the $1^{\text {st }}$ day of storage at $4^{\circ} \mathrm{C}$. Extruded liposome batch with the addition of trehalose. The polydispersity index corresponding to this curve is 0.093 and the average $\mathrm{Z}$ size is $108 \mathrm{~nm}$. 


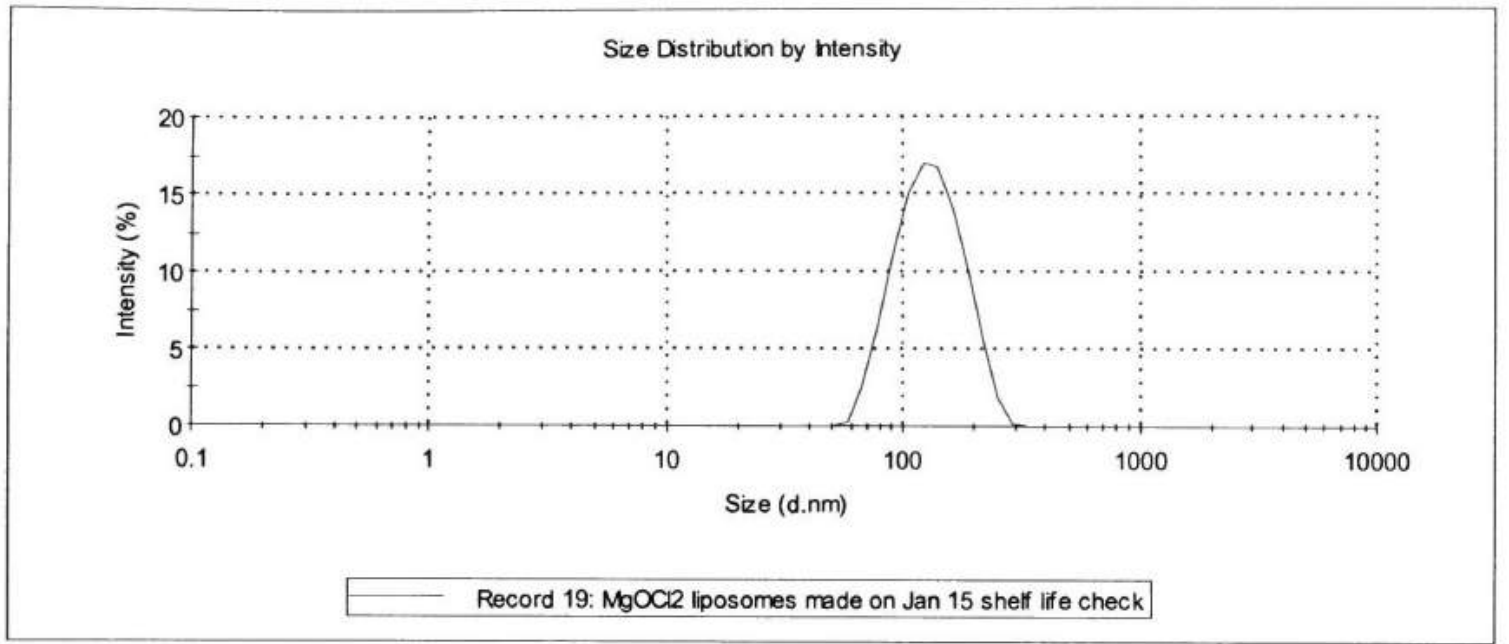

Figure 12. $\mathrm{MgOCl}_{2}$ liposomes, stored at $4^{\circ} \mathrm{C}$ for one week. The polydispersity index corresponding to this curve is 0.101 and the average $Z$ size is $122 \mathrm{~nm}$.

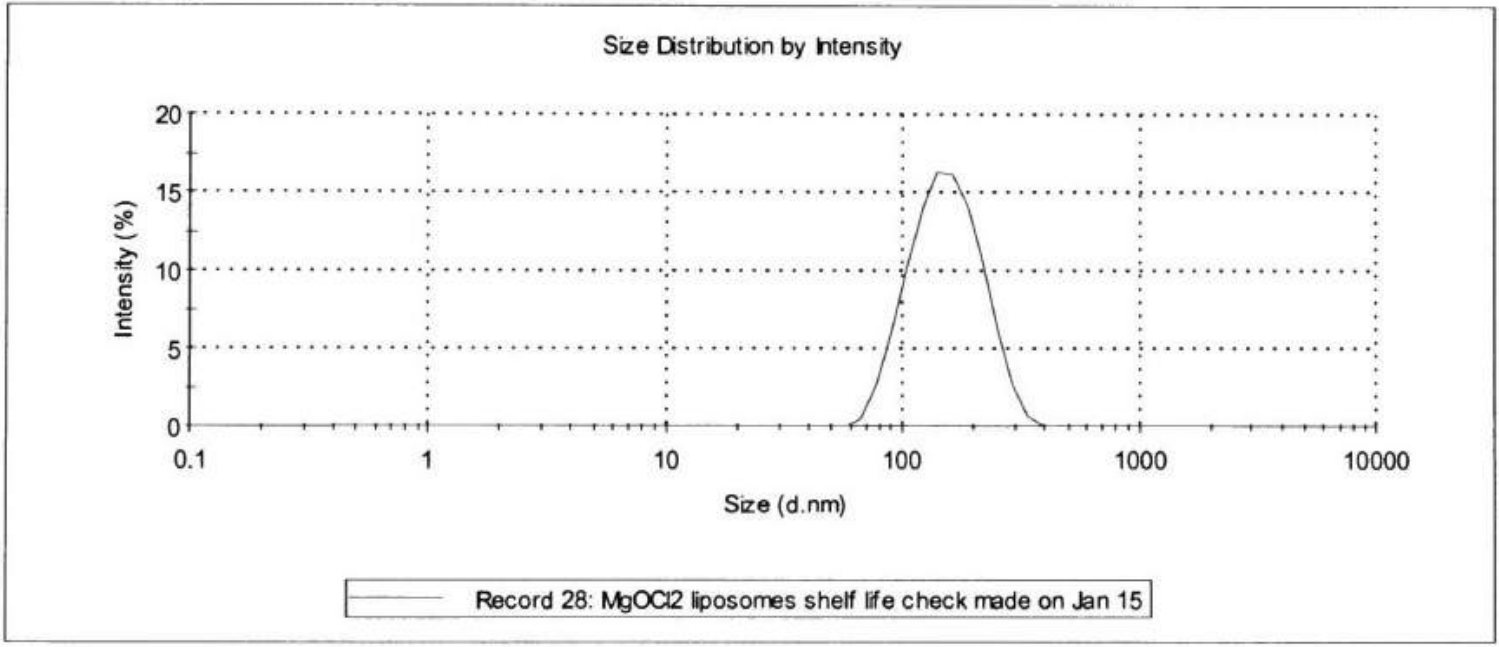

Figure 13. $\mathrm{MgOCl}_{2}$ liposomes, stored at $4^{\circ} \mathrm{C}$ for 3 weeks. The polydispersity index corresponding to this curve is 0.122 and the average $Z$ size is $146 \mathrm{~nm}$. 


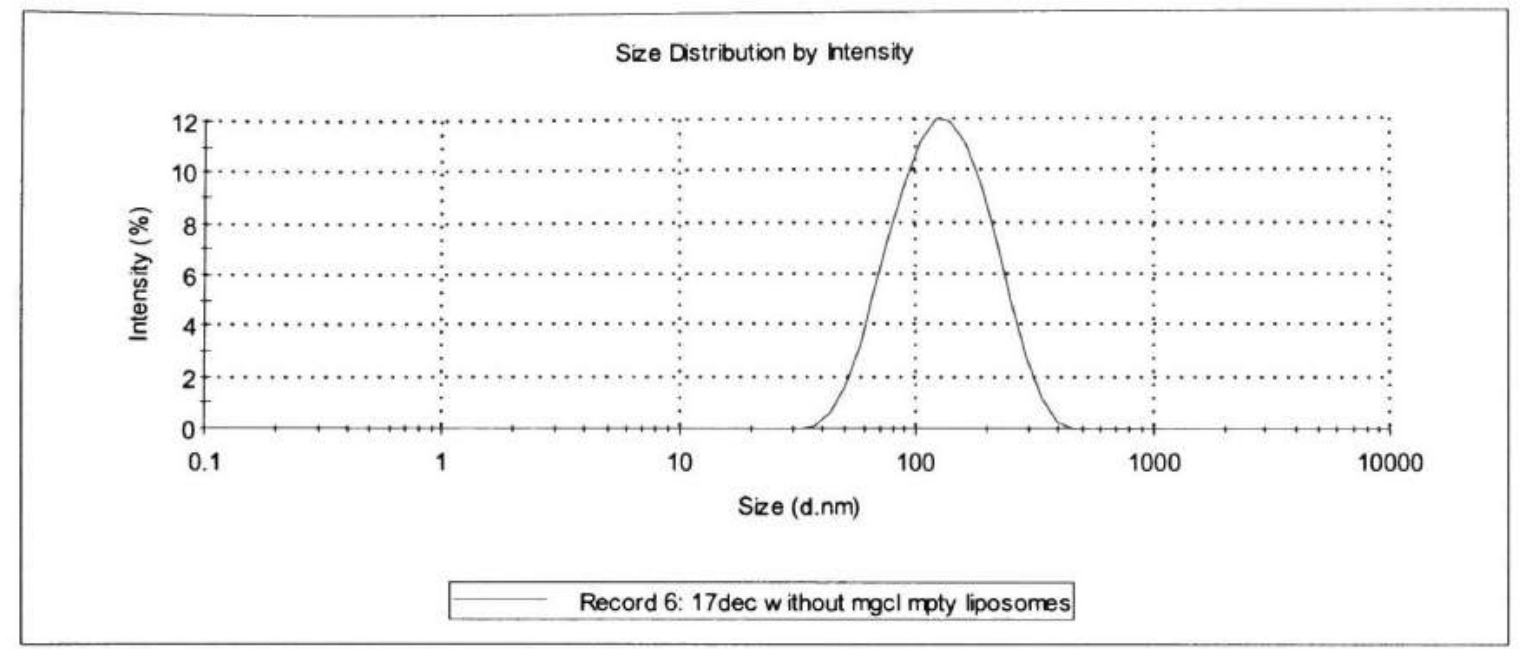

Figure 14. Empty liposomes batch 2, on the $1^{\text {st }}$ day of storage at $4^{\circ} \mathrm{C}$. Size Distribution curve obtained in the Malvern Zetasizer for liposomes after extrusion and trehalose addition. The polydispersity index corresponding to this curve is 0.180 and the average $Z$ size is $116 \mathrm{~nm}$.

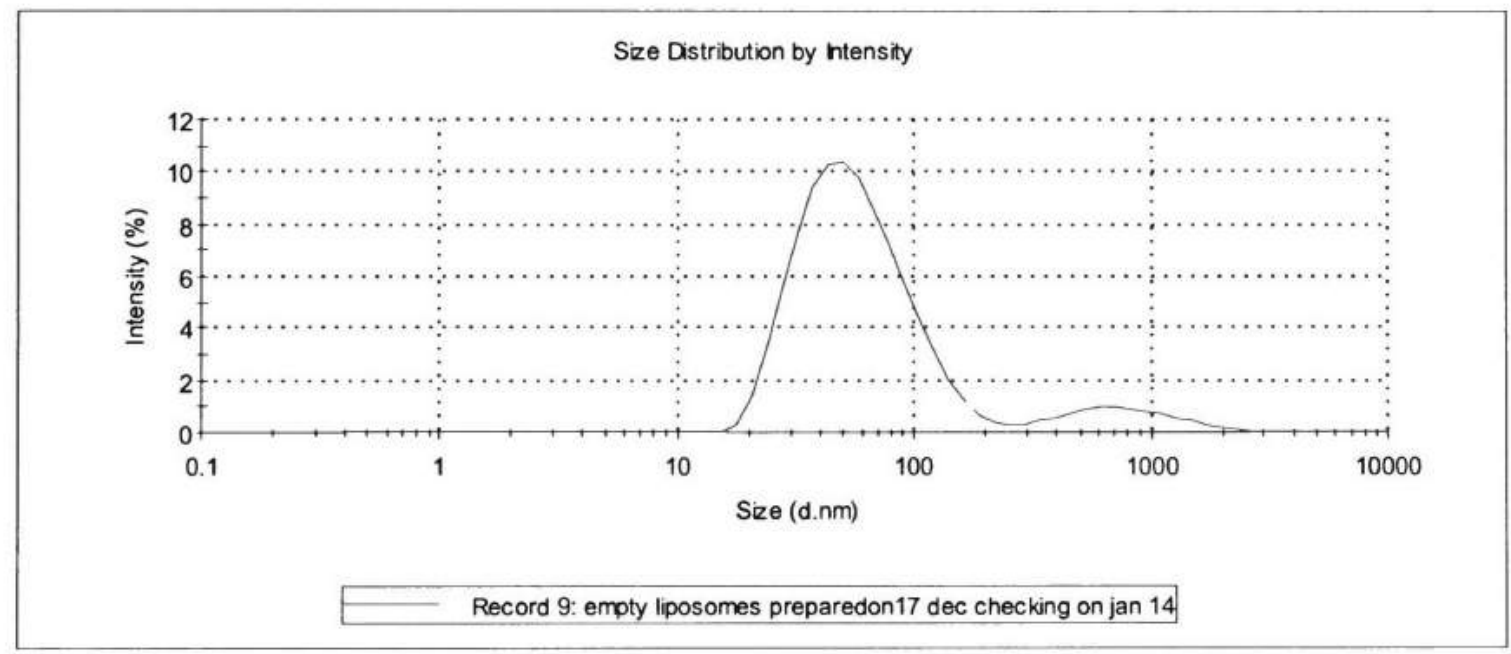

Figure 15. Empty liposomes batch 2, stored at $4^{\circ} \mathrm{C} 4$ weeks. Size Distribution curve obtained in the Malvern Zetasizer for liposomes after storage in $4^{\circ} \mathrm{C}$ for a 4 weeks period. The polydispersity index corresponding to this curve is 0.283 and the average $Z$ size is $50.8 \mathrm{~nm}$. 


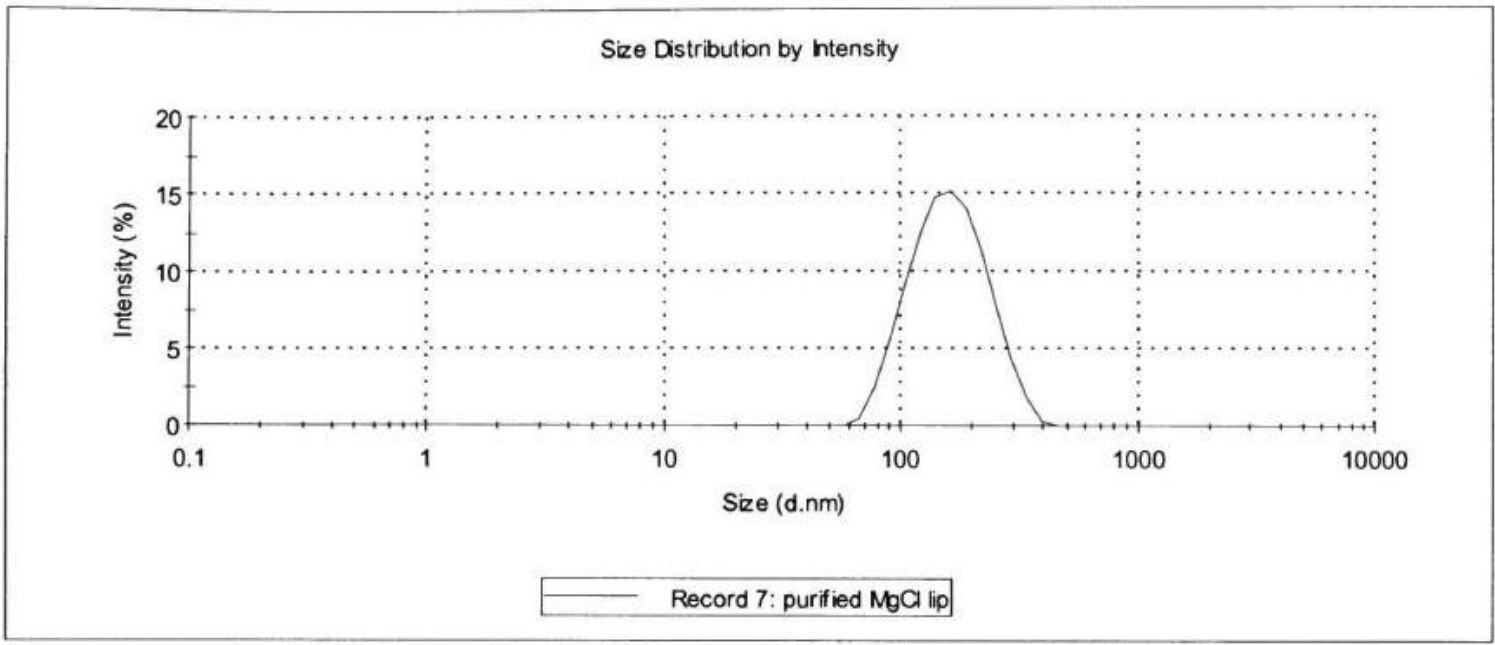

Figure 16. $\mathrm{MgOCl}_{2}$ liposomes batch 2 , on the $1^{\text {st }}$ day of storage at $4^{\circ} \mathrm{C}$. Size Distribution curve obtained in the Malvern Zetasizer for liposomes after extrusion and Trehalose addition, on the $1^{\text {st }}$ day of storage. The polydispersity index corresponding to this curve is 0.299 and the average $Z$ size is $125 \mathrm{~nm}$.

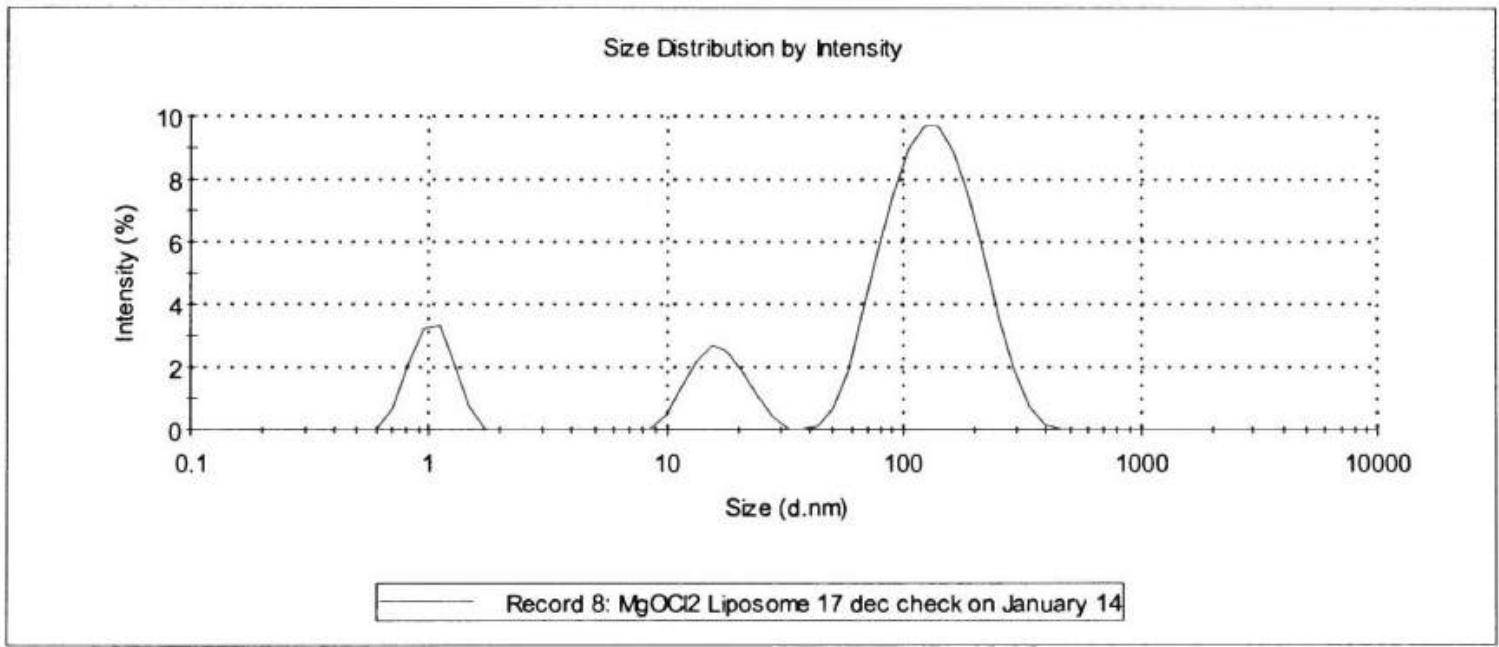

Figure 17. $\mathrm{MgOCl}_{2}$ liposomes batch 2 stored at $4^{\circ} \mathrm{C} 4$ weeks. Size Distribution curve obtained in the Malvern Zetasizer for liposomes after 4 weeks of storage. The polydispersity index corresponding to this curve is 0.653 and the average $Z$ size is $61.4 \mathrm{~nm}$. 


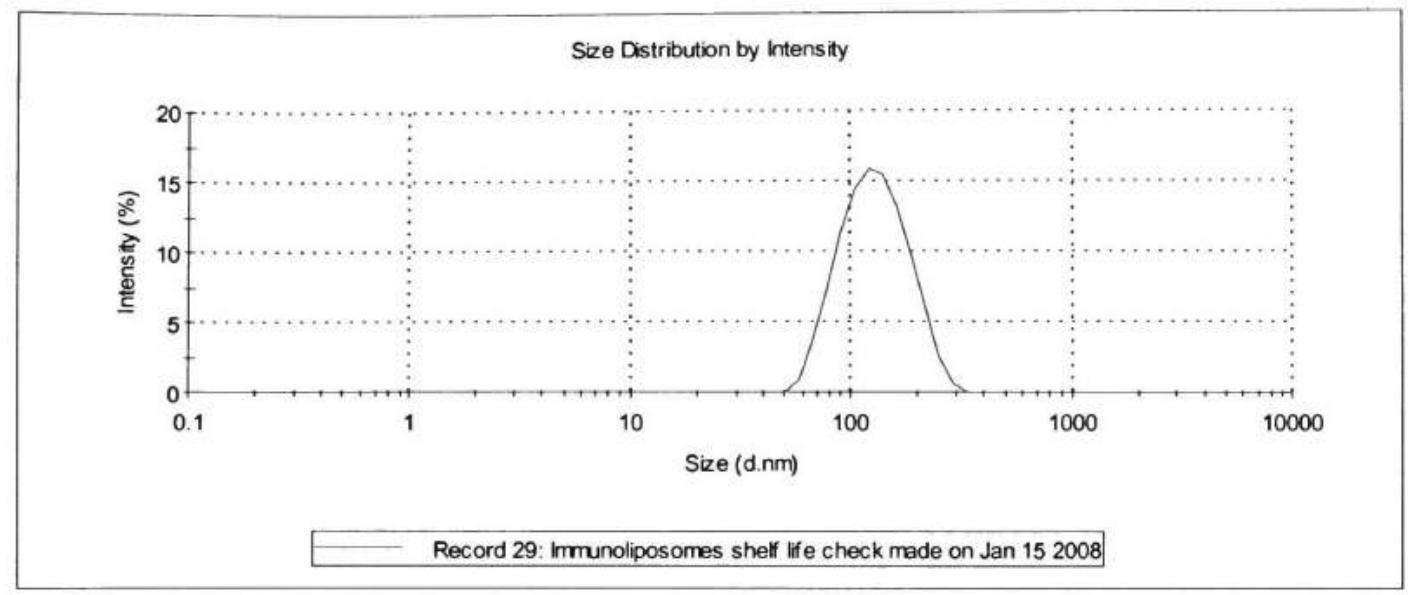

Figure 18. $\mathrm{MgOCl}_{2}$ immunoliposomes $1^{\text {st }}$ day of storage at $4^{\circ} \mathrm{C}$. Size Distribution curve obtained in the Malvern Zetasizer for liposomes where the polydispersity index corresponding to this curve is 0.299 and the average $Z$ size is $120 \mathrm{~nm}$.

\section{Size Distribution by intensity}

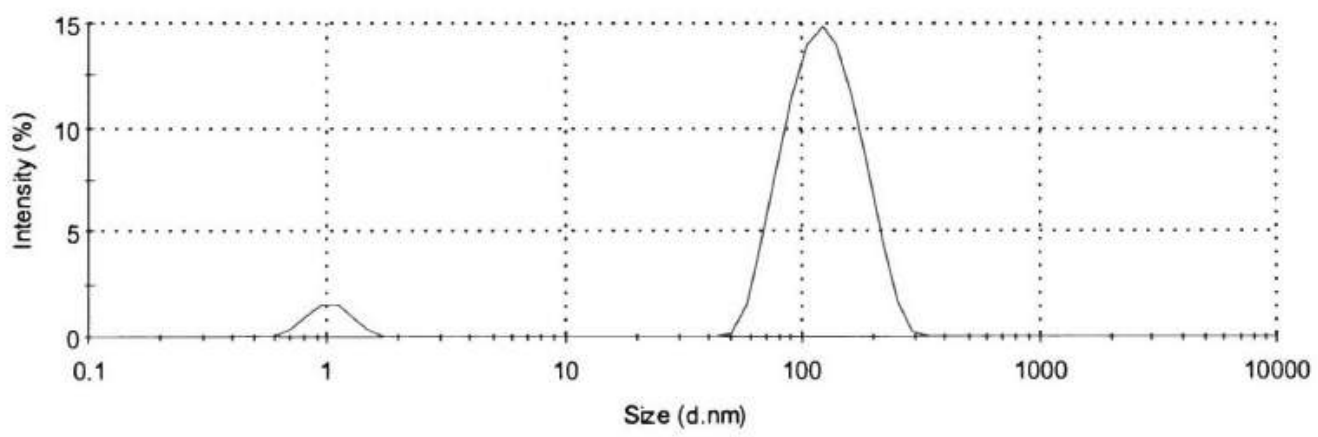

Record 20: immunoliposomes made on Jan 15 shelf life check

Figure 19. $\mathrm{MgOCl}_{2}$ immunoliposomes stored 10 days at $4^{\circ} \mathrm{C}$. Size Distribution curve obtained in the Malvern Zetasizer for liposomes after 10 days of storage. The polydispersity index corresponding to this curve is 0.235 and the average $Z$ size is $103 \mathrm{~nm}$. 


\subsection{BCA Assay}

The BCA assay standard curve was used to approximate the amount of total protein (Streptavidin plus Anti-Bacillus antibody) present after the crosslinking and purification of the Streptavidn-Antibody complex. The average absorbance for the protein solutions after subtracting the average $595 \mathrm{~nm}$ absorbance measurement of the blank standard was 0.048. From this value an interpolation in the BCA standard curve was done to obtain a $44.2 \mu \mathrm{g} / \mathrm{ml}$ concentration for the Streptavidin-Antibody complex.

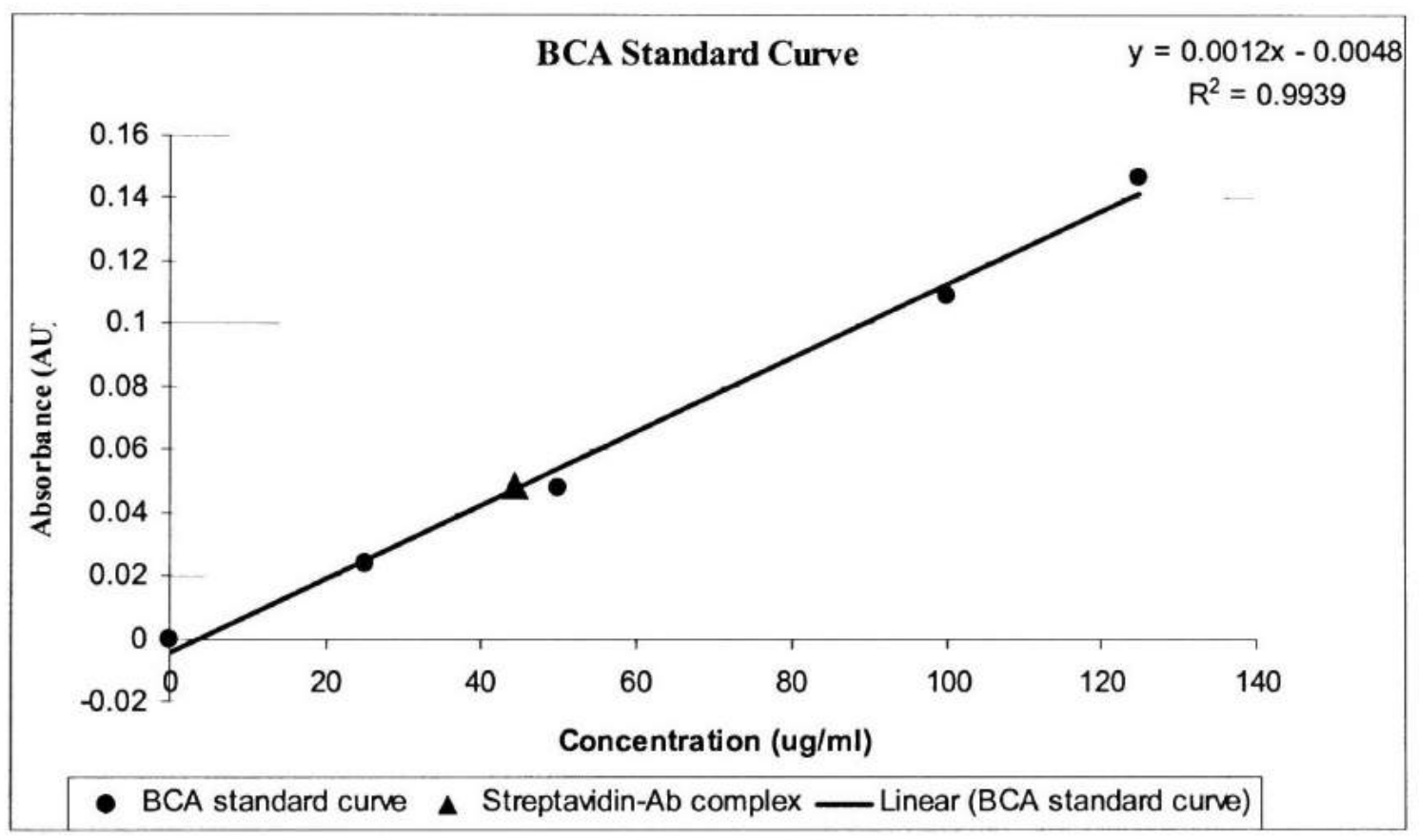

Figure 20. BCA standard curve. The Streptavidin-antibody absorbance and concentration point is represented with the black triangle $(44.2 \mu \mathrm{g} / \mathrm{ml}, 0.0482)$. 


\subsection{Minimum Inhibitory Concentration (MIC) assay}

B. thuringiensis with a theoretical concentration of $1 \times 10^{5}$ cells/ $\mathrm{ml}$ was incubated for a period of 22 hours with different $\mathrm{MgOCl}_{2}$ solution concentrations $2 \mathrm{M} ; 1 \mathrm{M} ; 0.5 \mathrm{M}$; $30 \mathrm{mM} ; 3 \mathrm{mM} ; 1.5 \mathrm{mM} ; 0.75 \mathrm{mM} ; 0.3 \mathrm{mM} ; 0.15 \mathrm{mM} ; 0.075 \mathrm{mM}$; and $\mathrm{MgOCl}_{2}$ liposomes. Samples of $100 \mu 1$ were plated in different Petri dishes at time 0 and after 22 hours of incubation, the bacterial growth was observed. The plates containing high $\mathrm{MgOCl}_{2}$ concentrations (2 $\mathrm{M}, 1 \mathrm{M}$ and $0.5 \mathrm{M}$ ) showed no bacterial growth. Bacterial growth was observed in the plates that contained the drug concentrations from $30 \mathrm{mM}$ to $0.075 \mathrm{mM}$ plates $\mathrm{A} 6, \mathrm{~B} 6, \mathrm{C} 6, \mathrm{~A}, \mathrm{~F}, \mathrm{E}, \mathrm{G}$, and $\mathrm{H}$ (Figure 19). The plate containing the $\mathrm{MgOCl}_{2}$ liposomes incubated with the bacteria (D6) had no bacterial growth, indicative of the efficiency provided by the liposomes.

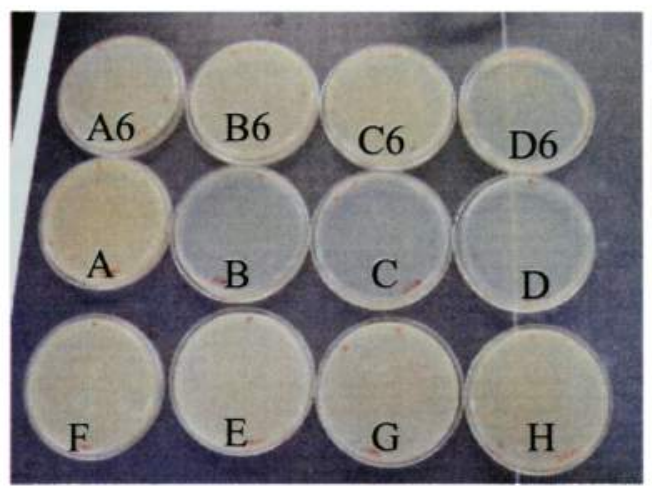

Figure 21. MIC for B. thuringiensis after 22 hours of incubation. Observe plates A6, B6, C6, A, F, E, E, G, H bacterial growth. In plates B, C, D, and D6 you can see through the plate, and no bacterial growth was observed. See table 2 for plate identification.

\subsection{Colony Growth Assay (CGA)}

A CGA for B. thuringiensis was performed as a quantification method for the bactericidal effect of the $\mathrm{MgOCl}_{2}$ liposomes, and the $\mathrm{MgOCl}_{2}$ immunoliposomes. A two 
sample paired t-test for means was used to compare the reduction effect caused by HEPES buffer; empty liposomes; and $3 \mathrm{mM} \mathrm{MgOCl}_{2}$ to the $\mathrm{MgOCl}_{2}$ liposomes and $\mathrm{MgOCl}_{2}$-immunoliposomes effect.

\begin{tabular}{|c|c|c|c|c|c|c|}
\hline & Test 1 & Test 2 & Test 3 & Test 4 & Avg & Stdev \\
\hline HEPES & & & & & & \\
\hline 1 hour & 0.0 & 0.0 & 0.0 & 0.0 & 0.0 & 0.0 \\
\hline 2 hours & 0.0 & 0.0 & 0.0 & 0.0 & 0.0 & 0.0 \\
\hline Empty liposomes & & & & & & \\
\hline 1 hour & 36.2 & 30.3 & 78.0 & 31.9 & $44.1^{*}$ & 22.7 \\
\hline 2 hours & 100.0 & 0.0 & 0.0 & 100.0 & 50.0 & 57.7 \\
\hline $\begin{array}{c}\text { MgOCl } \\
\text { liposomes }\end{array}$ & & & & & & \\
\hline 1 hour & 57.8 & 55.1 & 80.0 & 38.0 & $57.7^{*+}$ & 17.2 \\
\hline 2 hours & 26.5 & 60.3 & 40.0 & 33.8 & $40.2^{*}$ & 14.5 \\
\hline $\begin{array}{c}\text { MgOCl } \\
\text { immunoliposomes }\end{array}$ & & & & & & \\
\hline 1 hour & 0.0 & 20.8 & 52.3 & 0.0 & 18.3 & 24.7 \\
\hline 2 hours & 0.0 & 57.7 & 38.3 & 0.0 & 24.0 & 28.8 \\
\hline 3mM MgOCl & & & & & & \\
\hline 1 hour & 0.0 & 0.0 & 32.0 & 0.0 & $8.0^{+}$ & 16.0 \\
\hline 2 hours & 0.0 & 41.7 & 34.8 & 0.0 & 19.1 & 22.3 \\
\hline
\end{tabular}

Table 4-1. Reduction percentages of four different tests for $B$. thuringiensis CGA, where * means p value $<$ than 0.05 compared to Hepes and + means $p$ value $<0.05$ compared to empty liposomes. 


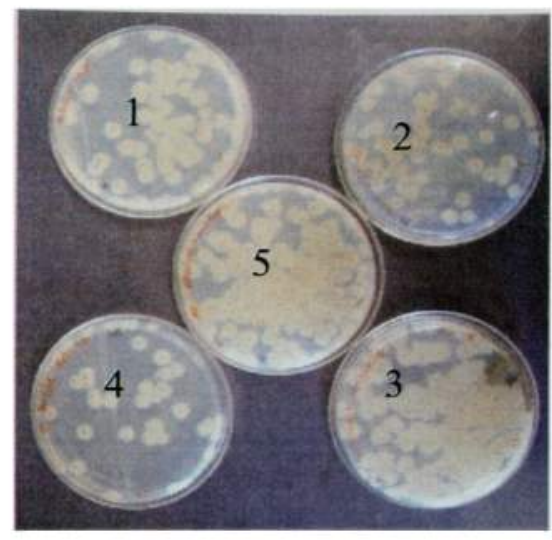

(A)

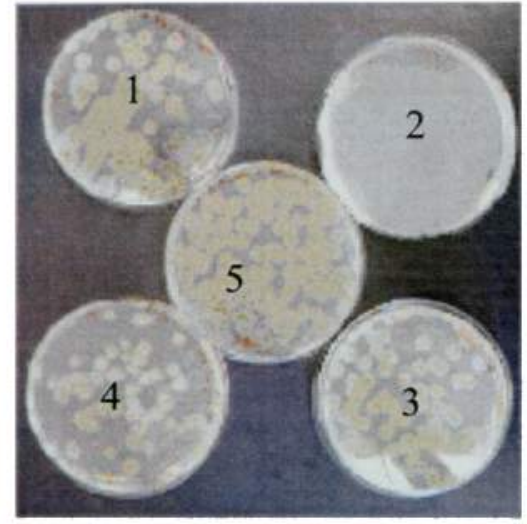

(B)

Figure 22. Colony growth assay (CGA) for test \#1 (A) CGA for B. thuringiensis after 1 hour (B) CGA for $B$. thuringiensis after 2 hours of treatment with $\mathbf{M g O C l}_{2}$ solutions, incubated overnight. Where 1, is B. thuringiensis in HEPES, 2, is B. thuringiensis in Empty liposomes, 3, B. thuringiensis in $\mathrm{MgOCl}_{2}$ immunoliposomes, 4 , is $B$. thuringiensis in $\mathrm{MgOCl}_{2}$ liposomes, and 5 , is $\mathrm{B}$. thuringiensis in $3 \mathrm{mM} \mathrm{MgOCl} 2$ solution.

CGA $p$ values from the $t$ :Test after 1 hour of treatment with bacteria

\begin{tabular}{|c|c|c|}
\hline & $\begin{array}{c}\text { B. thuringiensis } \\
\text { P value compared to HEPES } \\
\text { buffer }\end{array}$ & $\begin{array}{c}\text { B. thuringiensis } \\
\text { P value compared to Empty } \\
\text { liposomes }\end{array}$ \\
\hline HEPES & N/A & 0.015 \\
\hline Empty liposomes & 0.015 & N/A \\
\hline $\mathrm{MgOCl}_{2}$ lip & 0.034 & 0.47 \\
\hline Immunoliposomes & 0.12 & 0.010 \\
\hline $3 \mathrm{mM} \mathrm{MgOCl}_{2}$ & 0.20 & 0.00099 \\
\hline
\end{tabular}

Table 4-2. B. thuringiensis CGA $P$ values from a t-Test comparing the effect of $\mathbf{M g O C l}_{2}$ liposomes, $3 \mathrm{mM} \mathrm{MgOCl}$ and $\mathrm{MgOCl}_{2}$-immunoliposomes vs. the control HEPES and empty liposomes at 1 hour of bacteria treatment. 
CGA $p$ values from the t:Test after 2 hours of treatment with bacteria

\begin{tabular}{|c|c|c|}
\hline & $\begin{array}{c}\text { B. thuringiensis } \\
\text { P value compared to HEPES } \\
\text { buffer }\end{array}$ & $\begin{array}{c}\text { B. thuringiensis } \\
\text { P value compared to Empty } \\
\text { liposomes }\end{array}$ \\
\hline HEPES & N/A & 0.090 \\
\hline Empty liposomes & 0.090 & N/A \\
\hline $\mathrm{MgOCl}_{2}$ lip & 0.0057 & 0.40 \\
\hline Immunoliposomes & 0.097 & 0.29 \\
\hline $3 \mathrm{mM} \mathrm{MgOCl}_{2}$ & 0.092 & 0.25 \\
\hline
\end{tabular}

Table 4-3. B. thuringiensis colony growth assay (CGA) $P$ values from a t-Test comparing the effect of $\mathrm{MgOCl}_{2}$ liposomes, $3 \mathrm{mM} \mathrm{MgOCl}$ and $\mathrm{MgOCl}_{2}$-immunoliposomes vs. the controls $\mathrm{HEPES}$ and empty liposomes at 2 hours of bacteria treatment.

CGA p values from the t:Test, comparison of the general effect of liposomes vs. the controls

\begin{tabular}{|c|c|c|}
\hline & $\begin{array}{c}\text { B. thuringiensis } \\
\text { P value compared to HEPES } \\
\text { buffer }\end{array}$ & $\begin{array}{c}\text { B. thuringiensis } \\
\text { P value compared to Empty } \\
\text { liposomes }\end{array}$ \\
\hline HEPES & N/A & 0.0272 \\
\hline Empty liposomes & 0.00687 & N/A \\
\hline $\mathrm{MgOCl}_{2}$ lip & $4.87 \mathrm{E}-05$ & 0.0178 \\
\hline Immunoliposomes $_{3 \mathrm{mgOCl}}$ & 0.0242 & 0.457 \\
\hline $3 \mathrm{mM} \mathrm{MgOCl}$ & 0.0410 & 0.253 \\
\hline
\end{tabular}

Table 4-4. B. thuringiensis colony growth assay (CGA) $P$ values from a t-Test comparing the general effect (combining 1 and 2 hours) of $\mathrm{MgOCl}_{2}$ liposomes, $3 \mathrm{mM} \mathrm{MgOCl}$ and $\mathrm{MgOCl}_{2}$ immunoliposomes vs. the controls HEPES and empty liposomes.

\subsection{Live/Dead Assay}

The bacterium B. thuringiensis, B. subtilis and B. cereus were incubated with 5 different solutions; HEPES buffer; empty liposomes; $\mathrm{MgOCl}_{2}$ liposomes; $\mathrm{MgOCl}_{2}$ immunoliposomes; and $3 \mathrm{mM} \mathrm{MgOCl}_{2}$. The vials containing the different solutions were centrifuged in a Pico Fuge microcentrifuge at 10,000 RPM for 10 minutes. The supernatant was removed and $1 \mathrm{ml}$ of HEPES, Empty liposomes, $\mathrm{MgOCl}_{2}$ liposomes, $\mathrm{MgOCl}_{2}$ immunoliposomes, or $3 \mathrm{mM} \mathrm{MgOCl}_{2}$ solutions were re-suspended in each vial. 
Three (3) samples of $150 \mu 1$ of the re-suspended solution were placed in a 96-well plate and $0.15 \mu 1$ of the mixed fluorescent dyes was added to the solutions. The 96-well plate was incubated for 15 minutes. Three microscope slides were prepared with $5 \mu 1$ of the dyed solution and observed at $40 \mathrm{X}$ under the fluorescent microscope. A total count of 100 live and dead cells was performed and pictures were captured. Reduction percentages at time 0 hours and 1 hour are shown on tables $7,8,10,11,13$, and 14 . In order to determine the statistical significance of the reduction percentages obtained, a two sample paired t-test for means was performed The t:test compared the reduction percentages of the bacteria incubated with the controls, HEPES, and empty liposomes, at time 1 hour versus the reduction effect of the liposomes and free drug at 1 hour of incubation. The tables presenting the p-values for B. thuringiensis, B. cereus and B. subtilis are 9,12 , and 15 respectively.

\subsubsection{Bacillus thuringiensis live/dead assay results}

Average reduction times of $B$. thuringiensis at 0 hour of incubation with the solutions

\begin{tabular}{|c|c|c|c|c|c|}
\hline & $\begin{array}{c}\text { Avg. } \\
\text { Reduction } \\
\text { \% HEPES }\end{array}$ & $\begin{array}{c}\text { Avg. } \\
\text { Reduction } \\
\text { \% Empty } \\
\text { Liposomes }\end{array}$ & $\begin{array}{c}\text { Avg. } \\
\text { Reduction } \\
\text { \% MgOCl } \\
\text { liposomes }\end{array}$ & $\begin{array}{c}\text { Avg. Reduction } \\
\text { \% } \mathbf{~ M g O C l}_{\mathbf{2}} \\
\text { immuno- } \\
\text { liposomes }\end{array}$ & $\begin{array}{c}\text { Avg. } \\
\text { Reduction } \\
\text { \% 3mM } \\
\mathbf{M g O C l}_{\mathbf{2}}\end{array}$ \\
\hline Test 1 & 12.3 & 4.3 & 15.0 & 15.0 & 7.7 \\
\hline Test 2 & 14.0 & 20.7 & 37.0 & 26.0 & 11.3 \\
\hline Test 3 & 28.0 & 19.0 & 12.5 & 18.9 & 19.5 \\
\hline Avg & 18.1 & 14.7 & 21.5 & 20.0 & 12.8 \\
\hline Stdev & 8.6 & 9.0 & 13.5 & 5.6 & 6.0 \\
\hline
\end{tabular}

Table 4-5. B. thuringiensis, live/dead assay reduction percentages averages at time 0 hr. At this time non significant reduction percentages were observed in the t:test performed. 
Average reduction times of $B$. thuringiensis at 1 hour of incubation with the solutions

\begin{tabular}{|c|c|c|c|c|c|}
\hline & $\begin{array}{c}\text { Avg. } \\
\text { Reduction } \\
\text { \% HEPES }\end{array}$ & $\begin{array}{c}\text { Avg. } \\
\text { Reduction } \\
\text { \% Empty } \\
\text { liposomes }\end{array}$ & $\begin{array}{c}\text { Avg. } \\
\text { Reduction } \\
\text { \% } \mathbf{M g O C l}_{\mathbf{2}} \\
\text { liposomes }\end{array}$ & $\begin{array}{c}\text { Avg. Reduction } \\
\text { \% } \mathbf{M g O C l}_{\mathbf{2}} \\
\text { immuno- } \\
\text { liposomes }\end{array}$ & $\begin{array}{c}\text { Avg. } \\
\text { Reduction } \\
\text { \% 3mM } \\
\mathbf{M g O C l}_{\mathbf{2}}\end{array}$ \\
\hline Test 1 & 8.7 & 7.7 & 20.0 & 22.0 & 13.0 \\
\hline Test 2 & 10.7 & 18.7 & 32.0 & 27.0 & 30.0 \\
\hline Test 3 & 25.3 & 31.1 & 43.0 & 40.0 & 36.0 \\
\hline Avg & 14.9 & 19.2 & $31.7^{+}$ & $29.7^{+}$ & $26.3^{+}$ \\
\hline Stdev & 9.1 & 11.7 & 11.5 & 9.3 & 11.9 \\
\hline
\end{tabular}

Table 4-6. $B$. thuringiensis, live/dead assay average bacterial reduction percentages at time $1 \mathrm{hr}$, where * means $p$ value $<$ than 0.05 compared to HEPES and + means p value $<0.05$ compared to Empty liposomes

B. thuringiensis live/dead assay $\mathrm{p}$ values from the t:Test samples for means at time 1 hour

\begin{tabular}{|l|c|c|}
\hline & $\begin{array}{c}\text { B. thuringiensis } \\
\text { P value compared to } \\
\text { HEPES buffer }\end{array}$ & $\begin{array}{c}\text { B. thuringiensis } \\
\text { P value compared to } \\
\text { Empty liposomes }\end{array}$ \\
\hline $\mathrm{HEPES}$ & N/A & 0.128 \\
\hline Empty liposomes & 0.128 & $\mathrm{~N} / \mathrm{A}$ \\
\hline $\mathrm{MgOCl}_{2}$ liposomes & 0.0145 & 0.000554 \\
\hline $\mathrm{MgOCl}_{2}$-Immunoliposomes & 0.0071 & 0.0157 \\
\hline $3 \mathrm{mM} \mathrm{MgOCl}_{2}$ & 0.0560 & 0.0371 \\
\hline
\end{tabular}

Table 4-7. B. thuringiensis, $P$ values from a t-test: for means. The reduction percentage caused by the controls (HEPES and empty liposomes) were compared to the effect of the $\mathrm{MgOCl}_{2}$ liposomes, $\mathbf{M g O C l}_{2}$-immunoliposomes and $3 \mathrm{mM} \mathbf{M g O C l}_{2}$ after one hour of incubation.

Significant reduction percentages were observed for the $\mathrm{MgOCl}_{2}$ liposomes; $\mathrm{MgOCl}_{2}$-immunoliposomes, and $3 \mathrm{mM} \mathrm{MgOCl}_{2}$. The highest reduction percentage was observed in the $\mathrm{MgOCl}_{2}$ liposomes $31.7 \%$, compared to a $26.0 \%$ reduction caused by the free drug and a reduction of $29.0 \%$ was observed for the $\mathrm{MgOCl}_{2}$-immunoliposomes. 


\subsubsection{Bacillus cereus, live/dead assay results}

Average reduction times of $B$. cereus at 0 hours of incubation with the solutions

\begin{tabular}{|c|c|c|c|c|}
\hline & $\begin{array}{c}\text { Avg. } \\
\text { Reduction } \\
\text { \% HEPES }\end{array}$ & $\begin{array}{c}\text { Avg. } \\
\text { Reduction } \\
\text { \% Empty } \\
\text { Liposomes }\end{array}$ & $\begin{array}{c}\text { Avg. } \\
\text { Reduction } \\
\text { \% } \mathbf{~ M g O C l}_{\mathbf{2}} \\
\text { liposomes }\end{array}$ & $\begin{array}{c}\text { Avg. Reduction } \\
\text { \% } \mathbf{~ M g O C l}_{\mathbf{2}} \\
\text { immuno- } \\
\text { liposomes }\end{array}$ \\
\hline Test 1 & 14.14 & 14.7 & 13.0 & 10.0 \\
\hline Test 2 & 30.56 & 10.9 & 20.5 & 13.0 \\
\hline Test 3 & 26.0 & 10.6 & 20.2 & 21.6 \\
\hline Avg & 23.6 & 12.1 & 17.9 & 17.3 \\
\hline Stdev & 8.5 & 2.3 & 4.2 & 6.0 \\
\hline
\end{tabular}

Table 4-8. B cereus, percentage reduction averages using different solutions at time $0 \mathrm{hr}$ for the live dead assay.

Average reduction times of $B$. cereus at 1 hour of incubation with the solutions

\begin{tabular}{|c|c|c|c|c|}
\hline & $\begin{array}{c}\text { Avg. } \\
\text { Reduction \% } \\
\text { HEPES }\end{array}$ & $\begin{array}{c}\text { Avg. } \\
\text { Reduction \% } \\
\text { Empty } \\
\text { Liposomes }\end{array}$ & $\begin{array}{c}\text { Avg. } \\
\text { Reduction \% } \\
\text { MgOCl } \\
\text { liposomes }\end{array}$ & $\begin{array}{c}\text { Avg. Reduction \% } \\
\mathbf{M g O C l}_{2} \text { immuno- } \\
\text { liposomes }\end{array}$ \\
\hline Test 1 & 32.2 & 26.0 & 34.6 & 38.0 \\
\hline Test 2 & 28.5 & 34.0 & 27.7 & 32.7 \\
\hline Test 3 & 31.0 & 32.0 & 29.0 & 20.0 \\
\hline Avg & 30.5 & 30.7 & 30.4 & 30.2 \\
\hline Stdev & 1.9 & 4.2 & 3.7 & 9.3 \\
\hline
\end{tabular}

Table 4-9. B cereus, percentage reduction averages using different solutions at time $1 \mathrm{hr}$ for the live dead assay. 
B. cereus live dead $\mathrm{p}$ values from the t:Test paired two samples for means

\begin{tabular}{|l|c|c|}
\hline & $\begin{array}{c}\text { B. cereus } \\
\text { P value compared to } \\
\text { HEPES buffer }\end{array}$ & $\begin{array}{c}\text { B. cereus } \\
\text { P value compared to } \\
\text { Empty liposomes }\end{array}$ \\
\hline HEPES & N/A & 0.487 \\
\hline Empty liposomes & 0.487 & N/A \\
\hline MgOCl $_{2}$ liposomes & 0.471 & 0.482 \\
\hline MgOCl $_{2}$-Immunoliposomes & 0.480 & 0.479 \\
\hline
\end{tabular}

Table 4-10. B. cereus, $P$ values from a t-test: for means, comparing the significance of the effect on the 2 controls HEPES and Empty liposomes vs. the $\mathrm{MgOCl}_{2}$ liposomes and $\mathrm{MgOCl}_{2}$ immunoliposomes. The reduction percentage caused by the controls HEPES and empty liposomes at time $1 \mathrm{hr}$ was compared with its reduction percentage after 1 hour of incubation to the effect of the $\mathrm{MgOCl}_{2}$ liposomes and $\mathrm{MgOCl}_{2}$-immunoliposomes one hour of incubation.

The reduction percentage of $B$. cereus at time 1 hour in solution with HEPES buffer was compared with the effect of the bacteria in solution with empty liposomes, $\mathrm{MgOCl}_{2}$ - liposomes, and $\mathrm{MgOCl}_{2}$-immunoliposomes. The statistical analysis revealed a non-significant increase in reduction percentage. The same statistical analysis was performed for the comparison of the effect of empty liposomes at time 1 hour with the aforementioned solutions. The statistical analysis result of this assay revealed a non significant bactericidal effect on $B$. cereus caused by the $\mathrm{MgOCl}_{2}$ liposomes and $\mathrm{MgOCl}_{2}$-immunoliposomes. The result for this experiment showed a similar reduction percentages averages $(30.5,30.7,30.4$, and 30.2$)$ for each solution. The reduction percentage observed in the controls can be due to the presence of hydrogen peroxide in the HEPES buffer. 


\subsubsection{Bacillus subtilis live/dead assay results}

Average reduction times of $B$. subtilis at 0 hours of incubation with the solutions

\begin{tabular}{|c|c|c|c|c|}
\hline & $\begin{array}{c}\text { Avg. } \\
\text { Reduction \% } \\
\text { HEPES }\end{array}$ & $\begin{array}{c}\text { Avg. } \\
\text { Reduction \% } \\
\text { Empty } \\
\text { Liposomes }\end{array}$ & $\begin{array}{c}\text { Avg. } \\
\text { Reduction \% } \\
\text { MgOCl }_{2} \\
\text { liposomes }\end{array}$ & $\begin{array}{c}\text { Avg. Reduction \% } \\
\text { MgOCl }_{2} \text { immuno- } \\
\text { liposomes }\end{array}$ \\
\hline Test 1 & 10.0 & 11.9 & 16.0 & 6.0 \\
\hline Test 2 & 24.0 & 13.6 & 7.0 & 6.0 \\
\hline Test 3 & 27.0 & 16.0 & 21.0 & 35.9 \\
\hline Avg & 20.3 & 13.8 & 14.7 & 16.0 \\
\hline Stdev & 9.1 & 2.1 & 7.1 & 17.3 \\
\hline
\end{tabular}

Table 4-11. Bacillus subtilis average reduction bacterial percentage at time $0 \mathrm{hr}$.

Average reduction times of $B$. subtilis at 1 hour of incubation with the solutions

\begin{tabular}{|c|c|c|c|c|}
\hline & $\begin{array}{c}\text { Avg. } \\
\text { Reduction \% } \\
\text { HEPES }\end{array}$ & $\begin{array}{c}\text { Avg. } \\
\text { Reduction \% } \\
\text { Empty } \\
\text { Liposomes }\end{array}$ & $\begin{array}{c}\text { Avg. } \\
\text { Reduction \% } \\
\text { MgOCl } \\
\text { liposomes }\end{array}$ & $\begin{array}{c}\text { Avg. Reduction \% } \\
\mathbf{M g O C l}_{2} \text { immuno- } \\
\text { liposomes }\end{array}$ \\
\hline Test 1 & 20.0 & 28.9 & 38.0 & 37.5 \\
\hline Test 2 & 23.0 & 18.0 & 45.7 & 25.0 \\
\hline Test 3 & 26.0 & 23.0 & 53.0 & 40.8 \\
\hline Avg & 23.0 & 23.3 & $45.6^{*^{+}}$ & $34.4^{+}$ \\
\hline Stdev & 3.0 & 5.5 & 7.5 & 8.3 \\
\hline
\end{tabular}

Table 4-12. Bacillus subtilis average reduction bacterial percentage after $1 \mathrm{hr}$ of incubation with the different solutions, where * means $p$ value $<$ than 0.05 compared to Hepes and + means $p$ value $<$ 0.05 compared to Empty liposomes

The reduction percentages observed at time 0 hours suggests that the HEPES buffer caused the highest reduction percentages, but after the bacteria was incubated for an hour the effect of HEPES on the bacteria remained stable while the effect of the $\mathrm{MgOCl}_{2}$ liposomes and $\mathrm{MgOCl}_{2}$ immunoliposomes significantly increased. This 
suggests that the reduction effect observed at time 0 hours for HEPES is not persistent and will disappear after time.

B. subtilis live dead $\mathrm{p}$ values from the t:Test for 1 hour of incubation with bacteria

\begin{tabular}{|l|l|l|}
\hline & $\begin{array}{l}\text { B. subtilis } \\
\text { P value compared to } \\
\text { HEPES buffer }\end{array}$ & $\begin{array}{l}\text { B. subtilis } \\
\begin{array}{l}\text { E value compared to } \\
\text { Empty liposomes }\end{array}\end{array}$ \\
\hline HEPES Buffer & N/A & 0.476 \\
\hline Empty liposomes & 0.476 & N/A \\
\hline $\mathrm{MgOCl}_{2}$ liposomes & 0.00650 & 0.0390 \\
\hline $\mathrm{MgOCl}_{2}$-Immunoliposomes & 0.0670 & 0.0400 \\
\hline
\end{tabular}

Table 4-13. B. subtilis, $P$ values from a t-test: for means, comparing the significance of the effect on the 2 controls HEPES and empty liposomes vs. the $\mathrm{MgOCl}_{2}$ liposomes and $\mathrm{MgOCl}_{2}$ immunoliposomes. The reduction percentage caused by the controls HEPES and empty liposomes at time $1 \mathrm{hr}$ was compared with its reduction percentage after 1 hour of incubation with the effect of the $\mathrm{MgOCl}_{2}$ liposomes, $\mathrm{MgOCl}_{2}$-immunoliposomes after 1 hour of incubation.

Reduction percentages of Bacillus subtilis at time 0 hours and 1 hour of incubation are presented in table 11 and 12 , respectively. The bacterium B. subtilis incubated one hour with empty liposomes and HEPES buffer did not showed a significant reduction percentage. The bacteria show a significant increase in the reduction percentage of $\mathrm{MgOCl}_{2}$ liposomes compared to both controls. The immunoliposomes reduction was $34.4 \%$. The immunoliposomes showed a significant reduction percentage when it was compared to the empty liposomes reduction percentage. 


\subsection{DISCUSSION}

The $\mathrm{MgOCl}_{2}$-liposomes and empty liposomes developed for this thesis preserved its size stability for a period of 15 days, stored at $4^{\circ} \mathrm{C}$. In figure 8 , the empty liposomes size distribution curve varied between $80 \mathrm{~nm}$ and $500 \mathrm{~nm}$ with an average size distribution of $123 \mathrm{~nm}$, the polydispersity index (PdI) of 0.059 approximate 0.06 is considered to be a monodispersed solution. This result coincides with Lieberman et al. in their 1998 book, where they state that polymer dispersions with a PdI between 0.03 and 0.06 are considered to be monodispersed solutions. The polydispersity index (PdI) doubled (figure 9) showing some instability after one week of storage and remained stable after 10 more days of storage (figure 10).

In figure 11 , the $\mathrm{MgOCl}_{2}$ liposomes size distribution curve varied between $50-500 \mathrm{~nm}$ with an average size of $108 \mathrm{~nm}$. The polydispersity index of 0.093 approximately 0.1 , is in the range of $0.1-0.2$ which is generally found in colloidal drug carriers (Lieberman, Rieger et al. 1998), suggesting that $\mathrm{MgOCl}_{2}$ drug was encapsulated within the liposomes. $\mathrm{MgOCl}_{2}$ liposomes showed more stability than empty liposomes in storage for one week (figure 12) the PdI average size distribution remained stable, on the third week of storage $\mathrm{MgOCl}_{2}$ liposomes PdI increased also the average size (figure 13) suggesting the starting of liposome degradation.

The size distribution curve of the empty liposomes and $\mathrm{MgOCl}_{2}$ liposomes showed more than one peak with PdI of 0.283 and 0.653 after 4 weeks of storage at $4^{\circ} \mathrm{C}$ respectively. The formation of new peaks of large size $(800 \mathrm{~nm})$ observed in figure 15 suggests that some liposomes were coalescing. In addition, the shift in the peak of the empty liposomes average size distribution curve to the left suggests that many small lipid 
particles (in the range of $20-100 \mathrm{~nm}$ ) related to the degradation of the liposomes were in the solution, causing a shift in the size distribution curve to the left. The high polydispersity index (above 0.2 ) observed in the size distribution curve for the empty liposomes size distribution curve also indicated a broad size distribution, as the particle size range varied from 20-1000 $\mathrm{nm}$ (figure15).

In figure 17, the formation of a peak in the area between $10-30 \mathrm{~nm}$ with an average size of $17 \mathrm{~nm}$, suggested that this peak represents free $\mathrm{MgOCl}_{2}$ particles, meaning that the liposomes contained $\mathrm{MgOCl}_{2}$ particles and that it remained within the liposomes for 3-4 weeks days until the liposomes started degrading. This means that particles of lipids or $\mathrm{MgOCl}_{2}$ nanoparticles made a broader size distribution curve thus affecting the PId and size distribution average values of the size distribution curve (figure 17).

More than one peak in the liposome size distribution curve was observed for the $\mathrm{MgOCl}_{2}$-immunoliposomes after 10 days of storage at $4^{\circ} \mathrm{C}$. The short life of the $\mathrm{MgOCl}_{2}$-immunoliposomes is related to an increase in antibody instability after dilution. Antibodies become unstable after dilution, which in turn makes them oxidize, the oxidation of the antibody may have made liposome degradation hastened. A technical resource article written by Thermo Scientific Company Pierce Products, suggests to add a carrier protein or a filler protein, like Bovine Serum Albumin, to the diluted antibody to protect it against degradation (Pierce 2005). The addition of the filler protein, a protein stabilizing cocktail or a cryoprotectant agent to the $\mathrm{MgOCl}_{2}$-immunoliposomes should increase their shelf life, but more studies need to be performed in order to determine the effect of the addition of these agents on the effectiveness of $\mathrm{MgOCl}_{2}$-immunoliposomes as a bactericidal agent. 
A BCA assay standard curve was used to determine the total protein concentration present in the Antibody-Streptavidin complex which attaches to the surface of the liposome after the dilutions and purification. The theoretical concentration of antibody after dilutions was of $90.0 \mu \mathrm{g} / \mathrm{ml}$ and after the purification the total concentration of the Streptavidin-antibody complex obtained was $44.2 \mu \mathrm{g} / \mathrm{ml}$. A ratio of 1:1 of StreptavidinAntibody complex to $\mathrm{MgOCl}_{2}$ liposomes was used to develop the immunoliposome, and the concentration of Streptavidin-Antibody in the liposome solution was approximately $22.1 \mu \mathrm{g} / \mathrm{ml}$. This low concentration might be the cause of the low reduction percentage concentration and given the results obtained for the reduction percentages of the bacteria treated with the $\mathrm{MgOCl}_{2}$ immunoliposomes a higher concentration of antibody and Streptavidin should be tested in order to find the Streptavidin-Antibody concentration that will give optimum results for bacterium targeting.

The results from the Minimum Inhibitory Concentration assay for $B$. thuringiensis (figure 21) showed that after a period of 22 hours of bacterial incubation with the $\mathrm{MgOCl}_{2}$, drug concentrations of $2.0 \mathrm{M}, 1.0 \mathrm{M}, 0.5 \mathrm{M}$, and the $\mathrm{MgOCl}_{2}$ liposomes caused an absolute bacterial growth inhibition. The control plate (HEPES) and $\mathrm{MgOCl}_{2}$ of $30 \mathrm{mM}$ and lower showed bacterial growth after the 22 hours period. The importance of these results is the observation of an absolute bacterial growth inhibition caused by the $\mathrm{MgOCl}_{2}$ liposomes after the 22 hours of incubation.

Bacillus thuringiensis was incubated with the liposomes to determine the growth inhibition percentage of the bacteria in contact with the liposomes at three different times- 0,1 , and 2 hours in the Colony Growth Assay (CGA). The highest average reduction percentage (58\%) of $B$. thuringiensis was obtained after 1 hour of incubation 
with $\mathrm{MgOCl}_{2}$ liposomes. The statistical analysis also revealed that the reduction percentage was significant in comparison with the controls (HEPES and Empty liposomes). The drug concentration inside the liposomes remains unknown. Assuming a $25 \%$ drug encapsulation efficiency, the approximated drug concentration of these liposomes was $0.75 \mathrm{mM}$ and the reduction percentage obtained from the bacteria incubated with the $3 \mathrm{mM} \mathrm{MgOCl}$ free drug was smaller than the reduction obtained for the $\mathrm{MgOCl}_{2}$ liposomes. This suggests that the $\mathrm{MgOCl}_{2}$ liposomes contributed to the $\mathrm{MgOCl}_{2}$ delivery through the membrane cell wall of the bacteria, causing a higher bacterial reduction within 1 hour. Empty liposomes caused the $2^{\text {nd }}$ highest bactericidal effect, at time 1 hour, this result showed statistical significance in the t-test performed. The average of the bacterial reduction percentage of the empty liposomes increased due to the reduction percentage of test \#3 (see table3). The high bacterial reduction caused by the empty liposomes on that particular test could be due to an unexpected degradation of the empty liposomes or a change in $\mathrm{pH}$ in the empty liposomes solution, causing cytotoxicity to $B$. thuringiensis cells. The average bacterial reduction effect caused by $\mathrm{MgOCl}_{2}$-immunoliposomes was lower than the effect of $\mathrm{MgOCl}_{2}$ liposomes, since test \#1 and \#4 showed no bacterial reduction effect. There are several reasons that can explain the low bacterial reduction caused by the $\mathrm{MgOCl}_{2}$ immunoliposomes, random orientation of the antibodies may have cause lower specificity and lower reduction. Also, the functionality of the antibody may have been affected after the Streptavidin-antibody complex attachment to the liposomes. It is necessary to perform a functionality test on the $\mathrm{MgOCl}_{2}$-immunoliposomes in order to determine if the low reduction percentages obtained with the $\mathrm{MgOCl}_{2}$-immunoliposomes is due to the lost of functionality of the 
antibody. Free $\mathrm{MgOCl}_{2}(3 \mathrm{mM})$ drug did not show a bacterial reduction in 3 of the 4 tests performed, this suggests that $3 \mathrm{mM}$ of free $\mathrm{MgOCl}_{2}$ is not a sufficient amount to cause a bactericidal effect to $B$. thuringiensis in 1 hour of treatment.

In the CGA the highest bacterial reduction effect at 2 hours of incubation was caused by the empty liposomes. The high average reduction percentage in the empty liposomes is the result of the high reduction percentage observed on tests \#1 and \#4. Due to the high variability obtain within each test in the CGA, a test like a fluorescenceactivated cell sorter (FACS) should minimizes the experimental error and should be used in future studies for a better quantification of the bactericidal effect of the $\mathrm{MgOCl}_{2}$ liposomes and $\mathrm{MgOCl}_{2}$-immunoliposomes. Halwani, used FACS to confirm interactions of liposomes with bacterial membranes, and it would be practical for the confirmation of the efficacy of the bactericidal effect for the application in this research (Halwani, Mugabe et al. 2007). In order to get into additional conclusions with a CGA, a larger population of samples should be used to obtain statistical results with smaller variability values.

The bactericidal effectiveness of the $\mathrm{MgOCl}_{2}$ liposomes observed in the CGA was better for the treatment of $B$. thuringiensis after 1 hour of incubation than after 2 hours. This result was because the bacteria that remained alive after the $1^{\text {st }}$ hour of incubation kept on replicating in the $2^{\text {nd }}$ hour of incubation; therefore, the reduction percentage diminished. This means that $\mathrm{MgOCl}_{2}$ liposomes are capable of affecting the cell wall of the bacteria, but the concentration of $\mathrm{MgOCl}_{2}$ inside the liposomes is not sufficient to exterminate all the bacterium present in the solution in a period of 2 hours. Better results 
would have been obtained if the cells were incubated only with $\mathrm{MgOCl}_{2}$ liposomes, instead of in a 1:1 ratio of $\mathrm{MgCl}_{2}$ liposomes to bacterial solution in $\mathrm{LB}$ broth.

It is stated in the product information sheet of Meridian Science Co. that the rabbit anti-Bacillus spores antibody used to make the $\mathrm{MgOCl}_{2}$-immunoliposomes are reactive with $B$. cereus and $B$. subtilis spores and vegetative cells, but the antibody can cross-react with other $\mathrm{B}$ acillus species. The $\mathrm{MgOCl}_{2}$-immunoliposomes incubated with B. thuringiensis showed a lower average reduction percentage than the $\mathrm{MgOCl}_{2}$ liposomes. These results can be due to the presence of the antibody on the surface of the liposomes, since the antibody attached to the surface of the liposomes is not against $B$. thuringiensis a lower interaction between liposomes and the membrane of the bacteria was observed. The low bactericidal reduction observed for the immunoliposomes could be due to a small cross-reaction of $B$. thuringiensis with the antibody on the liposomes or the production of a small quantity of B. thuringiensis CryA toxins which cause liposomal membrane permeation promoting the $\mathrm{MgOCl}_{2}$ release (Du 2005). Also, the low bactericidal effect could be due to the lost of functionality in the antibody after the crosslinking reaction with the Streptavidin and after linking it with the liposomes. For the future use of this $\mathrm{MgOCl}_{2}$-immunoliposome to detect only B. anthracis, a monoclonal antibody specific for the B. anthracis poly-D- $\gamma$-glutamic acid capsule, will be the best choice.

The live/dead assay results demonstrated statistically significant reduction rates of B. thuringiensis compared to HEPES at 1 hour of incubation, with $\mathrm{MgOCl}_{2}-$ immunoliposomes and $\mathrm{MgOCl}_{2}$ liposomes, with averages reduction percentages of 29.7 and 31.7 respectively. The $\mathrm{p}$ value of the $\mathrm{MgOCl}_{2}$ liposomes $(0.014)$ is larger than the $\mathrm{p}$ 
value of the $\mathrm{MgOCl}_{2}$-immunoliposomes $(0.0017)$, this states that the reduction percentages observed for the $\mathrm{MgOCl}_{2}$-immunoliposomes is statistically more significant than the reduction percentage of the $\mathrm{MgOCl}_{2}$-liposomes, due to a higher variance observed in the $\mathrm{MgOCl}_{2}$-liposomes. The free $\mathrm{MgOCl}_{2}$ at concentration of $3 \mathrm{mM}$ also showed a statistically significant reduction percentage with a p value of 0.036 . This $p$ value is large compared to the $\mathrm{p}$ values of $\mathrm{MgOCl}_{2}$-immunoliposomes and $\mathrm{MgOCl}_{2}$ liposomes due to the lower average reduction percentage observed in B. thuringiensis treated with the free $\mathrm{MgOCl}_{2}$ and due to a high variability between the samples. The statistical analysis and the reduction percentages caused by the aforementioned liposomes compared to the HEPES (control) suggests that $\mathrm{MgOCl}_{2}$ liposomes and $\mathrm{MgOCl}_{2}$ immunoliposomes are better bactericides for B. thuringiensis than $3 \mathrm{mM}$ of $\mathrm{MgOCl}_{2}$. Since the encapsulation percentage of the liposomes is $25 \%$, the concentration of $\mathrm{MgOCl}_{2}$ within the $\mathrm{MgOCl}_{2}$-liposomes and $\mathrm{MgOCl}_{2}$-immunoliposomes is lower than $3 \mathrm{mM}$. The statistical analysis performed to compare the effect of empty liposomes with $\mathrm{MgOCl}_{2}$ liposomes (p value 0.00055$), \mathrm{MgOCl}_{2}$ immunoliposomes ( $\mathrm{p}$ value 0.016 ) and $3 \mathrm{mM} \mathrm{MgOCl}$ ( $\mathrm{p}$ value 0.037 ), showed significant reduction percentages for the 3 aforementioned solutions. In this comparison free $3 \mathrm{mM} \mathrm{MgOCl}$ showed a significant reduction percentage but its average reduction percentage compared to the $\mathrm{MgOCl}_{2}$ liposomes and $\mathrm{MgOCl}_{2}$ immunoliposomes is lower.

The live/dead assay for $B$. thuringiensis suggests that the $\mathrm{MgOCl}_{2}$-liposomes and $\mathrm{MgOCl}_{2}$-immunoliposomes were effective in the drug transportation to the bacteria; this result suggests that a higher bactericidal effect can be accomplished if a higher drug concentration is encapsulated within the liposomes. In order to make sure that an 
interaction between the bacteria and the liposomes is actually taking place some signaling assays can be performed such as Atomic Force Microscopy (AFM) or Transmission Electron Microscopy (TEM) can be used to observe the damage on the membrane cell wall of the bacteria caused by the liposomes.

In the live/dead assay comparing the effect of the empty liposomes at time 0 hours compared to 1 hour, the empty liposomes had no harmful effect on the B. thuringiensis cells, supporting the hypothesis that the empty liposomes have a minimum effect in bacterial cells cytotoxicity (see appendix J for statistical analysis). This result supports the need of additional experiments to abandon the suspicion of empty liposomes cytotoxicity observed in the colony growth after two hours of empty liposomes incubation with bacterial cells.

B. subtilis live/dead assay average reduction percentages after 1 hour of incubation for the $\mathrm{MgOCl}_{2}$ liposomes and $\mathrm{MgOCl}_{2}$-immunoliposomes were 45.56 and 34.4 respectively. Statistical analysis comparing the effect of HEPES vs. $\mathrm{MgOCl}_{2}$ liposomes and $\mathrm{MgOCl}_{2}$-immunoliposomes showed significant bactericidal effects only in the $\mathrm{MgOCl}_{2}$ liposomes ( $\mathrm{p}$ value 0.0065 ). The non-significant reduction percentage result observed for the immunoliposomes compared to the HEPES is due to a low bacterial reduction percentage observed in test $\# 2$ where the reduction percentage of HEPES is similar to the reduction percentage caused by the $\mathrm{MgOCl}_{2}$-immunoliposomes. The statistical analysis observed comparing the effect of empty liposomes at 1 hour compared to the $\mathrm{MgOCl}_{2}$ liposomes and $\mathrm{MgOCl}_{2}$-immunoliposomes showed a statistically significant reduction percentage for both solutions suggesting that they acted as good drug carriers for $B$. subtilis. 
The higher reduction percentages obtained for the treatment of $B$. subtilis with $\mathrm{MgOCl}_{2}$-immunoliposomes compared to the effect of the immunoliposomes for $B$. thuringiensis are due to the detection of the antibody attached to the surface of the liposome by the antigens in B. subtilis, this identification caused the better drug release than immunoliposomes with $B$. thuringiensis. Moreover, a higher reduction percentage was observed for the treatment of $B$. subtilis with the $\mathrm{MgOCl}_{2}$ - liposomes. This might be caused by a higher sensitivity of $B$. subtilis to the drug, and suggests that the immunoliposomes should be improved by the addition of a higher concentration of the Streptavidin-Antibody complex in order to obtain better reduction percentages results caused by the $\mathrm{MgOCl}_{2}$-immunoliposomes. A higher reduction percentage caused by the $\mathrm{MgOCl}_{2}$-immunoliposomes incubation with $B$. subtilis was expected. The antibody attached to the surface of the liposomes is against the bacterium B. subtilis and B. cereus the unexpected low reduction percentage caused by the $\mathrm{MgOCl}_{2}$-immunoliposomes could be due to a lost in functionality of the antibody in the crosslinking procedure.

The results obtained in this test for $B$. cereus showed a similar reduction percentage and statistically non significant, between the bacteria treated with HEPES buffer; empty liposomes; $\mathrm{MgOCl}_{2}$ liposomes; $\mathrm{MgOCl}_{2}$-immunoliposomes $(30.5 ; 30.7$; 30.4; and 30.2 respectively). This result could be due to a low $\mathrm{pH}$ of the HEPES buffer and the presence of hydrogen peroxide due to light exposure of the buffer.

In a study by Hamouds 1999 , they investigated the sporicidal properties of 2 antimicrobial lipid emulsions, in order to eliminate human toxicity caused by the sporicidal agents by itself. In this study, they observed a high sporicidal effect $(98 \%)$ on 
B. cereus and $B$. subtilis caused by the lipid nanoemmulsions after 4 hours of treatment.

In the same study they used transmission electron microscopy (TEM) to observe the physical damage in the bacterial spores caused by their nanoemmulsion (Hamouda, Hayes et al. 1999). The use of TEM would be a good approach to corroborate the $\mathrm{MgOCl}_{2}$ liposomes and $\mathrm{MgOCl}_{2}$-immunoliposomes interaction with the membrane cell wall of the Bacillus bacterium studied in this thesis.

To my knowledge, this is the first study that applies nano-liposome technology to encapsulate $\mathrm{MgOCl}_{2}$ with the purpose to be treated as a bactericidal agent. Previous studies performed by Stoimenov group with free $\mathrm{MgOCl}_{2}$ nanoparticles used as a bactericidal agent for the treatment of E. coli, B. megaterium and B. subtilis, showed promising results of the effect on this nanoparticles as a disinfectant. In this particular study AFM imaging and TEM imaging was used to observe the nanoparticles effect on the bacteria. It showed a strong and fast effect on the killing influence of the $\mathrm{MgOCl}_{2}$ nanoparticle effect on the killing action of both bacterial cells and spores (Stoimenov 2002). In the research perfomed by Stoimenov (2002) no reduction percentages of bacteria caused by the presence of $\mathrm{MgOCl}_{2}$-particles were calculated.

With the purpose of applying the $\mathrm{MgOCl}_{2}$ nanoparticles as biowarfare defense agent, to increase the intracellular drug concentrations through fusion with bacterial cells membranes, $\mathrm{MgOCl}_{2}$ was encapsulated in liposomes. The attempt of a quantification of its bactericidal effect was performed in our studies. The tendency on the bactericidal effect caused by the $\mathrm{MgOCl}_{2}$ liposomes toward B. subtilis and B. thuringiensis coincides with the results that Stoimenov group obtained in the treatment of $B$. megaterium and $B$. subtilis with free $\mathrm{MgOCl}_{2}$ nanoparticles. Low $\mathrm{MgOCl}_{2}$ concentrations encapsulated 
within the liposomes caused better reduction percentages than higher free drug concentrations. The obtained results are promising, since low concentrations of encapsulated $\mathrm{MgOCl}_{2}$ within the liposomes caused some bactericidal effect within 2 hours. However, the system has room for improvement, if a higher drug concentration could be encapsulated in the liposomes higher reduction percentages can be achieved in a smaller amounts of time. Also, the functionality of the antibody attached to the liposomes has to be tested in order to determinate the $\mathrm{MgOCl}_{2}$-immunoliposomes specificity, in a study by Schnyder 2004, they used immunocytochemistry and determined the cellular uptake of an antibody in a Streptavidin-antibody complex (Schnyder, Krahenbuhl et al. 2004). For better accuracy in the quantification of the reduction percentages caused by the bacteria a Fluorescence Activated Cell Sorting (FACS) system is highly recommended, also methods such as AFM or TEM can be used to observe the damage on the membrane cell wall of the bacteria caused by the liposomes. 


\subsection{CONCLUSION}

In this thesis, liposomes of average size of $130-90 \mathrm{~nm}$ were developed, with a shell life of 15 days. The liposomes were modified with a polyclonal antibody against the Bacillus cereus and Bacillus subtilis antigens. The drug delivery efficacy of both liposomes was tested in two different forms, a colony growth assay (CGA) and a Live/Dead assay.

The bacterial viability of $B$. subtilis and B. thuringiensis tested using a live/dead assay revealed that bacterium treated with the $\mathrm{MgOCl}_{2}$ liposomes experienced a statistically significant reduction percentage, compared to HEPES and empty liposomes, with average reduction percentages of 45.6 and 31.7 respectively. The results of the bacteria $B$. cereus in the live/dead assay did not show a statistically significant bactericidal effect of the liposomes. $\mathrm{MgOCl}_{2}$ immunoliposomes showed a lower bactericidal effect toward the bacterium cells, compared to the $\mathrm{MgOCl}_{2}$ liposomes bactericidal effect, this could be due to a lost of functionality during the crosslinking procedure of the antibody to the liposomes. Immunocytochemistry tests, as well as competition and uptake experiments, should be performed to corroborate the antibody functionality after the crosslinking procedure.

The results of the CGA, revealed a statistical significant bacterial reduction percentage for the $\mathrm{MgOCl}_{2}$ liposomes at time 1 hour compared to HEPES and empty liposomes. At time 2 hours the CGA revealed a statistical significant bacterial reduction percentage for the $\mathrm{MgOCl}_{2}$ liposomes compared with HEPES. Non-statistically significant bactericidal results were observed for the $\mathrm{MgOCl}_{2}$-immunoliposomes. The non-statistically significance observed in the bactericidal effect of the $\mathrm{MgOCl}_{2}$ - 
immunoliposomes is due to a low bactericidal effect observed in the CGA compared to the HEPES and empty liposomes. Finally, empty liposomes caused a high average reduction percentage since 2 of the 4 tests performed revealed $100 \%$ of bactericidal effect. Due to the high variability observed in the CGA test, further conclusions cannot be drawn regarding to the $\mathrm{MgOCl}_{2}$ liposomes efficacy, what can be pointed is that the $\mathrm{MgOCl}_{2}$-liposomes showed the highest bacterial reduction in each of the tests, compared to the $\mathrm{MgOCl}_{2}$-immunoliposomes and $3 \mathrm{mM} \mathrm{MgOCl}$ free drug.

The results presented in this thesis reveal a tendency of $\mathrm{MgOCl}_{2}$ liposomes as a bactericidal agent for $B$. thuringiensis and B. subtilis, suggesting this is an effective bactericidal agent. Lower reduction percentages were caused by the $\mathrm{MgOCl}_{2}$ immunoliposomes compared to the $\mathrm{MgOCl}_{2}$ liposomes.

In order to obtain better bacterial targeting effect a monoclonal antibody with a concentration higher than $44.2 \mu \mathrm{g} / \mathrm{ml}$ of the Streptavidin-Antibody complex should be attached to the liposome surface. Further research is still necessary to improve the drug encapsulation efficiency; also for the corroboration of the efficacy of the $\mathrm{MgOCl}_{2}$ liposomes and $\mathrm{MgOCl}_{2}$-immunoliposomes compared to the empty liposomes. In addition the determination of the exact mechanism of $\mathrm{MgOCl}_{2}$-liposomes and $\mathrm{MgOCl}_{2}-$ immunoliposomes between the liposomes and the membrane cell wall of the bacteria is recommended in order to further improve this drug delivery system. Moreover, additional studies such as Fluorescent Activated Cell Sorting (FACS), Atomic Force Microscopy (AFM), and Transition Electron Microscopy (TEM) are recommended in order to confirm liposome interactions with the bacterial membrane. 


\section{REFERENCES}

Becker, M. (2007). Liposome Processing Optimization. Biomedical Engineering. Miami Florida International University. Masters 44.

Committee to Update Science, M., and Animals, National Research Council (2004). Science, Medicine, and Animals Washington DC.

Davis, M. L. and D. A. Cornwell (1991). Introduction to environmental engineering. Boston, McGraw-Hill.

Dietrich, R., Fella, C., Strich, S., et al. (1999). "Production and Characterization of Monoclonal Antibodies against the Hemolysin BL Enterotoxin Complex Produced by Bacillus cereus." Applied Environmental Microbiology 65: 4470-4474.

Du, C., Wing Chan, McKeithan, T. W., et al. (2005). "Surface Display of Recombinant Proteins on Bacillus thuringiensis Spores." Applied Environmental Microbiology 71: 3337-3341.

Eduards, K. A., Clancy, H. A., and Baeumner, A. J. (2006). "Bacillus anthracis: toxicology, epidemiology and current rapid detection mehtods." Anal Bioanal Chem 384: 73-84.

Geny, B. and M. R. Popoff (2006). "Bacterial protein toxins and lipids: pore formation or toxin entry into cells." Biol Cell 98: 667-678.

Halwani, M., C. Mugabe, et al. (2007). "Bactericidal Efficacy of liposomal aminoglycosides against Burkholderia cenocepacia." Journal of antimicrobial chemotherapy 60: 760-769.

Hamouda, T., M. M. Hayes, et al. (1999). "A novel surfactant nanoemulsion with broadspectrum sporicidal activity against Bacillus species." The Journal of Infectious Diseases 180: 1939-1949.

Holovati, J. L. and J. P. Acker (2007). "Spectrophotometric measurement of intraliposomal trehalose." Cryobiology 55: 98-107.

Hua, C. C., Chang, T. C., and Ding, H. C. (2002). Methods for rapid identification of Bacillus cereus 20020146752.

Incorporation, M. (2006). Hepes (free acid) Product Information. Product Information Mediatech, Mediatech: 1. 
John A. Jernigan, D. S. Stephens, et al. (2001). "Bioterrorism-Related Inhalational Anthrax:The First 10 Cases Reported in the United States." Emerging Infectious Diseases 7(6): 933-944.

K. Todar, " U. o. W. M. D. o. Bacteriology, Ed., 2005 (2005). Textbook of bacteriology. Madisson, University of Wisconsin, Department of Bacteriology.

Kim, Y.-m., S. Farrah, et al. (2007) Membrane damage of bacteria by silanolstreatment. Electronic Journal of Biotechnology Volume, 252-259 DOI:

Koo, K., P. M. ForEgeding, et al. (1998). "Development of a streptavidin-conjugated single chain antibody that binds Bacillus cereus spores." Applied Environmental Microbiology 64(7): 2497-2502.

Koper, O., J. Klabunde, et al. (2002). "Nanoscale Powders and Formulations with Biocidal Activity Toward Spores and Vegetative Cells of Bacillus Species, Viruses, and Toxins." Current Microbiology 44: 49-56.

Lambert, P. A. (2002). "Cellular impermeability and uptake of biocides and antibiotics in Gram-positive bacteria and mycobacteria." Journal of Applied Microbiology Symposium Supplement 92: 46S-54S.

Lasic, D. D. (1998). "Novel Applications of liposomes." Tibtech 16: 307-321.

Lenski, R. E. (1998). "Bacterial evolution and the cost of antibiotic resistance." International Microbiology 1: 265-270.

Lepe-Zuniga, J. L., J. S. Z. Jr., et al. (1987). "Toxicity of life exposed Hepes media." Journal of Immunological Methods 103: 145.

Lieberman, H. A., M. M. Rieger, et al. (1998). Pharmaceutical Fosage Forms: Disperse Systems. New York, Informa Health Care.

Lo, Y.-S., Huefner, N. D., Chan, W. S., et al. (1999). "Specific Interactions between Biotin and Avidin Studied by Atomic Force Microscopy Using the Poisson Statistical Analysis Method." Langmuir 15.

Madigan, M. and J. Martinko (2005). Brock Biology of Microorganisms. Upper Saddle River, Prentice Hall.

Malmsten, M. (2002). " Surfactants and Polymers in Drug Delivery." New York Marcel Dekker Inc. 122. 
Mesnage, S. and E. Tosi-Courture (1998). "The capsule and S layer: Two independent and yet compatible macromolecular structures in Bacillus anthracis " Journal of Bacteriology 180: 52-58.

Mori, S. and H. G. Barth (1999). Size Exclusion Chromatography. New York, Springer.

Mugabe, C., A. O. Azghani, et al. (2005). "Preparation and characterization of dehidration-rehydration vesicles loaded with aminoglycosides and microlide antibiotics." International journal of pharamceutics 307: 244-250.

Nolen, R. S. (2003). "Though better prepared after 9/11, America still vulnerable to bioterrorism " AVM Journal.

Pierce Company, T. S. (2000). "MBS and Sulfo MBS instructions." Retrieved April 2, 2007, 2008.

Pierce Company, T. S. (2006). Pierce BCA Protein Assay Kit Instruction

Pierce, T. S. (2005). "Protein Stability and Storage." Technical Resource.

Probes, M. (2001). "HEPES (Molecular Probes product description) " Retrieved April 2, 2008, from http://www.mpbio.com/product_info.php?products_id=15884.

Probes, M. (2004). Live/Dead Baclight Bacterial viability kits, Molecular Probes.

R., J. (1978). "Escherichia coli ribosomes by protein modification with 2-iminothiolane (methyl 4-,ercaptobutyrimidate)." Biochem J. 17(25): 5399-5406.

Ratner, B. D., A. S. Hoffman, et al. (2004). Biomaterials Science. San Diego California, Elsevier Academic Press.

Sabin, J., G. Prieto, et al. (2006). "Size and stability of liposomes: A possible role of hydration and osmotic forces." The European Physical Journal E. 20: 401-408.

Schnyder, A., S. Krahenbuhl, et al. (2004). "Targeting of skeletal muscle in vitro using biotinylated immunoliposomes." Biochem J. 377: 61-67.

Sederatou, Z., D. Tsiourvas, et al. (2000). "Molecular recognition of Complementary Liposomes: The Enhancing role of cholesterol." Langmuir 16: 9186-9191.

Segota, S. and D. Tezak (2006). "Spontaneous Formation of vesicles." Advances in colloid and interface science 121(1-3): 51-75.

Stoimenov, P. K., Klinger, R. L., Marchin, G. L., et al. (2002). "Metal Oxide Nanoparticles as Bactericidal Agents." Langmuir 18: 6685-6693. 
Sue, D., A. R. Hoffmaster, et al. (2006). "Capsule production in B. cereus strains associated with severe pneumonia." Journal of clinical microbiology 44(9): 3426-3428.

Swiecki, M. K., Lisanby, M. W., Shu, F., et al (2006). "Monoclonal Antibodies for Bacillus anthracis Spore Detection and Functional Analyses of Spore Germination and Outgrowth." The Journal of Immunology 176: 6076-6084.

Theeraporn Puntheeranurak, C. S., Rong Zhu, Chanan Angsuthanasombat, Peter Hinterdorfer (2005). "Structure and distribution of the Bacillus thruringiensis Cry4Ba toxin in lipid membranes." Ultramicroscopy 105: 115-124.

Weyant, R. S., J. W. Ezzell, et al. (2001). Basic Laboratory Protocols for the presumptive identification of Bacillus anthracis. Centers for Disease Control and Prevention. 1: 1-16.

Wolfgang Frey, W. R. S., Jr., Daniel W. Packt, Chao-Tsen Chent, Ashutosh Chilkoti, Patrick Stayton, Viola Vogel, and Frances Arnold (1996). "Two-dimensional protein crystallization via metal-ion coordination by naturally occurring surface histidines." Biophysics 93: 4937-4941.

Zayas, R. d. (2006). Detection and neutralization of bactericidal biohazards via nanoencapsulation Biomedical Engineering. Miami, Florida International University. Masters of Science: 92. 


\section{APPENDIX}

\section{Appendix A. Liposome development}

1. Weight $87.5 \mathrm{mg}$ of Phosphatidylcholine, $37.5 \mathrm{mg}$ of PEG 2000 Biotin, and $6.5 \mathrm{mg}$ of Cholesterol.

2. Place the weighted lipids in a round bottom flask and add $50 \mathrm{ml}$ of chloroform in the chemical hood. Mix the lipids with the chloroform until no particles can be observed.

3. Put a piece of parafilm around the neck of the flask before removing the flask form the hood. Place the flask in the water bath of the rotovapor at $40^{\circ} \mathrm{C}$, turn on the vaccum, set the flask rotation 155 RPM, and wait one hour for the chloroform to completely evaporate.

4. After the film is made take the round bottle from the rotovapor, use a kimwipe and an elastic rubber to cover the neck of the flask.

5. Dip the flask 3 times in liquid Nitrogen.

6. Place the round bottom flask in the lyophilizer flask and leave it in the lyophilizer over night.

7. After the overnight lyophilization, remove the flask from the lyophilizer and add $35 \mathrm{ml}$ of $1 \mathrm{M} \mathrm{pH} 7$ HEPES buffer.

8. Set the water bath of the rotovapor to $40^{\circ} \mathrm{C}$ and the circulator to $14^{\circ} \mathrm{C}$.

9. Put the flask in the rotovapor at $100 \mathrm{RPM}$ for 45 minutes verify that there is no film attached to the bottom of the flask.

10. Weight $12.5 \mathrm{mg}$ of $\mathrm{MgOCl}_{2}$ in the scale and add it to the liposome solution.

11. Place the liposome solution on the rotovapor at the same conditions mentioned on step 8 and wait 15 minutes.

\section{Appendix B. Liposome extrusion protocol}

1. Clean the $100 \mathrm{~mL}$ extruder parts with HEPES before adding the liposome solution in it.

2. Connect the pressure "pipe" with the extruder.

3. Place the supporter and the $100 \mathrm{~nm}$ membrane filter in the tank.

4. Make an extrusion with $10 \mathrm{ml}$ of HEPES to remove any residual particles from the extruder.

5. Add $15 \mathrm{~mL}$ of the liposomes into the extruder.

6. Open the Argon tank and increase the pressure to $100 \mathrm{psi}$, open the valve that connects the tank with the extruder (green valve) and close the release pressure valve (black valve), keep on increasing the pressure until liposomes start coming out of the extruder. If the liposomes stop from getting out of the extruder increase the pressure 100 psi until the batch of liposomes is completely extruded.

7. Repeat this extruding procedure five times.

8. After the fifth time change the membrane filter and add $2 \mathrm{ml}$ of $2 \%$ Trehalose 3 mM HEPES. Repeat step 7 and 8 for a total of 15 extrusions. 
9. Change the membrane filter to $80 \mathrm{~nm}$ and repeat steps 7 and 8 . Add $1 \mathrm{ml}$ of $10 \%$ Trehalose $3 \mathrm{mM}$ solution after every five extrusions, before changing the filter.

10. Measure the liposome size in the nanosizer. If the size of the liposomes is in the range of 120 to $100 \mathrm{~nm}$ the liposomes are ready for purification, if not the extrusion procedure will be repeated with a $50 \mathrm{~nm}$ membrane filter.

11. To prepare the Sephadex G-50 weight $25 \mathrm{~g}$ of Sephadex.

12. Add $250 \mathrm{ml}$ of HEPES to the $25 \mathrm{~g}$ of Sephadex.

13. Let the mix swell at room temperature for 3 hours or at $90^{\circ} \mathrm{C}$ for one hour.

14. While waiting for the Sephadex to swell, place some glass wool in HEPES buffer.

15. When the Sephadex is swelled cut some of the glass wool and place it inside a 10 $\mathrm{ml}$ syringe, and fill the syringe with swelled sephadex-G50 to the $7 \mathrm{ml}$ mark.

16. Place the column in a $50 \mathrm{ml}$ plastic flask and place it in the centrifuge to spin for 3 minutes at $1000 \mathrm{~g}$.

17. Place $2.5 \mathrm{ml}$ of $\mathrm{MgOCl}_{2}$ liposomes in the column and place the column inside a $50 \mathrm{ml}$ plastic flask.

18. Spin the columns containing the liposomes for 10 minutes at $50 \mathrm{~g}$, and for 3 additional minutes at $1000 \mathrm{~g}$.

\section{Appendix C. Synthesis of Streptavidin- antibody complex}

1. Vortex the antibody for 30 seconds. Dilute it in $2 \mathrm{ml}$ of $1 \mathrm{M}$ HEPES $\mathrm{pH} 7$.

2. Dissolve $1 \mathrm{mg}$ of TRAUTS reagent into $200 \mu 1$ of HEPES.

3. Add a 40:1 molar excess TRAUTS:Antibody.

4. Place it in a stirred water bath at room temperature for one hour.

5. Purify the complex in a Sephadex G-25 column, previously prepared.

6. In order to prepare the MBS dissolve $3.14 \mathrm{mg}$ of MBS into $1 \mathrm{~mL}$ of DMSO

7. Vortex the streptavidin nanobeads for 30 seconds.

8. Dilute $40 \mu \mathrm{l}$ of Streptavidin in $5.0 \mathrm{ml}$ of $16.0 \mathrm{mM}$ of HEPES buffer.

9. Add a 40:1 molar excess of MBS:Streptavidin by adding $200 \mu \mathrm{l}$ of MBS to $40 \mu \mathrm{l}$ of diluted Streptavidin.

10. Mix $150 \mu \mathrm{l}$ of Streptavidin- MBS complex with $500 \mu \mathrm{l}$ of Trauts-Antibody.

11. Gently stir the mixture overnight in a water bath at room temperature.

12. Add a 1:1 ratio of liposomes and Streptavidin-Antibody complex, stir it in a water bath for 1 hour at room temperature. 


\section{Appendix D. BCA assay enhanced protocol}

1. Pipette $25 \mu \mathrm{l}$ of each standard or unknown sample replicate into a microplate 96 well plate.

2. Add $200 \mu$ l of the working reagent (WR) to each well and mix plate thoroughly on a plate shaker for 30 seconds.

3. Cover plate and incubate at $60^{\circ} \mathrm{C}$ for 30 minute.

4. Cool plate to room temperature (RT) for 30 minutes.

5. Measure the absorbance at $595 \mathrm{~nm}$ on a plate reader.

\section{Appendix E. Bacterial preparation}

1. The bacteria is located at $-80^{\circ} \mathrm{C}$ freezer, remove the bacteria from the freezer and thaw, by rubbing the vial in your hands for 1 minute.

2. Streak the bacteria in a Luria Bertani agar Petri dish and incubate overnight at physiological conditions.

3. Select an isolated colony for inoculation in $10 \mathrm{ml}$ of LB broth in a shaking incubator at physiological conditions overnight.

4. Dilute the overnight culture and measure its absorbance in a spectrophotometer at $600 \mathrm{~nm}$.

\section{Appendix F. Colony growth assay}

1. Make a 1:10 dilution of the overnight inoculated culture five times for a concentration of $\left(1 \times 10^{5} \mathrm{cells} / \mathrm{ml}\right)$. Make an OD $600 \mathrm{~nm}$ abosorbance measurement. 2. Mix well $500 \mu \mathrm{l}$ of the diluted bacteria with $500 \mu \mathrm{l}$ of HEPES buffer in vial 1 .

3. Repeat step 2 for Empty liposomes, $\mathrm{MgOCl}_{2}$ liposomes, $\mathrm{MgOCl}_{2}$ immunoliposomes, and $3 \mathrm{mM} \mathrm{MgOCl}{ }_{2}$.

4. In a previous identified LB agar plate add $100 \mu \mathrm{l}$ of the corresponding well mixed solution prepared on step 2 and 3 at time 0 hours, place the vials in a shaking incubator at physiological conditions. Place the plates in the incubator at the same conditions (do not shake the plates).

5. After one hour of incubation, remove the vials from the incubator and repeat step.

6. Place the vials in the shaking incubator at physiological conditions. Place the plates in the incubator at the same conditions (do not shake the plates).

7. After two hours of incubation, remove the vials from the incubator and repeat step

8. Let the plate incubate for a period of 8 hours, in the incubator. The colonies should be visible at this time, and count the colonies formed. 


\section{Colony Growth assay pictures, Test 2}

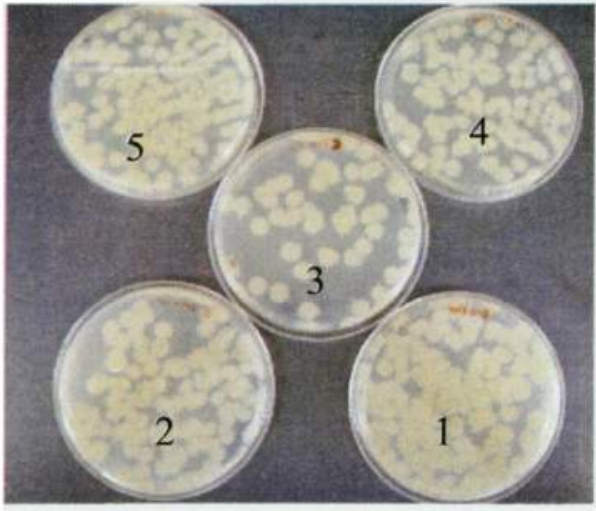

(A)

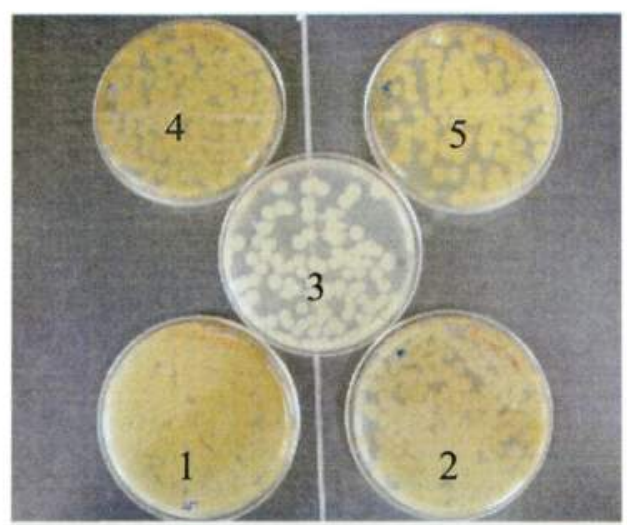

(B)

Figure 23. Bacillus thuringiensis colony growth assay (A) Colony growth assay for B. thuringiensis after 1 hour treatment with $\mathrm{MgOCl}_{2}$ solutions, incubated overnight, where (1), is $B$. thuringiensis in HEPES, (2), is B. thuringiensis in Empty liposomes, (3), B. thuringiensis in $\mathrm{MgOCl}_{2}$ immunoliposomes, (4) is $B$. thuringiensis in $\mathrm{MgOCl}_{2}$ liposomes, and (5), is B. thuringiensis in $3 \mathrm{mM}$ $\mathrm{MgOCl}_{2}$ solution (B) Colony growth assay for $\mathrm{B}$. thuringiensis after two hours of treatment with $\mathrm{MgOCl}_{2}$ solutions, incubated overnight. Observe the reduction of CFU's in plate number 3.

\section{Colony Growth Assay Pictures, Test 3}

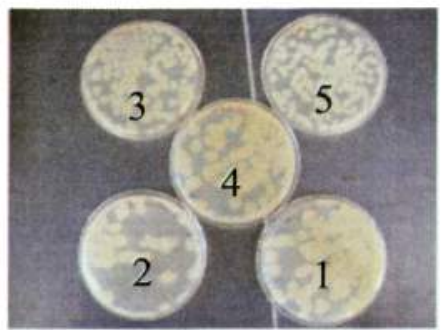

(A)

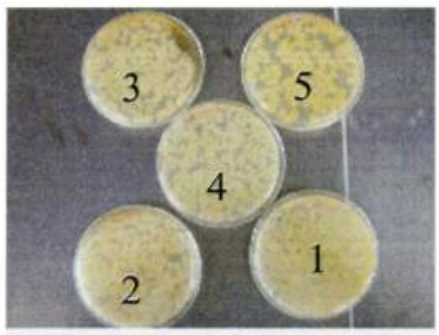

(B)

Figure 24. Bacillus thuringiensis colony growth assay (A) Colony growth assay for $B$. thuringiensis after 1 hour treatment with $\mathrm{MgOCl}_{2}$ solutions, incubated overnight, where (1), is $B$. thuringiensis in HEPES, (2), is B. thuringiensis in Empty liposomes, (3), B. thuringiensis in $\mathrm{MgOCl}_{2}$ immunoliposomes, (4) is $B$. thuringiensis in $\mathrm{MgOCl}_{2}$ liposomes, and (5), is $B$. thuringiensis in $3 \mathrm{mM}$ $\mathrm{MgOCl}_{2}$ solution (B) Colony growth assay for $B$. thuringiensis after two hours of treatment with $\mathrm{MgOCl}_{2}$ solutions, incubated overnight. 
Appendix H. Live/Dead assay protocol (adapted from Invitrogen protocol)

1. Concentrate $10 \mathrm{ml}$ of the overnight culture in a centrifuge at $10,000 \mathrm{X} \mathrm{g}$ for a period of 15 minutes.

2. Remove the supernatant and resuspend the pellet in $10 \mathrm{ml}$ of $.85 \%$ of $\mathrm{NaCl}$

3. Separate the resuspended $10 \mathrm{ml}$ of cell solution into 5 flasks

4. Centrifuge the solution at $10,000 \mathrm{Xg}$ for a period of 15 minutes.

5. Remove the supernatant of each vial and resuspend the pellet in $1 \mathrm{ml}$ of HEPES, empty liposomes, $\mathrm{MgOCl}_{2}$ liposomes, $\mathrm{MgOCl}_{2}$ - immunoliposomes and $3 \mathrm{mM}$ $\mathrm{MgOCl}_{2}$ respectively

6. Adjust the cell concentrations to $1 \times 10^{8}$ cells $/ \mathrm{ml}$

7. Prepare a mixture of $10 \mu \mathrm{l}$ of component A with $10 \mu \mathrm{l}$ of component B

8. Add $3 \mu \mathrm{l}$ of the dye mixture for each $\mathrm{ml}$ of bacterial suspension

9. Mix thoroughly and incubate in the dark for 15 minutes

10. Trap $5 \mu \mathrm{l}$ of the stained solution between a slide and a $18 \mathrm{~mm}$ square cover slip 11. Observe the bacteria under the microscope using a $40 \mathrm{X}$ lens with the appropriate filter in order to see the stained bacteria.

Appendix I. Two paired t-test results for Bacillus thuringiensis, colony growth assay.

Bacillus thuringiensis incubated with HEPES buffer reduction percentages $\left(\mu_{1}\right)$ compared to the reduction percentages of Bacillus thuringiensis incubated with Empty Liposomes $\left(\mu_{2}\right)$

\begin{tabular}{|c|c|c|c|c|}
\hline \multicolumn{3}{|c|}{ Two paired t-test for $\mu_{1} \neq \mu_{2} \mathrm{H}_{0}=\mu_{1}=\mu_{2}$} & & \\
\hline & & \multicolumn{3}{|c|}{ t-Test: Paired Two Sample for Means } \\
\hline$\mu_{1}$ & $\mu_{2}$ & & Variable 1 & Variable 2 \\
\hline 0 & 36.2 & Mean & 0 & 47.0502978 \\
\hline 0 & 30.3 & Variance & 0 & 1660.05595 \\
\hline 0 & 78 & Observations & 8 & 8 \\
\hline 0 & 31.9 & Pearson Correlation & \#DIV/0! & \\
\hline 0 & 100 & $\begin{array}{l}\text { Hypothesized Mean } \\
\text { Difference }\end{array}$ & 0 & \\
\hline 0 & 0 & Df & 7 & \\
\hline 0 & 0 & T Stat & -3.266224 & \\
\hline \multirow[t]{4}{*}{0} & 100 & $\mathrm{P}(\mathrm{T}<=t)$ one-tail & 0.0068729 & \\
\hline & & T Critical one-tail & 1.8945775 & \\
\hline & & $\mathrm{P}(\mathrm{T}<=\mathrm{t})$ two-tail & 0.0137458 & \\
\hline & & T Critical two-tail & 2.3646226 & \\
\hline
\end{tabular}

Table I-1 B. thuringiensis incubated with HEPES buffer CGA 
Bacillus thuringiensis incubated with HEPES buffer reduction percentages $\left(\mu_{1}\right)$ compared to the reduction percentages of Bacillus thuringiensis incubated with $\mathrm{MgOCl}_{2}$ liposomes $\left(\mu_{3}\right)$.

\begin{tabular}{|c|c|c|c|c|}
\hline \multicolumn{3}{|c|}{ Two paired t-test for $\mu_{1} \neq \mu_{3} \mathrm{H}_{0}=\mu_{1}=\mu_{3}$} & & \\
\hline \multirow[b]{2}{*}{$\mu_{1}$} & \multirow[b]{2}{*}{$\mu_{3}$} & \multicolumn{3}{|c|}{ t-Test: Paired Two Sample for Means } \\
\hline & & & Variable 1 & Variable 2 \\
\hline 0 & 57.8 & Mean & 0 & 48.9429568 \\
\hline 0 & 55.06 & Variance & 0 & 305.819196 \\
\hline 0 & 80 & Observations & 8 & 8 \\
\hline 0 & 38.0 & Pearson Correlation & \#DIV/0! & \\
\hline 0 & 26.5 & $\begin{array}{l}\text { Hypothesized Mean } \\
\text { Difference }\end{array}$ & 0 & \\
\hline 0 & 60.3 & Df & 7 & \\
\hline 0 & 40 & t Stat & -7.915946 & \\
\hline \multirow[t]{4}{*}{0} & 33.8 & $\mathrm{P}(\mathrm{T}<=\mathrm{t})$ one-tail & $4.875 \mathrm{E}-05$ & \\
\hline & & t Critical one-tail & 1.8945775 & \\
\hline & & $\mathrm{P}(\mathrm{T}<=\mathrm{t})$ two-tail & $9.75 \mathrm{E}-05$ & \\
\hline & & t Critical two-tail & 2.3646226 & \\
\hline
\end{tabular}

Bacillus thuringiensis incubated with HEPES buffer reduction percentages $\left(\mu_{1}\right)$ compared to the reduction percentages of Bacillus thuringiensis incubated with $\mathrm{MgOCl}_{2}$ immunoliposomes $\left(\mu_{4}\right)$.

\begin{tabular}{|c|c|c|c|c|}
\hline \multicolumn{2}{|c|}{$\begin{array}{l}\text { Two paired t-test for } \\
\mu_{1} \neq \mu_{4} \mathrm{H}_{0}=\mu_{1}=\mu_{4}\end{array}$} & \multicolumn{3}{|c|}{ t-Test: Paired Two Sample for Means } \\
\hline$\mu_{1}$ & $\mu_{4}$ & Mean & Variable 1 & Variable 2 \\
\hline 0 & 0 & Variance & 0 & 21.1295646 \\
\hline 0 & 20.8 & Observations & 0 & 626.813714 \\
\hline 0 & 52.3 & $\begin{array}{c}\text { Pearson } \\
\text { Correlation }\end{array}$ & 8 & 8 \\
\hline 0 & 0 & $\begin{array}{c}\text { Hypothesized } \\
\text { Mean Difference }\end{array}$ & \#DIV/0! & \\
\hline 0 & 0 & Df & 0 & \\
\hline 0 & 57.7 & T Stat & 7 & \\
\hline 0 & 38.3 & $\mathrm{P}(\mathrm{T}<=\mathrm{t})$ one-tail & -2.387076 & \\
\hline \multirow[t]{4}{*}{0} & 0 & T Critical one-tail & 0.0241881 & \\
\hline & & $\mathrm{P}(\mathrm{T}<=\mathrm{t})$ two-tail & 1.8945775 & \\
\hline & & T Critical two-tail & 0.0483762 & \\
\hline & & & 2.3646226 & \\
\hline
\end{tabular}


Bacillus thuringiensis incubated with empty liposomes reduction percentages $\left(\mu_{2}\right)$ compared to the reduction percentages of Bacillus thuringiensis incubated with $\mathrm{MgOCl}_{2}$ liposomes $\left(\mu_{3}\right)$.

\begin{tabular}{|c|c|c|c|c|}
\hline \multicolumn{2}{|c|}{$\begin{array}{c}\text { wwo paired } \\
\mathrm{t} \text {-test }\end{array}$} & \multicolumn{3}{|c|}{$\mathrm{t}$-Test: Paired Two Sample for Means, for $\mu_{2} \neq \mu_{3}$} \\
\hline$\mu_{2}$ & $\mu_{3}$ & & $\mu_{2}=\mu_{3}$ \\
\hline 36.2 & 57.8 & Mean & 47.050298 & 48.9429568 \\
\hline 30.3 & 55.06 & Variance & 1660.0559 & 305.819196 \\
\hline 78 & 80 & Observations & 8 & 8 \\
\hline 31.9 & 38.0 & Pearson correlation & -0.235225 & \\
\hline 100 & 26.5 & $\begin{array}{c}\text { Hypothesized Mean } \\
\text { Difference }\end{array}$ & 0 & \\
\hline 0 & 60.3 & Df & 7 & \\
\hline 0 & 40 & t Stat & -0.111597 & \\
\hline 100 & 33.8 & $\mathrm{P}(\mathrm{T}<=\mathrm{t})$ one-tail & 0.4571378 & \\
\hline & & $\mathrm{t}$ Critical one-tail & 1.8945775 & \\
\hline & & $\mathrm{P}(\mathrm{T}<=\mathrm{t})$ two-tail & 0.9142757 & \\
\hline & & $\mathrm{t}$ Critical two-tail & 2.3646226 & \\
\hline
\end{tabular}

Bacillus thuringiensis incubated with empty liposomes reduction percentages $\left(\mu_{2}\right)$ compared to the reduction percentages of Bacillus thuringiensis incubated with $\mathrm{MgOCl}_{2}$ immunoliposomes $\left(\mu_{4}\right)$

\begin{tabular}{|l|l|l|l|l|}
\hline \multicolumn{2}{|r|}{$\begin{array}{r}\text { Two paired } \\
\text { t-test }\end{array}$} & for $\mu_{4} \neq \mu_{2} \mathrm{H}_{0}=\mu_{4}=\mu_{2}$ & Variable I & Variable 2 \\
\hline$\mu_{2}$ & $\mu_{4}$ & Mean & 47.050298 & 21.1295646 \\
\hline 36.2 & 0 & Variance & 1660.0559 & 626.813714 \\
\hline 30.3 & 20.8 & Observations & 8 & 8 \\
\hline 78 & 52.3 & Pearson Correlation & -0.453836 & \\
\hline 31.9 & 0 & $\begin{array}{l}\text { Hypothesized Mean } \\
\text { Difference }\end{array}$ & 0 & \\
\hline 100 & 0 & Df & 7 & \\
\hline 0 & 57.7 & t Stat & 1.2934604 & \\
\hline 0 & 38.3 & P(T<=t) one-tail & 0.1184481 & \\
\hline 100 & 0 & t Critical one-tail & 1.8945775 & \\
\hline & & P(T<=t) two-tail & 0.2368962 & \\
\hline & & t Critical two-tail & 2.3646226 & \\
\hline
\end{tabular}


Bacillus thuringiensis incubated with empty liposomes reduction percentages $\left(\mu_{2}\right)$ compared to the reduction percentages of Bacillus thuringiensis incubated with $3 \mathrm{mM}$ $\mathrm{MgOCl}_{2}\left(\mu_{5}\right)$.

\begin{tabular}{|l|l|l|l|l|}
\hline \multicolumn{3}{|l|}{$\begin{array}{l}\text { Two paired t- } \\
\text { test for } \mu_{2} \neq \mu_{5} \\
\mathrm{H}_{0}=\mu_{2}=\mu_{5}\end{array}$} & t-Test: Paired Two Sample for Means \\
\hline$\mu_{2}$ & $\mu_{5}$ & & Variable 1 & Variable 2 \\
\hline 36.2 & 0 & Mean & 47.050298 & 13.5520833 \\
\hline 30.3 & 0 & Variance & 1660.0559 & 356.914559 \\
\hline 78 & 32 & Observations & 8 & 8 \\
\hline 31.9 & 0 & Pearson Correlation & -0.483473 & \\
\hline 100 & 0 & $\begin{array}{l}\text { Hypothesized Mean } \\
\text { Difference }\end{array}$ & 0 & \\
\hline 0 & 41.7 & Df & 7 & \\
\hline 0 & 34.8 & t Stat & 1.8030696 & \\
\hline 100 & 0 & P(T<=t) one-tail & 0.0571847 & \\
\hline & & t Critical one-tail & 1.8945775 & \\
\hline & & P(T<=t) two-tail & 0.1143694 & \\
\hline & & t Critical two-tail & 2.3646226 & \\
\hline
\end{tabular}


Appendix J. Bacillus thuringiensis, live/dead assay t-test: paired two sample for means

Bacillus thuringiensis, incubated with HEPES at time 1 hour $(\mu 1,1)$ compared to $B$. thuringiensis incubated with empty liposomes at 1 hour of incubation $(\mu 2,1)$, where $\mu_{1} \neq \mu_{2} \mathrm{H}_{0}=\mu_{1,1}=\mu_{2,1}$

\begin{tabular}{|r|r|c|r|r|}
\hline $\boldsymbol{\mu}_{\mathbf{1}, \mathbf{1}}$ & \multicolumn{1}{|c|}{$\boldsymbol{\mu}_{\mathbf{2 , 1}}$} & & \multicolumn{1}{|c|}{ Variable 1 } & \multicolumn{1}{c|}{ Variable 2 } \\
\hline 8.7 & 7.7 & Mean & 14.9 & 19.16667 \\
\hline 10.7 & 18.7 & Variance & 82.12 & 137.0533 \\
\hline 25.3 & 31.1 & Observations & 3 & 3 \\
\hline & & Pearson Correlation & 0.929222 & \\
\hline & & $\begin{array}{c}\text { Hypothesized Mean } \\
\text { Difference }\end{array}$ & 0 & \\
\hline & & Df & 2 & \\
\hline & & t Stat & -1.57509 & \\
\hline & & $\mathrm{P}(\mathrm{T}<=$ t) one-tail & 0.127957 & \\
\hline & & t Critical one-tail & 2.919987 & \\
\hline & & $\mathrm{P}(\mathrm{T}<=$ t) two-tail & 0.255915 & \\
\hline & & $\mathrm{t}$ Critical two-tail & 4.302656 & \\
\hline
\end{tabular}

Bacillus thuringiensis, incubated with HEPES at time 1 hour $(\mu 1,1)$ compared to $B$. thuringiensis incubated with $\mathrm{MgOCl}_{2}$ liposomes at 1 hour of incubation $(\mu 3,1)$, where $\mu_{1} \neq \mu_{3} \mathrm{H}_{0}=\mu_{1,1}=\mu_{3,1}$

\begin{tabular}{|r|r|c|r|r|}
\hline \multicolumn{1}{|c|}{$\boldsymbol{\mu}_{1,1}$} & $\boldsymbol{\mu}_{3,1}$ & & \multicolumn{1}{|c|}{ Variable 1 } & \multicolumn{1}{|c|}{ Variable 2 } \\
\hline 8.7 & 20.0 & Mean & 14.9 & 31.6667 \\
\hline 10.7 & 32.0 & Variance & 82.12 & 132.333 \\
\hline 25.3 & 43.0 & Observations & 3 & 3 \\
\hline & & Pearson Correlation & 0.90555 & \\
\hline & & $\begin{array}{c}\text { Hypothesized Mean } \\
\text { Difference }\end{array}$ & 0 & \\
\hline & & Df & 2 & \\
\hline & & t Stat & -5.7337 & \\
\hline & & $\mathrm{P}(\mathrm{T}<=$ t) one-tail & 0.01455 & \\
\hline & & t Critical one-tail & 2.91999 & \\
\hline & & $\mathrm{P}(\mathrm{T}<=\mathrm{t})$ two-tail & 0.0291 & \\
\hline & & $\mathrm{t}$ Critical two-tail & 4.30266 & \\
\hline
\end{tabular}


Bacillus thuringiensis, incubated with HEPES at time 1 hour $(\mu 1,1)$ compared to $B$. thuringiensis incubated with $\mathrm{MgOCl}_{2}$ immunoliposomes at 1 hour of incubation $(\mu 4,1)$, where $\mu_{1} \neq \mu_{4} \mathrm{H}_{0}=\mu_{1,1}=\mu_{4,1}$

\begin{tabular}{|r|r|c|r|r|}
\hline $\boldsymbol{\mu}_{1,1}$ & \multicolumn{1}{|c|}{$\boldsymbol{\mu}_{\mathbf{4}, \mathbf{1}}$} & Variable 1 & \multicolumn{1}{c|}{ Variable 2 } \\
\hline 8.7 & 22.0 & Mean & 14.9 & 29.6667 \\
\hline 10.7 & 27.0 & Variance & 82.12 & 86.3333 \\
\hline 25.3 & 40.0 & Observations & 3 & 3 \\
\hline & & Pearson Correlation & 0.98693 & \\
\hline & & $\begin{array}{c}\text { Hypothesized Mean } \\
\text { Difference }\end{array}$ & 0 & \\
\hline & & Df & 2 & \\
\hline & & t Stat & -17.038 & \\
\hline & & P(T<=t) one-tail & 0.00171 & \\
\hline & & t Critical one-tail & 2.91999 & \\
\hline & & P(T<=t) two-tail & 0.00343 & \\
\hline & & t Critical two-tail & 4.30266 & \\
\hline
\end{tabular}

Bacillus thuringiensis, incubated with HEPES at time 1 hour $(\mu 1,1)$ compared to $B$. thuringiensis incubated with $3 \mathrm{mM} \mathrm{MgOCl} l_{2}$ at 1 hour of incubation $(\mu 5,1)$, where $\mu_{1} \neq \mu_{5}$ $\mathrm{H}_{0}=\mu_{1,1}=\mu_{5,1}$

\begin{tabular}{|r|r|c|r|r|}
\hline \multicolumn{1}{|c|}{$\boldsymbol{\mu}_{\mathbf{1}, \mathbf{1}}$} & $\boldsymbol{\mu}_{\mathbf{5 , 1}}$ & & \multicolumn{1}{|c|}{ Variable 1 } & \multicolumn{1}{|c|}{ Variable 2 } \\
\hline 8.7 & 13.0 & Mean & 14.9 & 26.3333 \\
\hline 10.7 & 30.0 & Variance & 82.12 & 142.333 \\
\hline 25.3 & 36.0 & Observations & 3 & 3 \\
\hline & & Pearson Correlation & 0.77604 & \\
\hline & & $\begin{array}{c}\text { Hypothesized Mean } \\
\text { Difference }\end{array}$ & 0 & \\
\hline & & Df & 2 & \\
\hline & & t Stat & -2.631 & \\
\hline & & $\mathrm{P}(\mathrm{T}<=$ t) one-tail & 0.05959 & \\
\hline & & t Critical one-tail & 2.91999 & \\
\hline & & $\mathrm{P}(\mathrm{T}<=$ t) two-tail & 0.11918 & \\
\hline & & $\mathrm{t}$ Critical two-tail & 4.30266 & \\
\hline
\end{tabular}


Bacillus thuringiensis, incubated with empty liposomes at time 0 hours $(\mu 2,0)$ compared to $B$. thuringiensis incubated with empty liposomes at 1 hour of incubation $(\mu 2,1)$, where $\mu_{2,0} \neq \mu_{2,1} \mathrm{H}_{0}=\mu_{2,0}=\mu_{2,1}$

\begin{tabular}{|l|l|l|l|l|}
\hline & & \multicolumn{3}{|c|}{ t-Test: Paired Two Sample for Means } \\
\hline $\boldsymbol{\mu}_{\mathbf{2}, \mathbf{0}}$ & $\boldsymbol{\mu}_{\mathbf{2 , 1}}$ & & Variable 1 & Variable 2 \\
\hline 4.3 & 7.7 & Mean & 14.6666667 & 19.14815 \\
\hline 20.7 & 18.7 & Variance & 80.7777778 & 137.5844 \\
\hline 19 & 31.1 & Observations & 3 & 3 \\
\hline & & Pearson Correlation & 0.79486676 & \\
\hline & & $\begin{array}{l}\text { Hypothesized Mean } \\
\text { Difference }\end{array}$ & 0 & \\
\hline & & Df & 2 & \\
\hline & & T Stat & -1.089383 & \\
\hline & & P(T<=t) one-tail & 0.19487609 & \\
\hline & & T Critical one-tail & 2.91998731 & \\
\hline & & P(T<=t) two-tail & 0.38975219 & \\
\hline & & T Critical two-tail & 4.30265573 & \\
\hline
\end{tabular}

Bacillus thuringiensis, incubated with empty liposomes at time 1 hours $(\mu 2,1)$ compared to $B$. thuringiensis incubated with $\mathrm{MgOCl}_{2}$ liposomes at 1 hour of incubation $(\mu 3,1)$, where $\mu_{2} \neq \mu_{3} \mathrm{H}_{0}=\mu_{2,1}=\mu_{3,1}$

\begin{tabular}{|r|r|c|r|r|}
\hline $\boldsymbol{\mu}_{\mathbf{2 , 1}}$ & $\boldsymbol{\mu}_{3,1}$ & & Variable 1 & Variable 2 \\
\hline 7.7 & 20.0 & Mean & 19.1667 & 31.6667 \\
\hline 18.7 & 32.0 & Variance & 137.053 & 132.333 \\
\hline 31.1 & 43.0 & Observations & 3 & 3 \\
\hline & & Pearson Correlation & 0.99822 & \\
\hline & & $\begin{array}{c}\text { Hypothesized Mean } \\
\text { Difference }\end{array}$ & 0 & \\
\hline & & Df & 2 & \\
\hline & & t Stat & -30.024 & \\
\hline & & P(T<=t) one-tail & 0.00055 & \\
\hline & & t Critical one-tail & 2.91999 & \\
\hline & & $\mathrm{P}(\mathrm{T}<=\mathrm{t})$ two-tail & 0.00111 & \\
\hline & & $\mathrm{t}$ Critical two-tail & 4.30266 & \\
\hline
\end{tabular}


Bacillus thuringiensis, incubated with empty liposomes at time 1 hours $(\mu 2,1)$ compared to $B$. thuringiensis incubated with $\mathrm{MgOCl}_{2}$ immunoliposomes at 1 hour of incubation $(\mu 4,1)$, where $\mu_{2} \neq \mu_{4} \mathrm{H}_{0}=\mu_{2,1}=\mu_{4,1}$

\begin{tabular}{|r|r|c|r|r|}
\hline $\boldsymbol{\mu}_{\mathbf{2}, \mathbf{1}}$ & $\boldsymbol{\mu}_{\mathbf{4}, \mathbf{1}}$ & & Variable 1 & \multicolumn{1}{c|}{ Variable 2 } \\
\hline 7.7 & 22.0 & Mean & 19.1667 & 29.6667 \\
\hline 18.7 & 27.0 & Variance & 137.053 & 86.3333 \\
\hline 31.1 & 40.0 & Observations & 3 & 3 \\
\hline & & Pearson Correlation & 0.97662 & \\
\hline & & $\begin{array}{c}\text { Hypothesized Mean } \\
\text { Difference }\end{array}$ & 0 & \\
\hline & & Df & 2 & \\
\hline & & t Stat & -5.5035 & \\
\hline & & P(T<=t) one-tail & 0.01573 & \\
\hline & & t Critical one-tail & 2.91999 & \\
\hline & & $\mathrm{P}(\mathrm{T}<=$ t) two-tail & 0.03147 & \\
\hline & & $\mathrm{t}$ Critical two-tail & 4.30266 & \\
\hline
\end{tabular}

Bacillus thuringiensis, incubated with empty liposomes at timel hour $(\mu 2,1)$ compared to B. thuringiensis incubated with $3 \mathrm{mM} \mathrm{MgOCl}_{2}$ at 1 hour of incubation $(\mu 5,1)$, where $\mu_{2} \neq \mu_{5} \mathrm{H}_{0}=\mu_{2}=\mu_{5}$

\begin{tabular}{|r|r|c|r|r|}
\hline \multicolumn{1}{|c|}{$\boldsymbol{\mu}_{\mathbf{2 , 1}}$} & $\boldsymbol{\mu}_{\mathbf{5}, \mathbf{1}}$ & & \multicolumn{1}{|c|}{ Variable 1 } & \multicolumn{1}{|c|}{ Variable 2 } \\
\hline 7.7 & 13.0 & Mean & 19.1667 & 26.3333 \\
\hline 18.7 & 30.0 & Variance & 137.053 & 142.333 \\
\hline 31.1 & 36.0 & Observations & 3 & 3 \\
\hline & & Pearson Correlation & 0.95416 & \\
\hline & & $\begin{array}{c}\text { Hypothesized Mean } \\
\text { Difference }\end{array}$ & 0 & \\
\hline & & Df & 2 & \\
\hline & & t Stat & -3.4623 & \\
\hline & & $\mathrm{P}(\mathrm{T}<=$ t) one-tail & 0.03712 & \\
\hline & & $\mathrm{t}$ Critical one-tail & 2.91999 & \\
\hline & & $\mathrm{P}(\mathrm{T}<=$ t) two-tail & 0.07425 & \\
\hline & & $\mathrm{t}$ Critical two-tail & 4.30266 & \\
\hline
\end{tabular}


Appendix K. B. subtilis, live/dead assay t-test: paired two sample for means

B. subtilis incubated with HEPES at time 1 hours $(\mu 1,1)$ compared to $B$. subtilis incubated with Empty liposomes at 1 hour of incubation $(\mu 4,1)$, where $\mu_{1} \neq \mu_{2}$ $\mathrm{H}_{0}=\mu_{1,1}=\mu_{2,1}$.

\begin{tabular}{|c|c|c|c|c|}
\hline $\boldsymbol{\mu}_{1,1}$ & $\boldsymbol{\mu}_{2,1}$ & & Variable 1 & Variable 2 \\
\hline 20.0 & 28.9 & Mean & 23 & 23.2963 \\
\hline 23.0 & 18.0 & Variance & 9 & 29.70782 \\
\hline 26.0 & 23.0 & Observations & 3 & 3 \\
\hline & & Pearson Correlation & -0.54022 & \\
\hline & & $\begin{array}{c}\text { Hypothesized Mean } \\
\text { Difference }\end{array}$ & 0 & \\
\hline & & Df & 2 & \\
\hline & & t Stat & -0.06835 & \\
\hline & & P(T<=t) one-tail & 0.475862 & \\
\hline & & t Critical one-tail & 2.919987 & \\
\hline & & $\mathrm{P}(\mathrm{T}<=$ t) two-tail & 0.951725 & \\
\hline & & $\mathrm{t}$ Critical two-tail & 4.302656 & \\
\hline
\end{tabular}

B. subtilis incubated with HEPES at time 1 hours $(\mu 1,1)$ compared to B. subtilis incubated with $\mathrm{MgOCl}_{2}$ at 1 hour of incubation $(\mu 3,1)$, where $\mu_{1} \neq \mu_{3} \mathrm{H}_{0}=\mu_{1,1}=\mu_{3,1}$.

\begin{tabular}{|c|c|c|c|c|}
\hline $\boldsymbol{\mu}_{\mathbf{1}, 1}$ & $\boldsymbol{\mu}_{3,1}$ & & Variable 1 & Variable 2 \\
\hline 20.0 & 38.0 & Mean & 23 & 45.57881 \\
\hline 23.0 & 45.7 & Variance & 9 & 56.26863 \\
\hline 26.0 & 53.0 & Observations & 3 & 3 \\
\hline & & Pearson Correlation & 0.999834 & \\
\hline & & $\begin{array}{c}\text { Hypothesized Mean } \\
\text { Difference }\end{array}$ & 0 & \\
\hline & & Df & 2 & \\
\hline & & t Stat & -8.68659 & \\
\hline & & P(T<=t) one-tail & 0.006497 & \\
\hline & & t Critical one-tail & 2.919987 & \\
\hline & & P(T<=t) two-tail & 0.012995 & \\
\hline & & t Critical two-tail & 4.302656 & \\
\hline
\end{tabular}


B. subtilis incubated with HEPES at time 1 hours $(\mu 1,1)$ compared to B. subtilis incubated with $\mathrm{MgOCl}_{2}$ immunoliposomes at 1 hour of incubation $(\mu 4,1)$, where $\mu_{1} \neq \mu_{4}$ $\mathrm{H}_{0}=\mu_{1,1}=\mu_{4,1}$.

\begin{tabular}{|c|c|c|c|c|}
\hline $\boldsymbol{\mu}_{1,1}$ & $\boldsymbol{\mu}_{4,1}$ & & Variable 1 & Variable 2 \\
\hline 20.0 & 37.5 & Mean & 23 & 34.42557 \\
\hline 23.0 & 25.0 & Variance & 9 & 69.31516 \\
\hline 26.0 & 40.8 & Observations & 3 & 3 \\
\hline & & Pearson Correlation & 0.196785 & \\
\hline & & $\begin{array}{c}\text { Hypothesized Mean } \\
\text { Difference }\end{array}$ & 0 & \\
\hline & & Df & 2 & \\
\hline & & T Stat & -2.39133 & \\
\hline & & P(T<=t) one-tail & 0.069628 & \\
\hline & & t Critical one-tail & 2.919987 & \\
\hline & & P(T<=t) two-tail & 0.139255 & \\
\hline & & t Critical two-tail & 4.302656 & \\
\hline
\end{tabular}

B. subtilis incubated with empty liposomes at time 1 hours $(\mu 2,1)$ compared to B. subtilis incubated with $\mathrm{MgOCl}_{2}$ liposomes at 1 hour of incubation $(\mu 3,1)$, where $\mu_{2} \neq \mu_{3}$ $\mathrm{H}_{0}=\mu_{2,1}=\mu_{3,1}$.

\begin{tabular}{|c|c|c|c|c|}
\hline $\boldsymbol{\mu}_{\mathbf{2}, \mathbf{1}}$ & $\boldsymbol{\mu}_{\mathbf{3 , 1}}$ & & Variable 1 & Variable 2 \\
\hline 28.9 & 38 & Mean & 23.2963 & 45.57881 \\
\hline 18.0 & 45.7 & Variance & 29.70782 & 56.26863 \\
\hline 23.0 & 53.0 & Observations & 3 & 3 \\
\hline & & Pearson Correlation & -0.55544 & \\
\hline & & $\begin{array}{c}\text { Hypothesized Mean } \\
\text { Difference }\end{array}$ & 0 & \\
\hline & & Df & 2 & \\
\hline & & T Stat & -3.36694 & \\
\hline & & P(T<=t) one-tail & 0.039014 & \\
\hline & & t Critical one-tail & 2.919987 & \\
\hline & & P(T<=t) two-tail & 0.078028 & \\
\hline & & t Critical two-tail & 4.302656 & \\
\hline
\end{tabular}


B. subtilis incubated with empty liposomes at time 1 hours $(\mu 2,1)$ compared to B. subtilis incubated with $\mathrm{MgOCl}_{2}$ immunoliposomes at 1 hour of incubation $(\mu 4,1)$, where $\mu_{2} \neq \mu_{4}$ $\mathrm{H}_{0}=\mu_{2,1}=\mu_{4,1}$.

\begin{tabular}{|c|c|c|c|c|}
\hline $\boldsymbol{\mu}_{\mathbf{2}, \mathbf{1}}$ & $\boldsymbol{\mu}_{\mathbf{4 , 1}}$ & & Variable 1 & Variable 2 \\
\hline 28.9 & 37.5 & Mean & 23.2963 & 34.42557 \\
\hline 18.0 & 25.0 & Variance & 29.70782 & 69.31516 \\
\hline 23.0 & 40.8 & Observations & 3 & 3 \\
\hline & & Pearson Correlation & 0.718765 & \\
\hline & & $\begin{array}{c}\text { Hypothesized Mean } \\
\text { Difference }\end{array}$ & 0 & \\
\hline & & Df & 2 & \\
\hline & & T Stat & -3.31614 & \\
\hline & & $\mathrm{P}(\mathrm{T}<=\mathrm{t})$ one-tail & 0.040077 & \\
\hline & & $\mathrm{t}$ Critical one-tail & 2.919987 & \\
\hline & & $\mathrm{P}(\mathrm{T}<=\mathrm{t})$ two-tail & 0.080155 & \\
\hline & & $\mathrm{t}$ Critical two-tail & 4.302656 & \\
\hline
\end{tabular}

\section{Appendix L. Bacillus cereus, live/dead assay t-test: paired two sample for means}

B. cereus incubated with HEPES at time 1 hours $(\mu 1,1)$ compared to $B$. cereus incubated with empty liposomes at 1 hour of incubation $(\mu 2,1)$. where $\mu_{1} \neq \mu 2 \mathrm{H}_{0}=\mu_{1,1}=\mu_{2,1}$.

\begin{tabular}{|c|c|c|c|c|}
\hline $\boldsymbol{\mu}_{1,1}$ & $\boldsymbol{\mu}_{\mathbf{2}, \mathbf{1}}$ & & Variable 1 & Variable 2 \\
\hline 32.2 & 26.0 & Mean & 30.54333 & 30.66667 \\
\hline 28.5 & 34.0 & Variance & 3.597433 & 17.33333 \\
\hline 31.0 & 32.0 & Observations & 3 & 3 \\
\hline & & Pearson Correlation & -0.88182 & \\
\hline & & $\begin{array}{c}\text { Hypothesized Mean } \\
\text { Difference }\end{array}$ & 0 & \\
\hline & & Df & 2 & \\
\hline & & t Stat & -0.03618 & \\
\hline & & $\mathrm{P}(\mathrm{T}<=\mathrm{t})$ one-tail & 0.487212 & \\
\hline & & $\mathrm{t}$ Critical one-tail & 2.919987 & \\
\hline & & $\mathrm{P}(\mathrm{T}<=\mathrm{t})$ two-tail & 0.974424 & \\
\hline & & $\mathrm{t}$ Critical two-tail & 4.302656 & \\
\hline
\end{tabular}


B. cereus incubated with HEPES at time 1 hours $(\mu 1,1)$ compared to B. cereus incubated with $\mathrm{MgOCl}_{2}$ liposomes at 1 hour of incubation $(\mu 3,1)$, where $\mu_{1} \neq \mu_{3} \mathrm{H}_{0}=\mu_{1,1}=\mu_{3,1}$.

\begin{tabular}{|c|c|c|c|c|}
\hline $\boldsymbol{\mu}_{1,1}$ & $\boldsymbol{\mu}_{3,1}$ & & Variable 1 & Variable 2 \\
\hline 32.2 & 34.6 & Mean & 30.54333 & 30.43333 \\
\hline 28.5 & 27.7 & Variance & 3.597433 & 13.58173 \\
\hline 31.0 & 29.0 & Observations & 3 & 3 \\
\hline & & Pearson Correlation & 0.850641 & \\
\hline & & $\begin{array}{c}\text { Hypothesized Mean } \\
\text { Difference }\end{array}$ & 0 & \\
\hline & & Df & 2 & \\
\hline & & t Stat & 0.082858 & \\
\hline & & $\mathrm{P}(\mathrm{T}<=$ t) one-tail & 0.470755 & \\
\hline & & $\mathrm{t}$ Critical one-tail & 2.919987 & \\
\hline & & $\mathrm{P}(\mathrm{T}<=$ t) two-tail & 0.941511 & \\
\hline & & $\mathrm{t}$ Critical two-tail & 4.302656 & \\
\hline
\end{tabular}

B. cereus incubated with HEPES at time 0 hours $(\mu 1,1)$ compared to $B$. cereus incubated with $\mathrm{MgOCl}_{2}$ immunoliposomes at 1 hour of incubation $(\mu 4,1)$ where $\mu_{1} \neq \mu_{4} \mathrm{H}_{0}=\mu_{1,1}=\mu_{4,1}$.

\begin{tabular}{|c|c|c|c|c|}
\hline $\boldsymbol{\mu}_{1,1}$ & $\boldsymbol{\mu}_{4,1}$ & & Variable 1 & Variable 2 \\
\hline 32.2 & 38.0 & Mean & 30.54333 & 30.24667 \\
\hline 28.5 & 32.7 & Variance & 3.597433 & 85.66253 \\
\hline 31.0 & 20.0 & Observations & 3 & 3 \\
\hline & & Pearson Correlation & 0.077995 & \\
\hline & & $\begin{array}{c}\text { Hypothesized Mean } \\
\text { Difference }\end{array}$ & 0 & \\
\hline & & Df & 2 & \\
\hline & & t Stat & 0.055242 & \\
\hline & & P(T<=t) one-tail & 0.480484 & \\
\hline & & t Critical one-tail & 2.919987 & \\
\hline & & $\mathrm{P}(\mathrm{T}<=\mathrm{t})$ two-tail & 0.960968 & \\
\hline & & $\mathrm{t}$ Critical two-tail & 4.302656 & \\
\hline
\end{tabular}


B. cereus incubated with empty liposomes at time 1 hours $(\mu 2,1)$ compared to $B$. cereus incubated with $\mathrm{MgOCl}_{2}$ liposomes at 1 hour of incubation $(\mu 3,1)$ where $\mu_{2} \neq \mu_{3}$ $\mathrm{H}_{0}=\mu_{2,1}=\mu_{3,1}$.

\begin{tabular}{|c|c|c|c|c|}
\hline $\boldsymbol{\mu}_{2, \mathbf{1}}$ & $\boldsymbol{\mu}_{3, \mathbf{1}}$ & & Variable 1 & Variable 2 \\
\hline 26.0 & 34.6 & Mean & 30.66667 & 30.43333 \\
\hline 34.0 & 27.7 & Variance & 17.33333 & 13.58173 \\
\hline 32.0 & 29.0 & Observations & 3 & 3 \\
\hline & & Pearson Correlation & -0.99805 & \\
\hline & & $\begin{array}{c}\text { Hypothesized Mean } \\
\text { Difference }\end{array}$ & 0 & \\
\hline & & Df & 2 & \\
\hline & & t Stat & 0.051517 & \\
\hline & & P(T<-t) one-tail & 0.481798 & \\
\hline & & t Critical one-tail & 2.919987 & \\
\hline & & P(T<=t) two-tail & 0.963596 & \\
\hline & & t Critical two-tail & 4.302656 & \\
\hline
\end{tabular}

B. cereus incubated with empty liposomes at time 1 hours $(\mu 2,1)$ compared to B. cereus incubated with $\mathrm{MgOCl}_{2}$ immunoliposomes at 1 hour of incubation $(\mu 4,1)$, where $\mu_{2} \neq \mu_{4}$ $\mathrm{H}_{0}=\mu_{2,1}=\mu_{4,1}$.

\begin{tabular}{|c|c|c|c|c|}
\hline $\boldsymbol{\mu}_{\mathbf{2}, \mathbf{1}}$ & $\boldsymbol{\mu}_{4,1}$ & & Variable 1 & Variable 2 \\
\hline 26.0 & 38.0 & Mean & 30.66667 & 30.24667 \\
\hline 34.0 & 32.7 & Variance & 17.33333 & 85.66253 \\
\hline 32.0 & 20.0 & Observations & 3 & 3 \\
\hline & & Pearson Correlation & -0.53893 & \\
\hline & & $\begin{array}{c}\text { Hypothesized Mean } \\
\text { Difference }\end{array}$ & 0 & \\
\hline & & Df & 2 & \\
\hline & & t Stat & 0.060511 & \\
\hline & & P(T<=t) one-tail & 0.478626 & \\
\hline & & t Critical one-tail & 2.919987 & \\
\hline & & P(T<=t) two-tail & 0.957252 & \\
\hline & & t Critical two-tail & 4.302656 & \\
\hline
\end{tabular}




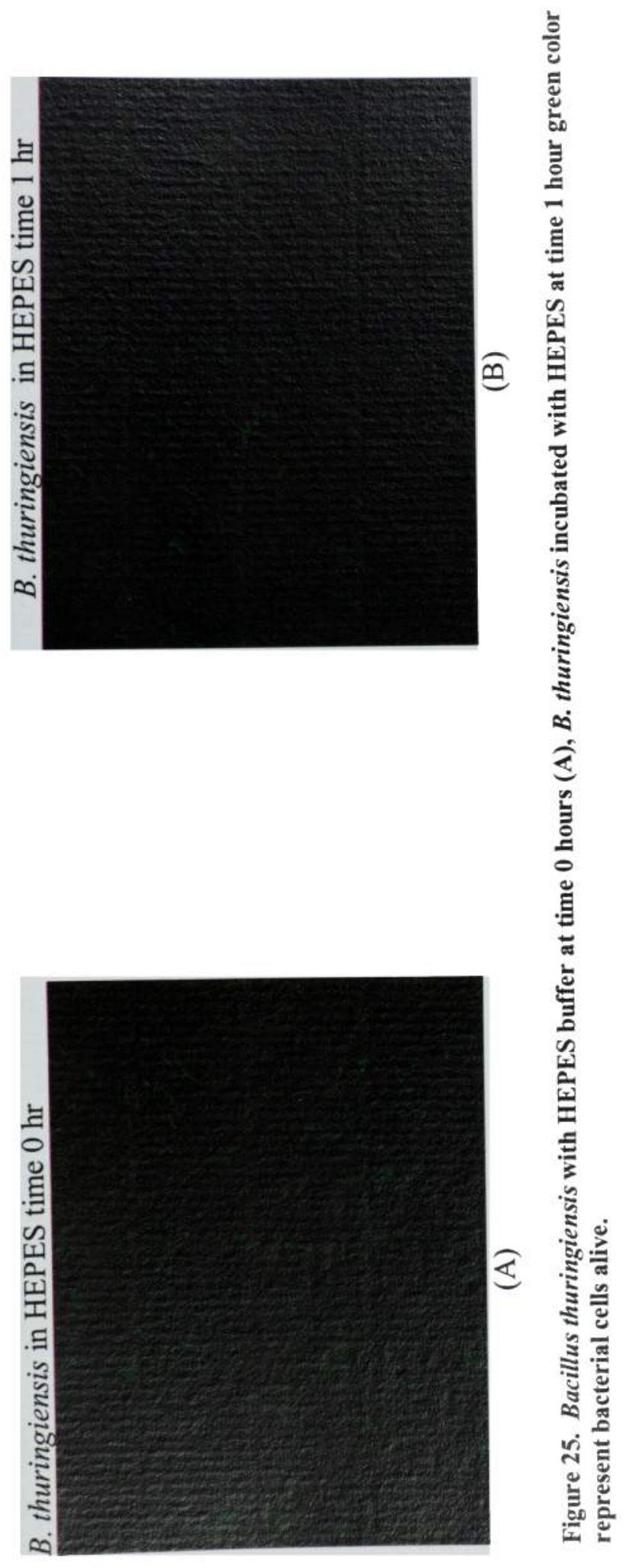




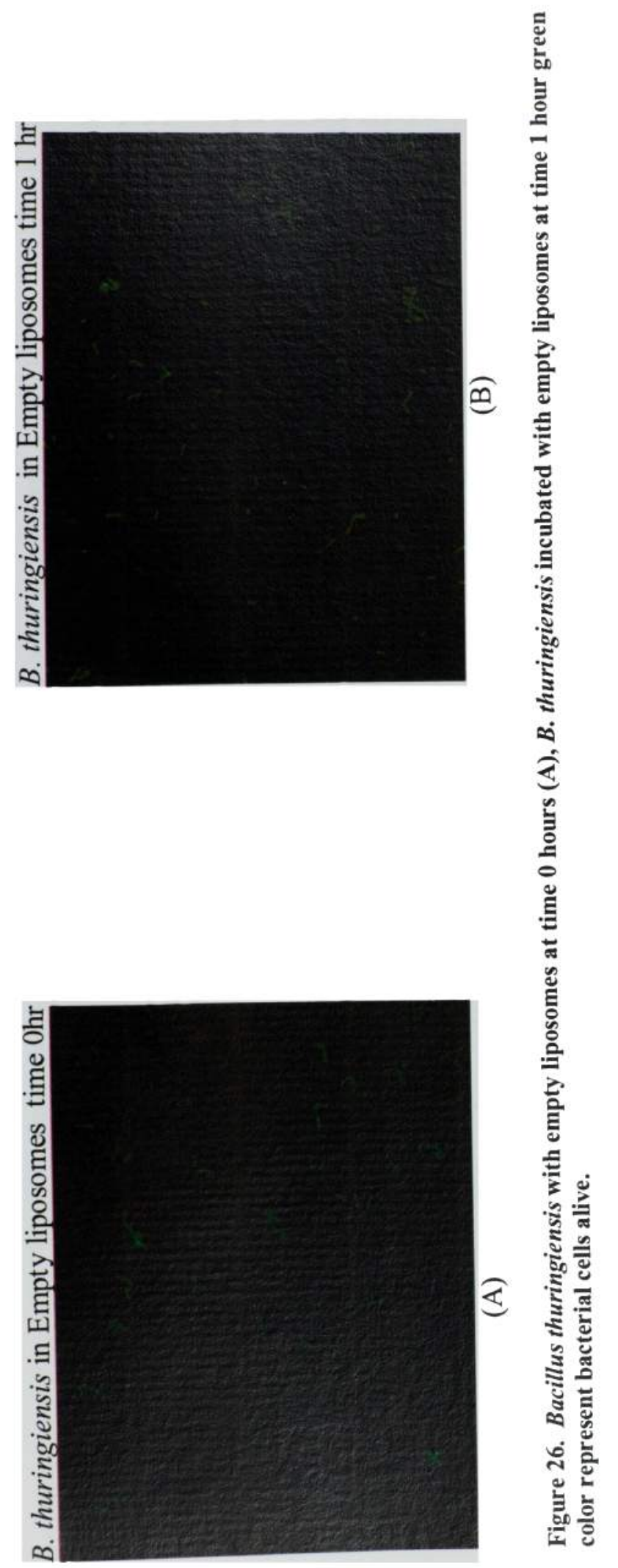



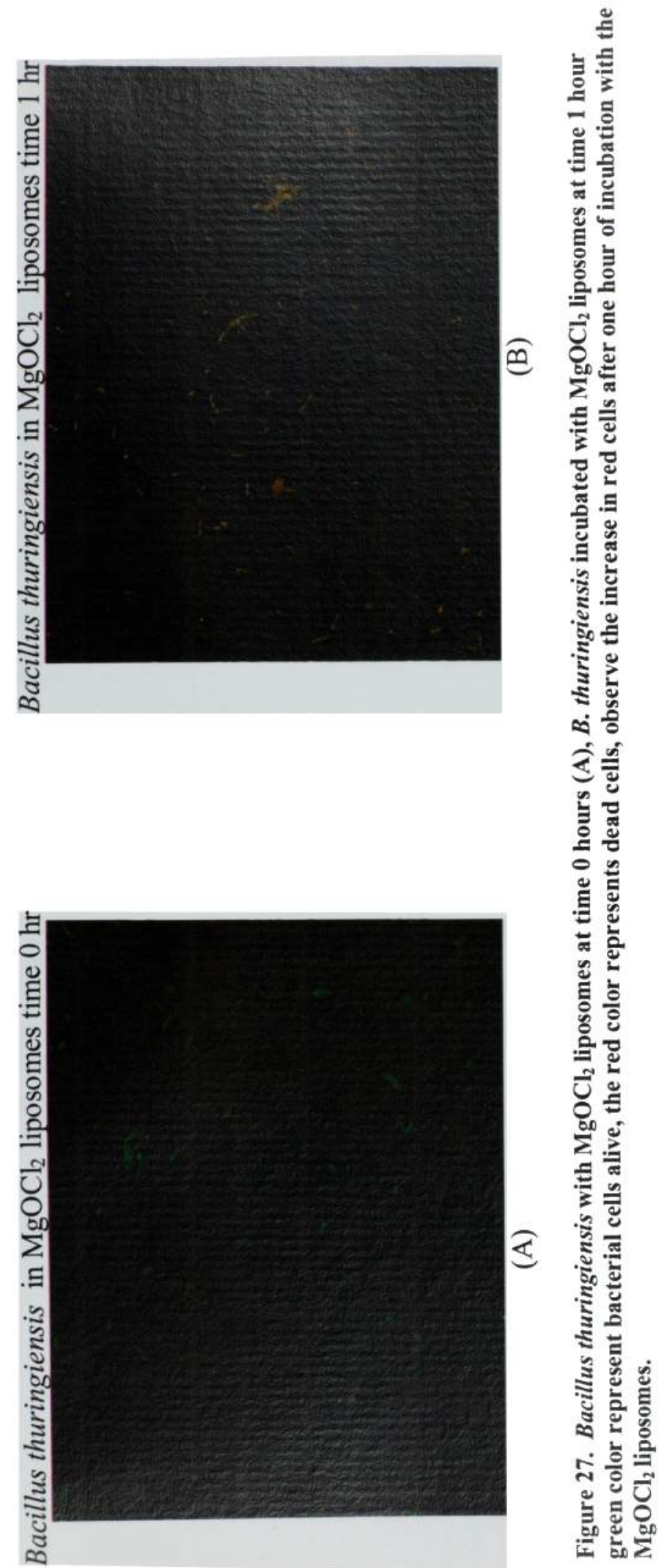

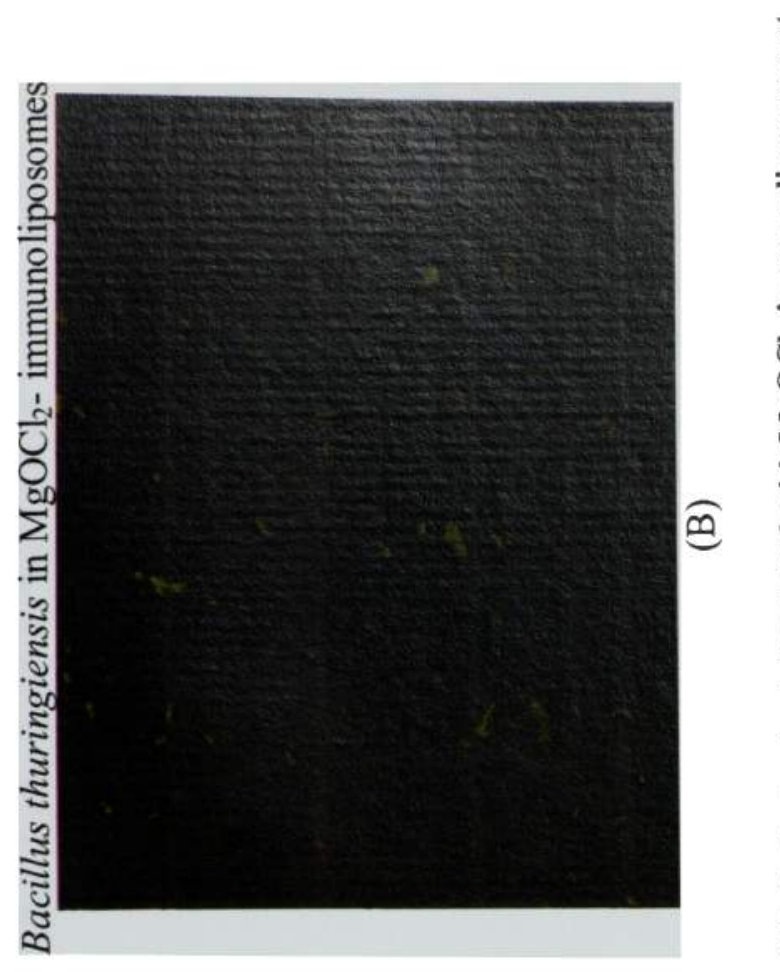

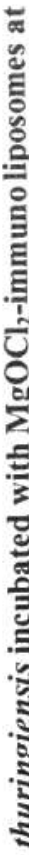

这

릴 잉
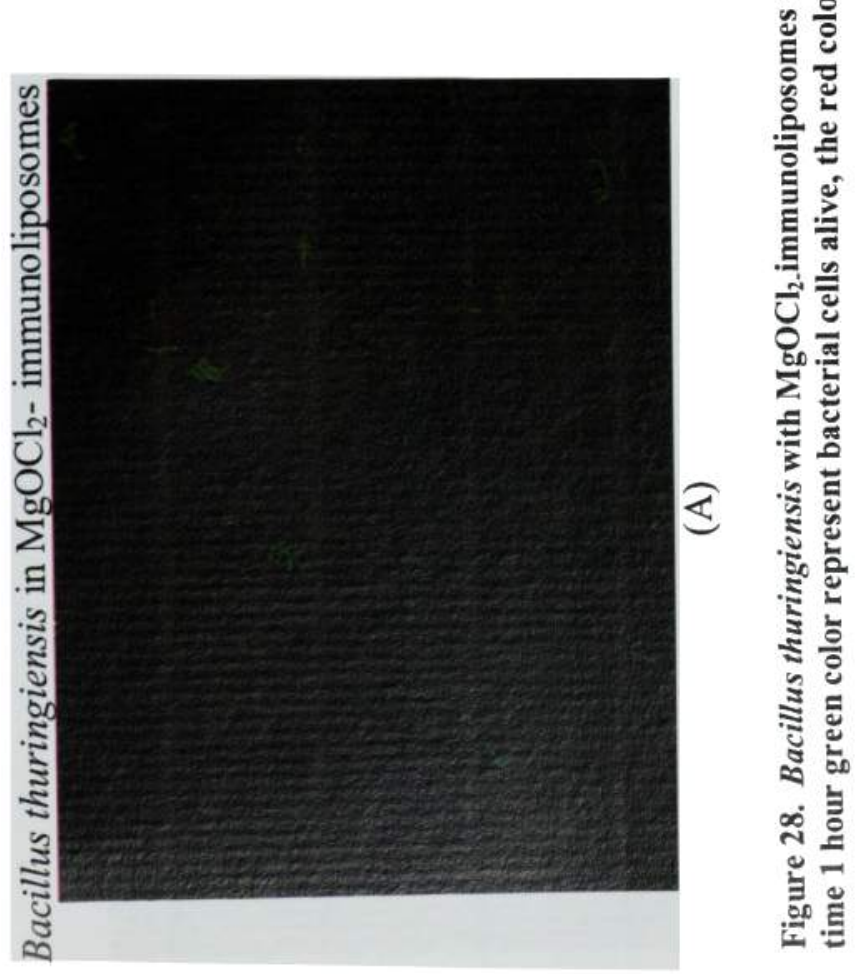

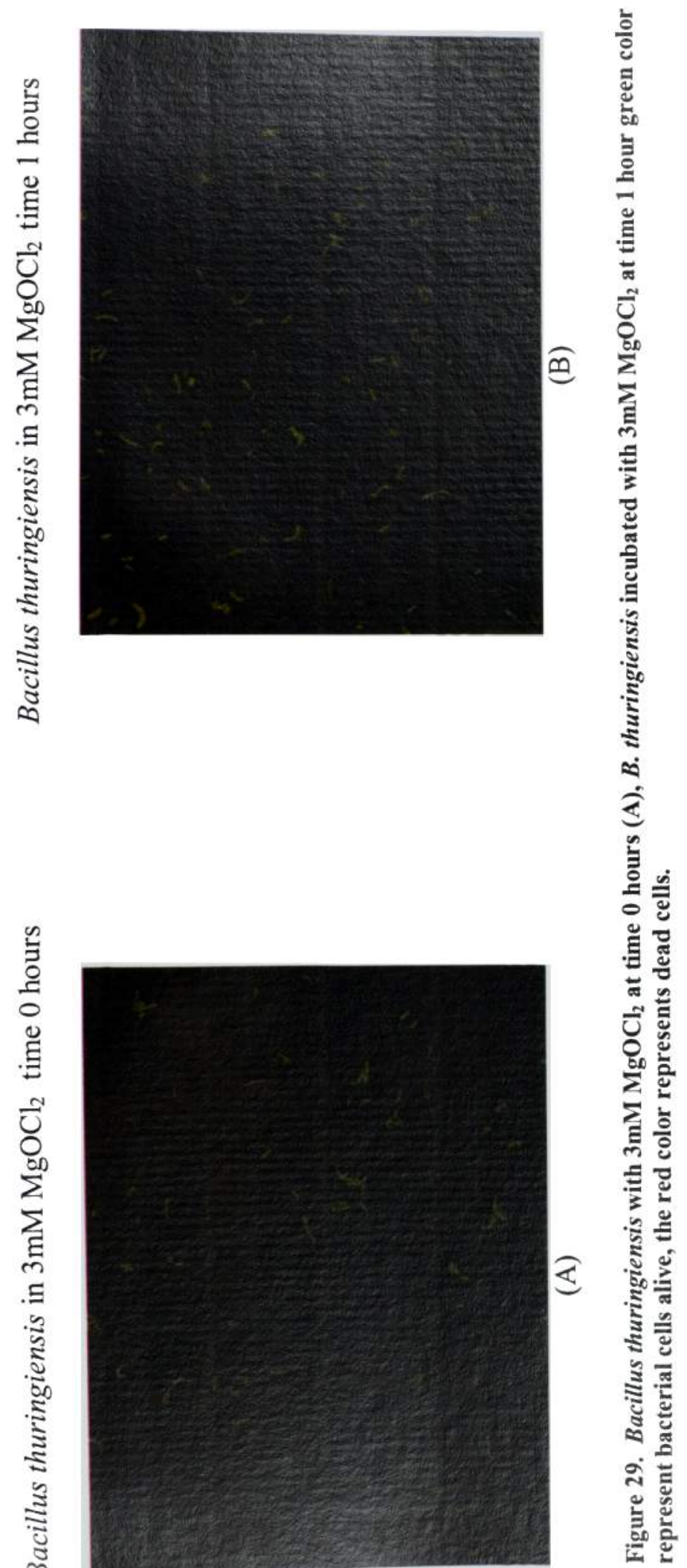